\title{
Algunos problemas historiográficos en torno a los libros del Antiguo Testamento y la investigación moderna (nuevas aportaciones)
}

\section{Some historiographic problems about Old Testament's texts and the modern investigation (new contributions)}

\author{
J.M. BLÁZqueZ MaRTíneZ \\ Real Academia de la Historia. Madrid \\ J. CABRERo PIQUeRo \\ Universidad Nacional de Educación a Distancia. Madrid
}

\begin{abstract}
RESUMEN
ABSTRACT

En este artículo se examinan una serie de trabajos, de diferentes autores, publicados en 2003 bajo la dirección de W.G. Devery

$S$. Gittin en una obra de conjunto: Symbiosis, Symbolism and the Power of the Past. Canaan, Ancient Israel and Their Neighbors from the Late Bronce Age Through Roman Palestina. Estos trabajos complementan las tesis de Finkelstein y de Liverani, editadas ya en esta revista.

Se tratan los siguientes problemas: El reino de Salomón; las provincias de

Salomón; el reino patromonial; el asentamiento; la monarquía unida; el impacto de las invasiones asirias; Yahweh, El y la familia astral divina; Ios dioses en Israel; los cultos israelitas y filisteos; el origen fenicio de los cultos cananeos; la relación entre el Egeo y el Oriente; la naturaleza del culto fenicio, sus símbolos y pervivencia; ; la comparación con el culto de Judá; el culto de Astarté en

Chipre; el Éxodo y la ocupación de

Palestina; También se examinan las teorías propuestas sobre el primitivo

In this article we a series of works, from different authors, published in 2003 under the direction of W.G. Dever and S. Gittin in a group work: Symbiosis, Symbolism and the Power of the Past. Canaan, Ancient Israel and Their Neighbors from the Brass Beats Age Through Roman Palestine. These articles complete the theses of Finkelstein and of Liverani, commented in this journal. They are the following problems: Salomón's Kingdom; Salomón's counties; the Patrimonial Kingdom; the settlement; the united monarchy; the impact of the Assyrian invasions; Yahweh, El and the divine astral family; the goddess of Israel; the Israel rites and Philistines; the phoenician source of Palestinian cults; the relationship between the Aegean and the East; the nature of the phoenician cults, their symbols and prevalence; the comparison with the cult of Judah; the cult of Astarte in Cyprus; the Exodus and the occupation of Palestine; examining the proposal theories about the primitive Israel.
\end{abstract}

Israel. 
PALABRAS CLAVE:

Israel, Palestina, Judá, Biblia, Reino Unido, Éxodo, Religión Fenicia, Moisés, Patriarcas, Jueces, Yahweh, El, Aserah, Astarté, Pentateuco.
KEYWORDS:

Israel, Palestine, Judah, Bible, United Monarchy, Exodus, Phoenician Cults, Moses, Patriarches, Judges, Yahweh, El, Aserah, Astarte, Pentateuco.

En este trabajo vamos a continuar la serie ya iniciada en trabajos anteriores ${ }^{1}$ en los que venimos revisando la historicidad de algunos libros del Antiguo Testamento, tema candente en la investigación de los últimos años.

En los trabajos anteriores comentamos los libros de Finkelstein², arqueólogo israelita de reconocido prestigio internacional del Instituto Nadler de Arqueología de la Universidad de Tel Aviv, y Silberman, director del Centro para la Arqueología y la Herencia de Bélgica; y el de Liverani ${ }^{3}$, conocido historiador del Oriente Antiguo que desarrolla su trabajo en la Universidad de Roma.

En el presente trabajo continuaremos la serie de aportaciones examinando dos nuevos estudios de extraordinaria importancia. El primero de ellos es un congreso del W.F. Albright Institute of Arhaeological Research y de la American Schools of Oriental Research en mayo del año 2000, celebrado en Jerusalem y que fue editado por W.G. Dever y S. Gitin4; y el de W.G. Dever ${ }^{5}$.

Del simposio vamos a comentar algunas comunicaciones que interesan directamente a la historia más antigua de Israel y hemos procurado sintetizar el pensamiento de los autores lo más exhaustivamente posible.

L.E. Stager ${ }^{6}$, profesor del Departamento de Lenguas y Civilizaciones del Próximo Oriente de la Universidad de Harvard, estudia el reino de Salomón y empieza

1 Blazquez, J. M., Cabrero, J. 2004: «La arqueología israelita y la historicidad de los libros del Antiguo Testamento», en Boletín de la Asociación Española de Orientalistas, pp. 17-57. Edit. Universidad Autónoma de Madrid. Id., 2005: «La historicidad de los relatos del Antiguo Testamento según la moderna historiografía», en Boletín de la Asociación Española de Orientalistas, pp. 23-73. Edit. Universidad Autónoma de Madrid. Este mismo tema lo hemos tratado también en: BLAZQUEZ, J. M., CABRERO, J. 2004: «Más mito que historia. Nuevas investigaciones sobre la Biblia», en La Aventura de la Historia, 72, Octubre, pp. 92-96. Id. 2005, «La historicidad de los libros del Antiguo Testamento a la luz de las nuevas aportaciones de la arqueología», en Vestnik Drevnej Istorii 5, Moscú (en ruso) (en prensa).

2 Finkelstein, I, Silberman, N. A. 2002: The Bible Unearthed. Archaeology's New Vision of Ancient Israel and the Origin of Its Sacred Texts, Edit. The Free Press, Nueva York, con traducción española La Biblia desenterrada: una nueva visión arqueológica del Antiguo Israel y de los orígenes de sus textos sagrados. Edit Siglo XXI, Madrid 2003.

3 Liverani, M. 2003: Oltre la Bibia. Storia antica di Israel. Edit. Laterza, Bari, con traducción española, Más allá de la Biblia. Edit. Crítica, Barcelona, 2004.

4 Dever W. G., Gitin S. (eds) 2003: Symbiosis, Symbolism and the Power of the Past. Canaan, Ancient Israel and Their Neighbors from the Late Bronce Age Through Roman Palestina: Proceedings of the Centennial Symposium W.F. Albright Institute of Arhaeological Research y de la American Schools of Oriental Research. Edit. Eisenbrauns, Indiana.

5 DeVER, W. G. 2003: Who where the Israelitas and where did they come from? Edit. Wm B. Erdmans Publishing Company, Cambridge. Para el presente trabajo hemos utilizado la edición francesa: Aux origenes d'Israël: quand la Bible dit vrai. Edit. Bayard, París 2005.

6 Stager, L. E. 2003: «The Patrimonial Kingdom of Salomon», en Dever W. G., Gitin S. (eds) 2003, op. Cit., 63-72. 
recogiendo las teorías de unos pocos arqueólogos de la Universidad de Tel Aviv, I. Finkelstein, D. Ussishkin y Zeev Herzog, que han intentado desplazar la cultura material del s. $x$ a.C., colocándola un siglo después en el reino del norte de Israel. El reino de Judá no existió como estado hasta mucho después, hasta el último cuarto del s. vill a.C., durante el reino de Ezequías (727-698 a.C.). Jerusalem, capital de una inexistente monarquía unida, hasta el reinado de Ezequías era una simple aldea. Por otro lado, T. Thompson y N. Lemches, de la Universidad de Copenhague, hicieron una revisión radical. Según estos investigadores, la Biblia hebrea es totalmente irrelevante para conocer aspectos de la historia política y cultural de Israel durante la Edad del Hierro, dado que este texto fue escrito en época helenística. Thompson escribe que las historias de la Edad de Oro de la monarquía unida reflejan la fantasía y ambiciones de Jerusalem de tiempos de los Macabeos. David (1044-965 a.C.) y Salomón (965-908 a.C.) tienen caracteres ficticios acuñados después de Juan Hicarnio (134-94 a.C.) y de Alejandro Magno respectivamente. Piensa L.E. Stager que, como historiadores, estamos obligados a tomar en serio la intencionalidad de muchos de los escritores bíblicos que se refieren al pasado. Si los investigadores bucean en las fuentes, bíblicas, arqueológicas, y en las inscripciones, convencidos de que el periodo de la monarquía unida es una completa fantasía, y de que sus reyes no han existido, eliminan algunas evidencias, como la lista de los oficiales de Salomón y las provincias de su reino, un documento que gran número de los biblistas han considerado en todo o en parte auténtico. Fuentes extrabíblicas, como la estela de Tell Dan ${ }^{7}$ mencionan la «Casa de David», con referencia al reino de Judá.

Pasa el profesor de Harvard a estudiar las relaciones del faraón Shishak y Salomón, examinando la lista de Egipto y los listados de los archivos de Jerusalem, que se fecharían después de Salomón, que pertenecen a los tiempos de Shishak o de Sheshonq, y que refieren las campañas militares contra Israel en torno al 925 a.C. según 1 Re 15.25 y $2 \mathrm{Cr} 12$; la invasión tuvo lugar el año 5 del reinado de Roboam (928-907 a.C.), que pagó tributo al faraón egipcio entregando los tesoros del templo y del palacio real lo que libró a Jerusalem de la destrucción. Se puede conocer la lista de las ciudades existentes pocos años antes de la destrucción de Shishak que coincidió con los años del reinado de Salomón, de las destrucciones sincrónicas en las ciudades excavadas mencionadas en la lista de Shishak, recordada en el templo de Amón en Karnak, donde aparecen los nombres de las fortalezas y de las ciudades palestinas. El problema, según L. Stager, estriba en que hay muchos lugares con niveles de destrucción sincrónica, en el periodo que va del 1000 al 840 a.C., algo que los arqueólogos que aceptan la cronología tradicional, podría atribuir a Shishak, s. x a.C. Finkelstein y otros pocos incluyendo a Na'aman

7 Tres fragmentos de basalto encontrados en 1993 y 1994 por Avraham Briran, en la actualidad en el Israel Museum de Jerusalem, fechados entre los siglos IX y VII a.C. Vid. AVRAHAM, B y NEVEH, J. 1994: «An Aramaic Stele Fragment from Tel Dan», en Israel Exploration Journal 43, 81-98; id. 1995 «The Tel Dan Inscripcion. A New Fragment» en Israel Exploration Journal 45, 1-18. En la línea 9 del fragmento A se lee L. BYTDWD. WS̆M. [..., texto interpretado como «casa de David». 
lo atribuyen a robos del jefe arameo Haza'el en torno al 840 a.C., lo que tradicionalmente se considera una destrucción fechada en torno al año 1000-980 a.C. Finkelstein la atribuye a Shishak en torno al 925 a.C. Arad XII representa el asentamiento conocido como el Gran Arad en la lista de Shishak, o una fortaleza en el Negev. Varios nombres de la lista de Shishak han sido borrados o están borrosos. No se mencionan en la lista Gezer ni otras ciudades de Judá. Los nombres de BethShean y el valle del Jezreel parecen más claros que los nombres de Megiddo, Taanach, Shunem, Beth-Shean y Rehob. En Meggido, Shishak dejó una estela como señal de su victoria. La arqueología ha demostrado que Meggido VIA y Meggido VA-IVB fueron grandes ciudades y ambas destruidas en parte por una conflagración general. Tradicionalmente, la destrucción parcial de Meggido VA-IVB se atribuye a Shishak. Meggido poseía magníficos edificios de sillares monumentales, con palacios y otras construcciones públicas, seis puertas de seis cámaras, semejantes a las puertas de Hazor y de Gezer. Finkelstein y otros arqueólogos rebajan la fecha de destrucción de la ciudad y, para Meggido VIA dan la cronología de 625 a.C., y el final de ella, Meggido VA-IVB, lo hacen coincidir con la muerte de Jezreel.

Recientemente Finkelstein, Zimhoni y Kafri escriben que Meggido VIB, que tiene cerámica bicónica filistea y pithoi de borde en el cuello, podían datarse en el s. XI a.C., mientras que el estrato VIA podía colocarse en el s. X a.C. Según Ben-Tor, la mayoría de las cerámicas presentan las características tipológicas locales de finales de la Edad del Bronce. El segundo grupo comprende cerámicas que son claramente fenicias. El tercer grupo está formado por cerámicas filisteas, parecidas a los vasos que se han hallado al sur de Israel y en la llanura costera. Si se hallara un palacio Bithilani, similar a los de Meggido VA-IVB en una ciudad siria, con más probabilidad se encontraría un templo en las proximidades. Esto es algo que no sucede ni en Meggido ni en ninguna otra capital provincial en el s. x a.C. La razón es muy sencilla: el único lugar, durante la monarquía unida, que tenía palacio y templo, fue la capital, Jerusalem, el centro simbólico ritual regio, del reino y del cosmos.

La ciudad regia ritual no proporcionaba el lugar en el que diariamente se hacían rituales, se celebraban las festividades de las estaciones y otras ceremonias, y podía ser elegida para asegurar la participación de lo divino y de lo humano en los asuntos divinos. Piensa E. Stager que la Jerusalem anterior al s. VIII a.C., era una ciudad muy pequeña, de no más de $12 \mathrm{Ha}$, con una población de unos 3000 habitantes. No podía calificarse de centro urbano, como centro simbólico, la capital del cosmos, sería la encarnación de lo sagrado en la sociedad.

Con el descubrimiento del templo de 'Am Dara en Siria, parece claro que el templo de Salomón, tal y como lo describe el libro primeros de los Reyes ${ }^{8}$, no es, ni una narración anacrónica basada en un arquetipo de templo posterior, ni una creación literaria.

8 1Re 6-7. 


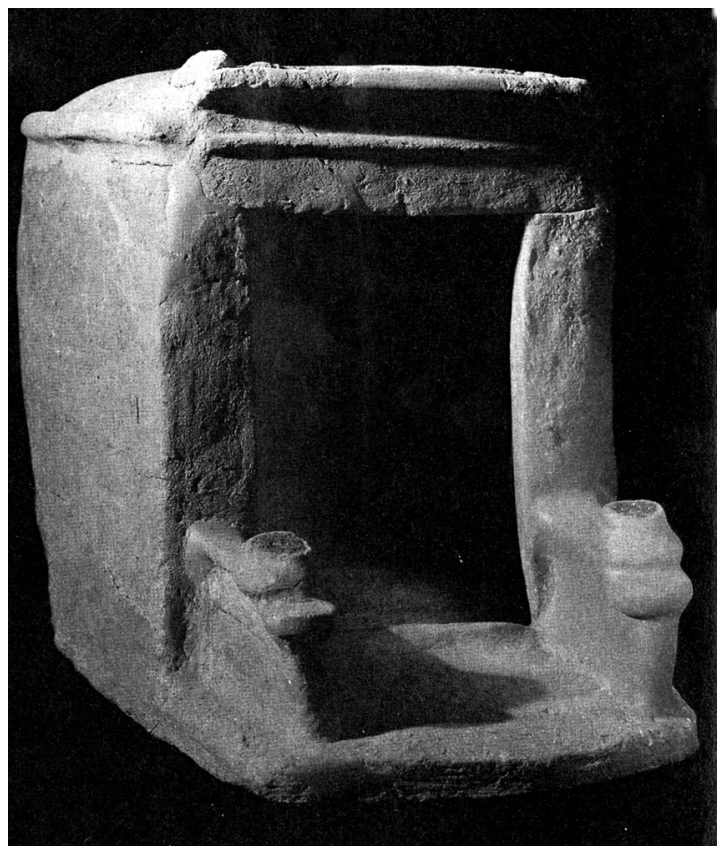

Figura 1: Terracota representando a un templo fenicio procedente del Líbano. Museo Arqueológico Nacional de Beirut.

El plano, las dimensiones, los detalles arquitectónicos del templo de Salomón, se adaptan completamente a las tradiciones de la arquitectura sagrada conocida en Siria y, probablemente, en Fenicia, desde el s. $x$ al vilI a.C. El complejo templo-palacio de Jerusalem no excluye instalaciones más pequeñas de culto. Ejemplos idénticos se han hallado dentro de la puerta de Meggido VA-IVB, y en una estructura de culto en Taanach IIB con habitaciones llenas de altares de incienso con mesas de culto y con cuencos llenos de astrágalos de ovejas y de cabras. El nivel de destrucción de Taanach, solamente podía ser atribuido a Shishak, pues no hay cerámica filistea en el lugar. Los otros niveles de destrucción son anteriores. El estrato IB fue destruido, según la cronología tradicional, en torno al 1100 a.C. Finkelstein ha comparado Meggido VIA, con cerámica filistea, con Taanach IB, con cerámica prefilistea. Ha rebajado la fecha de destrucción de ambas ciudades a los tiempos de Shishak. lo que es verdadero para Meggido y para Taanach, es también verdad para Beth-Shean. En Rehob citado igualmente en la lista de Shishak, hay tres niveles de conflagración, los estratos VII-V, uno de los cuales es atribuido con seguridad a Shishak.

Gezer VIII, con una puerta de seis cámaras y edificios administrativos próximos, sufrió destrucciones por el mismo tiempo. Lo mismo se documenta en Yoqne'am. Hazor X-IX puede añadirse a la lista de ciudades que sufrieron una mayor transformación en el s. $x$ a.C. La lista de Shishak menciona asentamientos del de- 
sierto de Negev. Principalmente son fortalezas, conocidas como hagarim. En respuesta a la amenaza enemiga se estableció un sistema de fortalezas en el interland de Negev, durante el s. x a.C., aproximadamente entre los años 975 y 925 a.C. Después de la campaña de Shishak y de la división de la monarquía unida, el borde de Judá se contrajo al Valle de Beersheba.

L.E. Stager, apoyándose en la cronología de las actividades de Shishak en el valle de Jezreel y en el interland de Negev, en relación con los lugares contemporáneos del siglo x a.C., no tiene reparos en involucrar la noticia de 1 Re 9.15, en la que se afirma que Salomón había reclutado trabajadores para construir el templo, el palacio, el Mil-lo, y la muralla de Jerusalem, de Hazor, de Meggido y de Gezer. Puntualiza el profesor de Harvard que la comparación que Yadin hizo de las puertas de seis cámaras de Hazor, Meggido y Geza, y la cronología que proponía, siglo $x$ a.C., ha aguantado la prueba del tiempo. El hecho de que en 1 Re 9.15 se omita la noticia de un ejemplo de la filistea Ashdod del siglo $x$ a.C., y otro de Laquish del siglo Ix a.C., vuelve todo más probable.

\section{LAS PROVINCIAS DE SALOMÓN}

La lista de archivo de $1 \operatorname{Re} 4$, en todo o en parte ha sido atribuida al reinado de Salomón por excelentes historiadores de la Biblia. Los biblistas, que niegan la existencia de la monarquía unida, tienen dificultad en aceptar tal atribución. Esta lista cae de plano en el estado patrimonial de Weber, tipo ideal basado en la comparación de culturas. 1 Re 4 afirma:

«'Reinó, pues, el rey Salomón sobre todo Israel. ${ }^{2} Y$ estos fueron los jefes que tuvo: Azarías hijo del sacerdote Sadoc; ${ }^{3}$ Elihoref y Ahías, hijos de Sisa, secretarios; Josafat hijo de Ahilud, canciller; ${ }^{4}$ Benaía hijo de Joiada sobre el ejército; Sadoc y Abiatar, los sacerdotes; ${ }^{5}$ Azarías hijo de Natán, sobre los gobernadores; Zabud hijo de Natán, ministro principal y amigo del rey; ${ }^{6}$ Ahisar, mayordomo; y Adoniram hijo de Abda, sobre el tributo. ${ }^{7}$ Tenía Salomón doce gobernadores sobre todo Israel, los cuales mantenían al rey y a su casa. Cada uno de ellos estaba obligado a abastecerlo por un mes en el año. ${ }^{8}$ Y estos son los nombres de ellos: el hijo de Hur en el monte de Efraín; ${ }^{9}$ el hijo de Decar en Macaz, en Saalbim, en Bet-semes, en Elón y en Bet-hanán; ${ }^{10} \mathrm{el} \mathrm{hijo} \mathrm{de} \mathrm{Hesed} \mathrm{en} \mathrm{Arubot;} \mathrm{éste} \mathrm{tenía} \mathrm{también} \mathrm{a} \mathrm{Soco} \mathrm{y} \mathrm{toda} \mathrm{la} \mathrm{tie-}$ rra de Hefer; ${ }^{11}$ el hijo de Abinadab en todos los territorios de Dor; éste tenía por mujer a Tafat hija de Salomón; ${ }^{12}$ Baana hijo de Ahilud en Taanac y Meguido, en toda Bet-seán, que está cerca de Saretán, más abajo de Jezreel, desde Bet-seán hasta Abel-mehola, y hasta el otro lado de Jocmeam; ${ }^{13} \mathrm{el}$ hijo de Geber en Ramot de Galaad; éste tenía también las ciudades de Jair hijo de Manasés, las cuales estaban en Galaad; tenía también la provincia de Argob que estaba en Basán, sesenta grandes ciudades con muro y cerraduras de bronce; ${ }^{14}$ Ahinadab hijo de Iddo en Mahanaim; ${ }^{15}$ Ahimaas en Neftalí; éste tomó también por mujer a Basemat hija de Salomón. ${ }^{16}$ Baana hijo de Husai, en Aser y en Alot; ${ }^{17}$ Josafat hijo de Parúa, en Isacar; ${ }^{18}$ Simei hijo de Ela, en Benjamín; ${ }^{19}$ Geber hijo de Uri, en la tierra de Galaad, la tierra de Sehón rey de los amorreos y de Og rey de Basán; éste era el único gobernador en aquella tierra. ${ }^{20}$ Judá e Israel eran muchos, como la arena que está 
junto al mar en multitud, comiendo, bebiendo y alegrándose. ${ }^{21}$ Y Salomón señoreaba sobre todos los reinos desde el Éufrates hasta la tierra de los filisteos y el límite con Egipto; y traían presentes, y sirvieron a Salomón todos los días que vivió. ${ }^{22}$ Y la provisión de Salomón para cada día era de treinta coros de flor de harina, sesenta coros de harina, ${ }^{23}$ diez bueyes gordos, veinte bueyes de pasto y cien ovejas; sin los ciervos, gacelas, corzos y aves gordas. ${ }^{24}$ Porque él señoreaba en toda la región al oeste del Éufrates, desde Tifsa hasta Gaza, sobre todos los reyes al oeste del Eufrates; y tuvo paz por todos lados alrededor. ${ }^{25}$ Y Judá e Israel vivían seguros, cada uno debajo de su parra y debajo de su higuera, desde Dan hasta Beerseba, todos los días de Salomón. ${ }^{26}$ Además de esto, Salomón tenía cuarenta mil caballos en sus caballerizas para sus carros, y doce mil jinetes. ${ }^{27} Y$ estos gobernadores mantenían al rey Salomón, y a todos los que a la mesa del rey Salomón venían, cada uno un mes, y hacían que nada faltase. ${ }^{28} \mathrm{Hacían}$ también traer cebada y paja para los caballos y para las bestias de carga, al lugar donde él estaba, cada uno conforme al turno que tenía. ${ }^{29}$ Y Dios dio a Salomón sabiduría y prudencia muy grandes, y anchura de corazón como la arena que está a la orilla del mar. ${ }^{30}$ Era mayor la sabiduría de Salomón que la de todos los orientales, y que toda la sabiduría de los egipcios. ${ }^{31}$ Aun fue más sabio que todos los hombres, más que Etán ezraíta, y que Hemán, Calcol y Darda, hijos de Mahol; y fue conocido entre todas las naciones de alrededor. ${ }^{32} \mathrm{Y}$ compuso tres mil proverbios, y sus cantares fueron mil cinco. ${ }^{33}$ También disertó sobre los árboles, desde el cedro del Líbano hasta el hisopo que nace en la pared. Asimismo disertó sobre los animales, sobre las aves, sobre los reptiles y sobre los peces. ${ }^{34} Y$ para oír la sabiduría de Salomón venían de todos los pueblos y de todos los reyes de la tierra, adonde había llegado la fama de su sabiduría»?.

El autor bíblico da la lista de los 12 distritos o provincias. Muchos de estos centros provinciales, como Taanach, Meggido, Beth-Sean, Jezreel, Dor, Beeth-Shemesh y Yokne'an. Antes de la campaña de Shishak del 925 a.C., cada lugar había sufrido una radical transformación y se había convertido en un centro regio con edificios monumentales. Muchas de estas transformaciones son contemporáneas del reinado de Salomón.

Las recientes excavaciones de Beth-Shemesh han demostrado una mayor transformación del asentamiento desde el estrato III al II. Fue la posterior capital provincial bien planeada de la segunda provincia de Salomón (1Re. 4.9), con el palacio del gobernador, con fortificaciones, con reservoir bajo tierra, de una capacidad de unos 795.000 litros para abastecer de agua a toda la población. Esta instalación de agua es un buen ejemplo de un proyecto hidrográfico regio, conocido como 'Swh en la estela Mesha o en la piedra Moabita. La cerámica de Beth-Shemesh II es contemporánea de la de Arad XII y se fecha en el siglo x a.C. La capital de la tercera provincia de Salomón, Arubboth (1Re. 4.10), se ha identificado con Khirbet el-Hamam, en Samaría, y la tierra de Hepher con su centro en Tell Muhaffar. La tercera provincia estaría en el territorio de Manases. Una vez más se demuestra que estas provincias, con excepción de los territorios recientemente conquistados,

9 Los textos bíblicos del presente trabajo han sido tomados de la traducción de la Biblia realizada por Cipriano Valera y Casiodoro Reina. 
como Dor en la cuarta provincia y el Valle de Jezreel en la quinta provincia, corresponden a los límites de los viejos territorios tribales.

L. E. Stager recoge la opinión de Wright según la cual la reorganización del campo hecha por Salomón, ha tenido efecto beneficioso para reponer las lealtades familiares anteriores, con otras regias, y de distribuir por igual las cargas de las tasas de cada provincia, de acuerdo a las regiones. Por lo tanto, a cada una de las doce ciudades se les pedía suministrar anualmente los gastos de manutención de un mes, para sufragar así los gastos del monarca y costear el ritual en Jerusalem.

Que tal sistema burocrático jamás ha existido en el antiguo Israel, y que el clan anterior a la monarquía y el reparto tribal permaneció intacto, están, parcialmente, demostrados por los ostraca de Samaria, datados en el siglo vIII a.C., hallados en el norte de la capital, que mencionan la recolección de tasas familiares de aceite de oliva y de vino, que fueron ofrecidas al rey por los notables o por los jefes del clan. Estos ostraca proceden del territorio tribal de Manases, y representan varios distritos del clan en el territorio, todavía intacto, de la tercera provincia, un siglo o siglo y medio después del establecimiento de la monarquía. Recoge el profesor de Harvard la noción de Wright y de otros historiadores bíblicos, según la cual la monarquía israelita fue una especie de institución de origen extranjero, cananeo, injertada en una sociedad de base familiar, igualitaria, que con el paso del tiempo llegó a ser una sociedad dividida por una élite, opresiva y explotadora. Un esquema común hace a las sociedades ir a través de una línea de progresión, desde el clan a la tribu, a la jefatura y, finalmente, al estado, en el que las divisiones de clase y de patronazgo desplazan la relación de parentesco.

La aproximación objetiva a los restos materiales señala una variedad de antesalas cuantitativas para cada escalón de la evolución. En el caso de Israel se ha entendido que los israelitas no tenían el concepto de estratificación social a través de líneas de clases y que no existía el concepto de clase. Las relaciones verticales de superior con el inferior fueron de un orden diferente y más abigarradas que el concepto de clase permitía.

\section{EL REINO PATRIMONIAL}

De los tres tipos de autoridad de Weber: carismático, tradicional y racional-legal, el tipo tradicional expresado en términos de un dominio patrimonial parece el más apropiado para los símbolos primarios de la cosmovisión israelita. La analogía creativa del cosmos, entre los finito y lo infinito, se expresa a través de los símbolos de la familia. La cosmovisión israelita es un cosmos basado en una serie de familias. En la base de esta jerarquía de orden está la casa ancestral o patriarcal, la casa del padre. Las huellas físicas de este símbolo se pueden hallar en el trazado de las casas con columnas y sus grupos de la Edad del Hierro. A nivel de estado o 
reino tribal, el rey funcionaba como un pater familias, del que los súbditos esperaban protección y ayuda. El rey preside su casa, que comprende familias y casas. A este nivel de simbolismo, los arameos y los moabitas en Tell Dan y en la estela de Mesha, aluden, al referirse al reino del norte de Judá, a la casa de David, al igual que los asirios se refieren al reino del norte, como la casa de Omri (882-871 a.C.). L.E. Stager es de la opinión que estas dos citas, fechadas en el s. IX a.C., relativas al reino de Judá, son bastante expresivas en sí mismas para demostrar que Judá fue un pleno estado a los ojos de sus vecinos antes de finales del siglo VIII a.C. El rey no representa la cumbre de la autoridad en la cosmovisión israelita. Esta posición la ocupa Yahweh, que reina como supremo señor patrimonial, autoridad suprema sobre el rey y sobre los hijos de Israel, vinculados a él por un pacto como su pariente.

L.E. Stager concluye en su exposición, que hemos seguido detenidamente, que hay una gran cantidad de evidencias sacadas de las fuentes bíblicas, de las arqueológicas, inscripciones y teoría política que apoyan la noción de la cosmovisión israelita, en la que los miembros de la comunidad participan en la transformación desde una confederación tribal a un reino tribal en el siglo x a.C. Con la cronología muy ajustada establecida por las fuentes egipcias referentes a las campañas de Shishak en Palestina en el año 925 a.C., la adecuada composición de que el vínculo de estado a través de las tipologías, de los símbolos de las fuentes bíblicas y arqueológicas, y los restos arqueológicos de estos símbolos, permiten concluir que el reino unido de Israel ya existía en el s. x a.C. y que floreció después de su subdivisión.

I. Finkelstein ${ }^{10}$ estudia el paso de la sociedad estado al estado, con la dinámica política en los siglos X-IX a.C. Comienza el conocido arqueólogo israelita, recordando que se suele aceptar que el sistema egipcio-cananeo de final de la Edad del Bronce de ciudades-estado terminó en la segunda mitad del siglo XII a.C. Se pregunta qué sucedió después. ¿Vino el colapso de la Canaán del segundo milenio? Con anterioridad el sistema urbano de la primitiva Edad del Bronce y del Bronce Medio había sufrido mayores sacudidas y se recuperó después de un corto periodo de tiempo. Se continúa preguntando Finkelstein si conocemos cuándo y cómo el sistema de ciudad-estado acabó en Canaán.

Al comienzo de la investigación las líneas no fueron deducidas de la arqueología, sino de acuerdo con dos consideraciones históricas: la narración bíblica de la conquista de Canaan, y el subsiguiente asentamiento israelita; y los textos egipcios alusivos a la invasión de los pueblos del Mar. En teoría se podía argüir que la cultura de Canaán, podía haber sido recuperada por las migraciones de los Pueblos del Mar. El año 1200 a.C., podía ser el punto crucial en la historia de Canaán. La investigación arqueológica ha demostrado con claridad que Canaán no fue borra-

10 Finkelstein, I. 2003: "City States to States: Polity Dynamics in the 10th-9th Centuries B.C.», en DEVER W. G., Gitin S. (eds) 2003, op. Cit., 75-83. 
da por una campaña militar y el primitivo Israel y sus vecinos salen de una población autóctona, del sur del Levante.

La idea de ciudades-estado de Canaán arrasados, de la desaparición de la población indígena y de la emergencia del joven Israel de las ruinas, ha desaparecido. Se acepta, generalmente, entre los investigadores, que las narraciones bíblicas no se pusieron por escrito antes del siglo vII a.C. Aunque los textos conservan algunos materiales más antiguos, en la mayoría de los casos están, además, retocados, porque el escritor que redactó el Deuteronomio, los adaptó a su ideología, y las presentó de tal manera, que podían ser utilizados para adelantar su objetivo político. Una lectura de la descripción bíblica de la conquista debe ser consciente de que está redactada con la ideología del final de la monarquía de Judá, no en la realidad de la Edad del Bronce Final, o de la Edad del Bronce. La descripción de la conquista de Galilea, que puede basarse en un auténtico cuento folklorístico, fue propuesta para demostrar que Judá fue el único heredero de los territorios del reino del norte. La lista de las ciudades que no fueron conquistadas, todas en el norte, no es más que una fábula teológica del fracaso del reino del norte, para erradicar la cultura cananea. La gran conquista de David es una construcción ideológica que declara la aparición del último y nuevo David (Josías, 639-609 a.C.) y de la agenda para la reconstrucción de una mítica Edad de Oro.

El arqueólogo israelita considera que no tiene ya actualidad la reconstrucción del final de la Edad del Bronce Cananeo que se hizo en los años 1920 y 1930. Hay que plantear el problema a una nueva luz.

Al estudiar el final de la Edad del Bronce cananeo se llega a la conclusión de que los hallazgos en lugares como Meggido, Beth-Shean, Laquish y Ashdod, reflejan asentamientos de los principales centros, ciudades-estados, puertos y fortalezas egipcias. Recientes descubrimientos de campo indican que la pintura es diferente. Las excavaciones de Tell Menonrah en el valle de Beth-Shean, de Tell el-Wawiyat y de 'Ein Zippori en la Baja Galilea, demuestran que el campo no sufrió daño alguno. Los lugares demuestran una continuidad geográfica y cultural durante la transición del Bronce Final-Hierro I. Los valles del norte estaban densamente poblados al final de la Edad del Bronce y Hierro I. No hay señales de una crisis mayor. En el Valle de Jezreel, en el número de asentamientos, en su situación y en su área de edificación no se detectan cambios en el paso de estos periodos. Lo mismo de documenta en el valle de Beth-Shean, al este.

Poco después de la destrucción, los principales centros fueron reocupados. El caso mejor conocido es Meggido. En el siglo XI a.C., después de un vacío de ocupación de pocas décadas, Meggido se reasienta en el estrato VIB. Fue una pobre y pequeña aldea a lo largo de unas décadas gradual e ininterrumpidamente se desarrolló con prosperidad en el estrato VIA, fechado en el siglo $x$ a.C.

La ciudad del estrato VIA es muy semejante a la del estrato VIIA, datado éste último en el siglo XII a.C. No es menos importante señalar que la siguiente ciudad 
de Meggido es totalmente diferente. La extensión de las dos ciudades (VIIA y VIA) es igual; ambas abarcan el tell superior de la terraza baja, un área de $11 \mathrm{Ha}$. La ciudad del Hierro II ocupaba sólo el tell superior. Ambas tenían un palacio al norte, próximo a la puerta. En el estrato $\mathrm{V}$ los palacios están situados en otra parte. La cerámica prueba una continuidad cultural. La cerámica del estrato $V$ sigue la tradición del Hierro II. Los objetos de bronce del estrato VIA son una continuidad de tradiciones de final de la Edad del Bronce. La cerámica del último suelo del templo, Migdal, prueba una continuidad en la función hasta la destrucción del estrato VIA.

Se ha debatido muy acaloradamente la identidad de los habitantes de esta ciudad. Algunos investigadores apuntan a poblaciones con características cananeas o filisteas en su cultura.

Para I. Finkelstein es muy dudoso que Meggido VIA fuera una ciudad cananea. Los habitantes, posiblemente, proceden de las aldeas próximas. Al parecer, Meggido VIA funcionaba como centro de una comunidad-estado controlando los territorios vecinos, pero se carece de fuentes. El análisis de los hallazgos no nos permiten una interpretación alternativa. Los hallazgos apuntan a una ciudad muy próspera, embarcada en un comercio a larga distancia, con claros indicios de estratificación social, situada en el centro de un territorio rural. Al menos el norte, que soportó una severa catástrofe en la mitad del siglo CII a.C., se rehizo de las cenizas a finales del siglo $\mathrm{xI}$ y a comienzos del siglo $\mathrm{x}$ a.C.

Meggido fue no sólo el eslabón en este nuevo Canaán. Existían otras ciudades parecidas, como Tell Kinneret, Tell Rehov en el valle del Jordán, Tell Dor y, probablemente, Tell Keisan, en la costa.

El Hierro I de Kinneret reemplazó al Hazor de finales de la Edad del Bronce como centro del valle superior del Jordán. Una ciudad bien fortificada, de unas 10 Ha de extensión, se desarrolló en Tell Kinneret en un corto periodo de tiempo. La ciudad no alcanzó nunca tal prosperidad como en el Hierro I.

Tell Rehov, una ciudad contemporánea de Meggido VIA, cubría toda la colina del tell superior y de la terraza baja, con una extensión de unas $10 \mathrm{Ha}$. Rehov fue la mayor ciudad estado al final de la Edad del Bronce. Fue la principal ciudad del Valle de Beth-Shean durante el Hierro, en este tiempo un establecimiento relativamente pequeño. De ello se puede deducir que la Rehov del Hierro I funcionaba como centro de un territorio que se extendía por Beth-Shean y por el Valle de Jezreel al este. Acco decayó a finales de la Edad del Bronce, pero Tell Keisan, probablemente la Achshaph del Bronce Final, continuaba próspera. Parece que era el principal centro de la llanura norte de la costa, con su puerto situado en Tell Abu Hawam. Su territorio comprendía, también, Acco al final del Bronce.

Dor era próspera en este tiempo. Tenía una extensión de 7-8 Ha. Sus habitantes comerciaban con Fenicia y con Chipre. El edificio monumental excavado al sur de la colina prueba la riqueza y la naturaleza urbana de la ciudad del Hierro I, 
que debió controlar la llanura costera de la cadena montañosa del Carmelo. Es posible que Dor sustituyera a la Gath del Bronce Final, como principal centro en esta región, pero los hallazgos del Hierro I, de Gath son tan escasos, que no podemos sacar conclusiones. Durante el Bronce Final y la transición al Hierro I, la región de Philistia conserva huellas de continuidad y de cambio.

Estudios recientes demuestran que la emigración de miles desde el oeste es altamente improbable y que la población de Philistia en el Hierro I tiene un importante componente local. Al parecer, una élite minoritaria dictaba los rasgos culturales a una población mezclada. Desde el punto de vista de la demografía territorial, los principales cambios fueron la total eliminación de la ciudad-estado del Bronce Final de Laquish y sus aldeas, La ascensión de Ekrom del Hierro I, el crecimiento significativo de las ciudades del centro y la disminución del sector rural.

La continuidad se deduce del desarrollo ininterrumpido de muchas aldeas, y del dominio continuado de Gaza, Ashkelon, Ashdod y Gath.

La mayoría de las principales ciudades-estado del Bronce Final Cananeo se recuperaron en el siglo XI a.C.; de hecho, sólo dos ciudades del Bronce Final en las tierras Bajas, Hazor y Laquish, fueron aniquiladas y reemplazadas por las ciudades vecinas, Kinneret en el norte y Ekrom en el sur. Un mayor cambio se documenta por este tiempo sólo en las montañas, donde hubo fuertes oleadas de asentamiento. Aún entonces, se desconoce bastante el status de los dos antiguos centros del Bronce Final, Jerusalem y Siquem. En el norte, la prosperidad del nuevo Canaán proviene de la estabilidad del sector rural y del intenso comercio con Fenicia, con Chipre y más lejos aún. Las ciudades del norte, probablemente, comerciaban con productos secundarios en los lugares, como hortalizas en las montañas, sirviendo como comunidades de transito para estos productos. Algunos pithoi en Dor proceden de las montañas. La actividad metalúrgica es bien patente en muchas de las principales ciudades de los valles de Jezreel y del Jordán. Al parecer el cobre procedía del sur. Se ha sugerido que el cobre del valle del Arabah remplazó al mineral chipriota después del hundimiento de la economía del Bronce Final en Wadi Feinan en el Hierro I.

El nuevo Canaán se colapsó. Destrucciones violentas se documentan en todos los principales centros. Toda la ciudad de Meggido fue abrasada, Kinneret no se recuperó. Aunque en este tiempo el hundimiento del sistema cananeo estaba llegando al final, el sector rural no se interrumpió. Los principales centros fueron arruinados al mismo tiempo. Finkelstein propone que para identificar a los destructores es necesario conocer la fecha de la destrucción. El arqueólogo israelita suguiere la fecha del siglo $x$ a.C., para Meggido, pues los análisis del radio-carbono para Meggido, Dor, Tell Hadar y Kinneret, todos apuntan a esa fecha.

Finkelstein presenta dos posibilidades para explicar la destrucción de los centros cananeos del norte en el siglo x a.C. Según la primera, el sistema de asentamiento expansivo en las montañas dañó a las ciudades de las tierras bajas. El ar- 
queólogo israelita no ve claro si la primitiva política seguida en las montañas fue motivo de destrucción en las ciudades-estado de las tierras bajas. Según la segunda posibilidad, el nuevo Canaán fue atacado por el faraón Sheshonq I en la segunda mitad del siglo $x$ a.C.

Rehov y Meggido se mencionan en la lista de Sheshonq I, y un fragmento de una estela de Sheshonq I se halló en Meggido, por desgracia en un estrato sin estratigrafía. Según esta hipótesis Egipto desencadenó en Canaán un ataque devastador. Egipto se retiró después de aniquilar el viejo sistema, creando un vacío que abrió el camino a los jefes de la región norte montañosa, para expansionarse a las tierras bajas y establecer un estado territorial multiétnico.

Finkelstein se plantea el problema porqué Sheshonq I destruyó estas ciudades si él pensaba continuar la dominación de Canaán, y porqué levantó una estela en una ciudad destruida. Las dos hipótesis son igualmente atractivas. El arqueólogo israelita se pregunta qué papel desempeñó la monarquía unida en esta historia. Finkelstein deduce que no existe evidencia arqueológica para una próspera monarquía unida, que se extendía a todo el territorio de Palestina, de la nueva interpretación que ha propuesto para los hallazgos del norte; de los palacios de Meggido y de otros estratos del siglo $x$ al Ix a.C., de los hallazgos fechados en el siglo $x$ a.C., hallados en Jerusalem; de los escasos hallazgos del siglo $x$ a.C., recogidos en las montañas de Judá, y de la postura general, que indica que los estados territoriales no emergieron antes del siglo Ix a.C. En la historia del Deuteronomio de carácter altamente teológico, no hay evidencia textual para sospechar la existencia de una monarquía unida.

La sola evidencia para una monarquía unida es el llamamiento del Deuteronomio a la memoria colectiva del pueblo de Judá en su tiempo, prometiendo el restablecimiento de una edad de oro pasada. Se puede mantener que en el siglo VII a.C., Judá conservaba una vaga memoria de que los fundadores de la dinastía davídica, mandaron sobre un territorio en las montañas, que fue más extenso que el tradicional territorio de la monarquía de Judá, y que su territorio incorporaba áreas que después fueron añadidas al reino del norte. La naturaleza de esta evidencia en Jerusalem y en el país montañoso al sur sugieren que hasta el siglo Ix a.C., el país montañoso del sur todavía representaba una típica formación semejante a Amarna. Para conocer en qué grado la caída del nuevo Canaán afectó al curso de la historia y el desarrollo cultural en el levante, es necesario observar el reino del norte de Israel. Judá no emergió como un estado hecho hasta el siglo VIII a.C. Edom no apareció hasta la entrada de los asirios. Moab y Ammon eran unas entidades pequeñas. Las construcciones monumentales de los Omridas en Samaria, Jezreel y Hazor proporcionan datos sobre la naturaleza de su estado. La arquitectura omrida se caracterizó por la creación de plataformas para los palacios y de puertas bien trabajadas. La mejor demostración de esta técnica se encuentra en Samaría. Los bloques de tamaño enorme y la construcción de Kievra sólo admite comparación con el templo de Herodes en Jerusalem, casi 1000 años después. Jezreel ofrece 
unas características parecidas, que se encuentran también en Hazor. El plano de Meggido es diferente, pero no menos elaborado. Los omridas construyeron dos magníficos palacios de sillares, uno de ellos parecido al palacio de Samaría.

Algunas innovaciones constructivas introducidas por los omridas son conocidas en Palestina en centurias anteriores. Más significativa es la concepción de una fortaleza de mando en manos de una limitada clase de jefes, que controlaba amplios territorios, es una reminiscencia de las fortalezas para la élite de mitad de la Edad del Bronce, en los lugares montañosos como Siquem y Siloh. Para conocer el fenómeno es necesario recordar que el reino del norte fue un estado muy variado, que comprendía una población muy heterogénea. Las montañas y Samaría estaban habitadas por israelitas descendientes de las poblaciones de las montañas del segundo milenio pastoriles y al mismo tiempo sedentarias. Las tierras bajas del sur. Tenían muchos elementos locales, es decir, cananeos.

La arquitectura de estas pequeñas aldeas no cambió mucho y no absorbió las características arquitectónicas israelitas de las montañas. Los mayores centros administrativos israelitas en los valles seguían modelos de las ciudades-estado del Bronce Final.

Desde el punto de vista conceptual y funcional, el trazado del Meggido del siglo IX a.C., no es diferente de su trazado en la Edad del Bronce Final. Grandes zonas de la colina fueron dedicadas a edificios públicos y espacios abiertos. Ciertas áreas eran barrios domésticos. La población estaba compuesta principalmente por una elite de gobernantes, que controlaba el hinterland rural. En el noreste Israel limitaba con territorios de Aram-Damasco. La población era parcialmente aramea, como lo prueba el número importante de inscripciones redactadas en arameo, halladas en muchos lugares del Hierro II. Las montañas de Galilea y la llanura de la costa norte estaban habitadas por grupos vinculados con las ciudades de la costa fenicia. Piensa Finkelstein que la divinidad étnica y cultural del reino del norte parece proporcionar la base para la arquitectura monumental de los omridas. Su propaganda se dirigía a los habitantes de su propio pueblo y a los habitantes de los nuevos territorios. Los omridas necesitaban pacificar su territorio y asegurar su lealtad. Ello era fundamental desde que un fuerte estado emergió, en este tiempo, en las proximidades: Damasco. La construcción de recintos fortificados y de algunos barrios con palacios en el valle de Jezreel y en los límites de Damasco, podían responder a estos objetivos. Fueron construidos como centros administrativos para controlar a poblaciones no israelitas del estado recién establecido. Servían de propaganda y legitimación de una dinastía que mandaba en las montañas; se ha sugerido que Jezreel, en medio de un valle cananeo, servía para intimidar a las poblaciones locales. La actividad constructiva fue completada por una política moderada con la población rural de la Edad del Hierro.

La notable estabilidad de los asentamientos en el valle de Jezreel durante la Edad del Hierro indica claramente que los reyes israelitas no inquietaron el sistema rural cananeo en las tierras bajas del norte. 
El estado Omrida demostró también un cambio y una continuidad. Hubo cambio en el sentido de que los omridas crearon un estado territorial que cubría una gran área de las montañas y las tierras bajas. Se mantuvo la continuidad del viejo sueño de los jefes del país montañoso. La Samaría del siglo Ix a.C. no era muy diferente arquitectónicamente de Siquem.

Piensa Finkelstein que la real solución en la dinámica política vino sólo en el siglo vIII a.C., con la integración del reino del norte dentro de la hegemonía económica asiria y la aparición de un verdadero estado nacional en Judá. El estado nacional produjo una saga histórica muy poderosa.

A. Mazar ${ }^{11}$ del instituto de arqueología de la Universidad Hebrea de Jerusalem ha realizado una serie de observaciones sobre las tradiciones bíblicas y arqueológicas. Evidencias referidas al Israel primitivo. Comenta el autor mencionado las dos posturas ante la Biblia: un extremado fundamentalismo y un extremo revisionismo.

Los seguidores de la corriente revisionista rechazan los datos fiables históricos para los textos bíblicos en la Edad del Hierro y niegan su validez para una reconstrucción histórica de la mayoría de los textos referente a los tiempos prexílicos. Revisionistas más moderados argumentan que, mientras los textos bíblicos fueron compuestos durante el siglo vII a.C., tienen mínimo valor para reconstruir los periodos primitivos de la historia de Israel, principalmente los referentes a la división de la monarquía. Tales puntos de vista han sido expresados por historiadores y arqueólogos israelitas, entre otros Finkelstein, Herzog y Zakovitch. Otros investigadores importantes objetan que, aunque los textos se hayan escrito en el siglo VII a.C., sin embargo han incorporado materiales primitivos anteriores a los de su redacción, y contienen núcleos de datos históricos válidos. Esta afirmación deja una ventana abierta muy ancha, a diferentes interpretaciones. Mazar parte de la posición de un arqueólogo, que es lo que es.

\section{PERIODO DE ASENTAMIENTO}

La discusión comienza con el periodo del asentamiento, que es el primer periodo para el que los datos pueden ser cotejados con documentos escritos extrabíblicos y con la evidencia arqueológica.

En opinión de Mazar, tal comparación muestra que las narraciones bíblicas relativas al periodo de los jueces y a la primitiva monarquía proporcionan un válido armazón para la historia de Israel. La gran influencia que tuvieron la lengua cananea, la literatura y la mitología, en la literatura bíblica, indica un continuo desarrollo desde el segundo al primer milenio antes de nuestra era en el antiguo Israel, y la incorporación de elementos cananeos en la cultura israelita. Los portadores de

11 MAZAR, A. 2003: «Remarks on Biblical Traditions and Archaeological Evidence concerning Early Israel», en DeVER W. G., GITIN S. (eds) 2003, op. Cit., 85-98. 
estas tradiciones literarias cananeas, podían ser los habitantes cananeos de las llanuras de la costa y los del norte del territorio de Israel, como sugiere la investigación arqueológica. Israel podía haber asimilado a estos cananeos en el siglo x a.C., según indicación de la evidencia arqueológica y de los textos bíblicos como $1 \mathrm{Re}$ 9.20-21. Las excavaciones en varias localidades de los valles del norte prueban la continuidad de las tradiciones cananeas y, posiblemente, de la población en el siglo $x$ a.C. Esta continuidad ha quedado bien demostrada en Tell Rehor en el Valle de Beth-Shean. Hay varios puntos de interés que A. Mazar brevemente enumera. Estos puntos prueban que alguno de los textos bíblicos concuerdan con la primitiva evidencia textual externa y arqueológica y que, difícilmente pueden inventarse en el siglo vII a.C., o después.

Estos puntos, según el arqueólogo israelita son los siguientes:

1. Las narraciones bíblicas de la conquista y, concretamente la narración de Josue $^{12}$ y la lista de las ciudades citadas ${ }^{13}$, demuestran la existencia de ciudades-estado en el Canaán preisraelita. Tal conocimiento de la estructura geopolítica de Canaán al final de la Edad del Bronce judía, no pudo haberse inventado en el siglo vII a.C. Debió existir una tradición continua, que conservó esta memoria del final de la Edad del Bronce a la Edad del Hierro. Al igual, las divisiones territoriales del final de la Edad del Bronce, fueron conservadas por extenso, según refleja la descripción de los límites tribales y los distritos de Salomón.

2. La definición de Hazor en Josué ${ }^{14}$ como antigua cabeza de todos estos reinos, refleja el status de Hazor en el segundo milenio a.C. y podía no haber

12 Jos. 1-11.

13 Jos. 12: ${ }^{1}$ Estos son los reyes del país que los israelitas derrotaron y despojaron de su territorio en la parte oriental del Jordán, desde el torrente Arnón hasta el monte Hermón, con toda la Arabá oriental: ¿Sijón, rey de los amorreos que residía en Jesbón y dominaba desde Aroer -a orillas del torrente Arnónhasta el torrente laboc -que sirve de frontera con los amonitas-incluyendo la cuenca del torrente Arnón, la mitad de Galaad, ${ }^{3} y$ el lado oriental de la Arabá, hasta el mar de Genesaret por un lado, y hasta el mar de la Arabá o mar de la Sal por el otro, llegando por el este hasta Bet Ha lesimot, y por el sur hasta más abajo de las laderas del Pisgá. ${ }^{4} \mathrm{Y} O g$, rey de Basán - uno de los últimos sobrevivientes de los Gigantes- que residía en Astarot y en Edrei ${ }^{5}$ y dominaba en el monte Hermón, en Salcá, en todo el Basán hasta las fronteras de los guesuritas y de los maacatitas, y en la mitad de Galaad hasta las fronteras de Sijón, rey de Jesbón. ${ }^{6}$ Moisés, el servidor del Señor, y los israelitas habían derrotado a estos reyes, y Moisés había dado el territorio en propiedad a los rubenitas, a los gaditas y a la mitad de la tribu de Manasés. ${ }^{7}$ Estos son los reyes que Josué y los israelitas derrotaron en el lado occidental del Jordán —desde Baal Gad, en el valle del Líbano, hasta la montaña Desnuda, que sube hacia Seir-cuyos territorios Josué entregó en posesión a cada una de las tribus de Israel, ${ }^{8}$ en la Montaña, en la Sefelá, en la Arabá, en las pendientes, en el desierto y en el Négueb, donde habitaban hititas, amorreos, cananeos, perizitas, jivitas y jebuseos: ${ }^{9}$ el rey de Jericó y el rey de Ai, junto a Betel; ${ }^{10} \mathrm{el}$ rey de Jerusalén y el de Hebrón; ${ }^{11}$ el rey de larmut y el rey de Laquís; ${ }^{12}$ el rey de Eglón y el rey de Guézer; ${ }^{13}$ el rey de Debir y el rey de Guéder; ${ }^{14}$ el rey de Jormá y el rey de Arad; ${ }^{15}$ el rey de Libná y el rey de Adulám; ${ }^{16}$ el rey de Maquedá y el rey de Betel; ${ }^{17}$ el rey de Tapúaj y el rey de Jéfer; ${ }^{18}$ el rey de Afec y el rey de Sarón; ${ }^{19}$ el rey de Madón y el rey de Jasor; ${ }^{20}$ el rey de Sirmón Meroón y el rey de Acsaf; ${ }^{21}$ el rey de Taanac y el rey de Meguido; ${ }^{22}$ el rey de Quedes y el rey de locneam, en el Carmelo; ${ }^{23}$ el rey de Dor, en la región de Dor; ${ }^{24}$ el rey de los Goím, en Galilea, y el rey de Tirsá. En total, fueron treinta y un reyes.

14 Jos. 11.20 . 
sido inventada en el siglo VII a.C., o después. El incendio de Hazor, mencionado en Josue ${ }^{15}$, está apoyado por la evidencia arqueológica de la gran conflagración que destruyó el palacio y del templo de la ciudad. Se ha supuesto que los asaltantes eran israelitas o protoisraelitas. A. Mazar califica la descripción de Josue ${ }^{16}$ como la reflexión de un recuerdo, vivo durante mucho tiempo entre los habitantes locales, de un suceso traumático que acabó con Hazor. Tal acontecimiento podía haber sido retenido entre la población cananéa, que permaneció en el país durante los siglos XII-XI a.C. AI fin fueron asociados a la comunidad israelita de tiempos de la monarquía, con el resultado de que el suceso fue atribuido a Josué en la historiografía posterior.

3. La base económica y ambiental de la aparición de asentamientos, junto con su cultura material, refleja el asentamiento muy extendido de un pueblo con un específico estilo de vida socioeconómico que, en opinión de A. Mazar, coincide con la sociedad premonárquica israelita, tal como la describen las narraciones bíblicas. La continuidad entre muchas de estas localidades y las posteriores aldeas y ciudades israelitas de la monarquía permiten calificar estos asentamientos como israelitas. Mazar considera superfluo el término protoisraelita inventado por Dever en 1992 y aceptado por otros investigadores.

4. Las tradiciones bíblicas relativas al papel de los madianitas en el origen de la religión israelita y el texto que menciona a Yahweh viniendo a Se'ir ${ }^{17}$, que puede relacionarse con Yahweh en el país Sham y la relación entre Sham y el país de Se'ir, probablemente el sur de Tranjordania, mencionado en documentos egipcios del siglo xv a.C. Se han asociado a los madianitas los hallazgos arqueológicos datados en el siglo XIII y XII a.C., de Hazor y de Araba. Esta equiparación es una mera hipótesis.

5. Las citas de Edóm, Moab e Israel en los textos egipcios, fechados en el siglo XIII a.C., tienen una gran significación, aunque estos términos no se refieran a pueblos asentados $\mathrm{o}$ a estados establecidos. La referencia a Israel en la estela de Meneptah ha sido valorada de diferentes modos. Recientemente, 1998, se ha propuesto que esta mención se refiere a un importante grupo de población de Canaán. Se está tentado de identificar el Israel de la estela de Meneptah con el proceso de asentamiento en gran escala en las montañas de Cisjordania, como en el norte de Transjordania, que comenzó al final del siglo XIII a.C.

6. Varias localidades en estas regiones proporcionan datos más concretos. Un buen ejemplo es 'Aï, partiendo de la suposición de que 'Aï es et-Tell. La

\footnotetext{
15 Jos. 11.11 .

16 Jos. 11.

17 De. 33.2; Ju. 5.4.
} 
conquista de Josue ${ }^{18}$ puede explicarse por la evidencia arqueológica del lugar donde se fundó un asentamiento de la Edad del Hierro I, encima de las ruinas de una ciudad fortificada de comienzos de la Edad del Bronce III. Posiblemente la historia de la conquista de 'Aï fue una creación de los colonos de la Aldea de la Edad del Hierro I, como una explicación etiológica de las minas del lugar. La explicación etiológica debía tener ya varios siglos cuando fue integrada en los textos bíblicos.

7. Los resultados de las excavaciones de Shiloh apoyan la tradición bíblica referentes a su historia.

8. El caso del monte Ebal es más complicado. La identificación de la principal estructura del lugar, como el altar construido por Josué ${ }^{19}$, remonta a la identificación de La maseba del templo cananeo de Siquem, como la gran piedra de Sechem mencionada en Josuéro. Estas dos propuestas son discutibles. Algunos de los que rechazan la identificación de la principal estructura como un altar, admiten la función del Monte Ebal como lugar de culto. Aún no aceptando esta identificación, la evidencia del lugar puede indicar que era un lugar de culto en una primitiva fase de asentamiento en la montaña. Recuerdos del periodo del asentamiento referentes al lugar podían haber constituido la base para las tradiciones referentes a la ceremonia del pacto en el Monte Ebal. Esta tradición podía haberse introducido en la historiografía israelita en fecha muy posterior.

9. La investigación sobre la cultura filistea ha trazado una postura que parece adecuarse a la concepción bíblica sobre el origen de los filisteos, sus asentamientos, la identificación y la naturaleza de las principales ciudades filisteas de la Pentápolis. Esta descripción no se pudo inventar en el siglo VII a.C.

10. La reciente investigación en Transjordania ha probado la existencia de asentamientos fortificados durante los siglos XII y XI a.C., desde la región de Amán al Moab Central. Las excavaciones más importantes son las de Tell el-'Umayri al sureste de Amán; las de Lahun, Khirbet al-Mudayna al'Aliya y Khirbet al-Mudayna al-Mu'arraya, en las orillas del río Arnon. Estos nuevos datos dan valor a la tradición bíblica referente a Transjordania en el periodo de la Edad del Hierro. Los hallazgos en los lugares asentados a lo largo del río Arnon pueden referirse a tradiciones bíblicas referentes a Moab durante la Edad del Hierro I.

11. La lista de las ciudades que no fueron conquistadas ${ }^{21}$ concuerda con las ciudades que han sido excavadas: Beth-Shean, Gezer, Megiddo, posible-

18 Jos. 8.

19 Jos. 8.30-35.

20 Jos. 24.27.

21 Ju. I, 27-36: ${ }^{27}$ Tampoco Manasés arrojó a los de Bet-seán, ni a los de sus aldeas, ni a los de Taanac y sus aldeas, ni a los de Dor y sus aldeas, ni a los habitantes de Ibleam y sus aldeas, ni a los que 
mente Acco y Tell Keisan. En estas ciudades la cultura cananea continuó próspera hasta el final del siglo XI a.C., salvo en Taanach, donde la cultura material de comienzos del siglo XII a.C., recuerda a la de los asentamientos israelitas montañosos del centro.

La mayoría de las historias de la conquista, excepto el caso de Hazor, no tienen confirmación arqueológica. Los hallazgos de Taanach sugieren que no fue conquistada. La cultura material de la Edad del Hierro I, de Beth-shemesh, difícilmente puede definirse como israelita, en contraste con la tradición bíblica. Edóm no existía como estado hasta el siglo VIII a.C.

Aparentemente los textos bíblicos referentes a Israel, anteriores a la monarquía, contienen núcleos de realidades históricas y fueron introducidos en la narrativa literaria mucho después. Estos puntos pueden ser confirmados por la arqueología y por los textos extrabíblicos. Confirman la hipótesis de que estos núcleos resultan de memorias históricas que han pervivido durante mucho tiempo, la transmisión de las tradiciones y, quizá, la primitiva historiografía escrita. Mazar se pregunta si la historia detallada del primitivo Israel puede ser escrita basada en tradiciones bíblicas.

Es aceptable la presencia de una entidad israelita en el país a finales del siglo XIII a.C. El status socioeconómico de los israelitas se adapta a la narración bíblica. No se puede resolver todas las cuestiones de los orígenes de Israel y de su protohistoria.

\section{LA MONARQUÍA UNIDA}

Algunos investigadores han negado o minimizado la existencia de un verdadero estado de Israel durante el siglo X a.C. Los textos bíblicos relativos a David y a Salomón serían creaciones literarias del tipo de sagas nacionales. Se trataría de narraciones noveladas, historias motivadas por la ideología, que pretenden glorificar una supuesta edad de oro en Israel. Todavía hay un largo camino que recorrer para negar totalmente la historicidad de la monarquía unida.

\footnotetext{
habitan en Megiddo y en sus aldeas; y el cananeo persistía en habitar en aquella tierra. ${ }^{28}$ Pero cuando Israel se sintió fuerte hizo al cananeo tributario, mas no lo arrojó. ${ }^{29}$ Tampoco Efraín arrojó al cananeo que habitaba en Gezer, sino que habitó el cananeo en medio de ellos en Gezer. ${ }^{30}$ Tampoco Zabulón arrojó a los que habitaban en Quitrón, ni a los que habitaban en Naalal, sino que el cananeo habitó en medio de él, y le fue tributario. ${ }^{31}$ Tampoco Aser arrojó a los que habitaban en Aco, ni a los que habitaban en Sidón, en Ahlab, en Aczib, en Helba, en Afec y en Rehob. ${ }^{32} Y$ moró Aser entre los cananeos que habitaban en la tierra; pues no los arrojó. ${ }^{33}$ Tampoco Neftalí arrojó a los que habitaban en Bet-semes, ni a los que habitaban en Bet-anat, sino que moró entre los cananeos que habitaban en la tierra; mas le fueron tributarios los moradores de Bet-semes y los moradores de Bet-anat. ${ }^{34} \mathrm{Los}$ amorreos acosaron a los hijos de Dan hasta el monte, y no los dejaron descender a los llanos. ${ }^{35} \mathrm{Y}$ el amorreo persistió en habitar en el monte de Heres, en Ajalón y en Saalbim; pero cuando la casa de José cobró fuerzas, lo hizo tributario. ${ }^{36}$ Y el límite del amorreo fue desde la subida de Acrabim, desde Sela hacia arriba.
} 
El uso de la arqueología depende de los datos correctos de los estratos arqueológicos, es tema de debate frecuente.

Según la cronología baja propuesta por Finkelstein, la fecha de los estratos y de los edificios tradicionalmente fechados en época de Salomón, como Megiddo IVB-VA, Hazor X y la puerta de seis cámaras de Gezer VIII podían llevarse al siglo IX a.C., al periodo de la dinastía omrida. Para Mazar, los datos estratigráficos de Hazor, de Tel Rehov y de otros lugares son extraordinariamente interesantes y le inclinan a proponer que las cerámicas de estos estratos comienzan a aparecer durante el siglo $x$ a.C., y continúan con ligeros cambios hasta el siglo IX a.C. La monarquía unida puede describirse como un estado en una primera etapa de evolución, lejos de ser la rica y expansiva etapa de la narración bíblica. En su argumentación realiza una serie de consideraciones:

1. La ciudadela de Tell el Fûl reconstruida y estudiada por sus excavadores es la única en el tiempo y en la región; quizá podría identificarse con la fortaleza de Saul. Si ello es cierto, podía significar el comienzo de la administración centralizada y de la arquitectura pública a lo largo de los asentamientos montañosos, pero la fecha de Tell el-Fûl es dudosa.

2. Una prueba de la improbabilidad de una administración central fechada en los siglos $\mathrm{X}$-IX a.C., es la ausencia de literatura en el siglo $x$ a.C. Hay menos inscripciones datadas en el siglo $I X$ a.C., que en el siglo $x$ a.C., si se exceptúan las dos estelas reales, moabita y aramea, levantadas por Mecha en Didón y por Hazael en Tel Dan. Se han atribuido sólo al siglo x a.C., la inscripción de Gezer y tres pequeñas inscripciones procedentes de Tel Batash, Tel Amal y Rosh Zayit, a las que pueden añadirse unas cortas inscripciones de Beth-Shemesh y Tel Rehov. Se han fechado en el siglo Ix a.C., sólo cuatro ostraca de Arad, de valor estratigráfico y cronológico discutible; la breve inscripción de Tell el-Hammash y la inscripción de Kuntiller 'Ajrûd, fechada aproximadamente en el 800 a.C. Si se está de acuerdo en la existencia de un estado desarrollado durante el siglo Ix a.C., al menos en el norte, deberíamos preguntarnos dónde están las inscripciones de este estado.

A. Mazar piensa que la ausencia de un número importante de inscripciones fechadas en el s. $x$ a.C. no excluye la existencia de un estado durante este siglo. Las pocas inscripciones del siglo $x$ a.C., demuestran que en Israel se conocía la escritura durante los siglos X-IX a.C., se puede suponer que la mayoría de los documentos escritos de este periodo lo fueron en material perecedero, como papiro y pergamino.

3. La baja densidad de asentamiento y la ausencia de urbanización en el siglo $x$ a.C., se han utilizado para minimizar e incluso excluir la existencia de una monarquía unida. Es difícil extraer conclusiones de los lugares que fueron habitados continuamente a lo largo de la Edad del Hierro. La mayoría de la cerámica recogida podría proceder de la última fase de ocupación. Sólo una 
excavación estratigráfica podría dar a conocer la historia de toda la ocupación. Los cálculos sobre el número de asentamientos de los siglos x y IX a.C., están sujetos a errores importantes, que distorsionan los resultados. Se ha calculado que durante el siglo x a.C., había $200 \mathrm{Ha}$ construidas en Judá, con una población de unos 50.000 habitantes. En el siglo vIII a.C., estas cifras se triplicaron en vísperas de la invasión de Senaquerib (704-681 a.C.). Si estas cifras son aceptables para los siglos X-IX a.C., Judá tenía un número suficiente de asentamientos y una población numerosa para ser considerada un estado pequeño.

Los lugares excavados en Israel y en Juda, como Beersheba, Tell Beit, Mirsim, Beth-Shean, Beth-Shemesh, Tell el-Far'ah, Hazor, Tel Kinneret, Megiddo, Tell en-Nasbeh, Tel Rehov y otras, prueban la evidencia de un comienzo de urbanización en Israel durante el siglo $x$ a.C. Fue el primer eslabón de un desarrollo que continuó en los siglos sucesivos. La urbanización fue acompañada de un cambio en la cultura material que se caracterizó por la terminación de la cerámica de tradición cananea, de la metalurgia, etc., y la aparición de nuevas tradiciones que se desarrollaron durante la Edad del Hierro II.

4. La ausencia de los hallazgos fechados en el siglo $x$ a.C. en Jerusalem se ha presentado por algunos investigadores como argumento para disminuir la historicidad de los relatos bíblicos referentes a la monarquía unida de David y de Salomón. La arqueología de Jerusalem plantea numerosos problemas. La ausencia de hallazgos por un periodo de más de 800 años que va desde la Edad del Bronce Medio hasta el siglo vIII a.C., en Jerusalem plantea problemas y se llega a interpretaciones diferentes. La explanación, la fuerte erosión y la posterior construcción podían haber destruido los restos más antiguos.

Aproximadamente, la mitad de la supuesta ciudad del siglo $x$ a.C. se encuentra debajo del monte del templo actual, que es desconocido arqueológicamente. La estructura de bloques de piedra en el área $\mathrm{G}$ en la ciudad de David es el único vestigio arqueológico de la Edad del Hierro. Se trata de una muralla excepcionalmente larga que, probablemente, pertenece a una gran construcción. Este edificio fue levantado, probablemente, entre los siglos XIII y $x$ a.C. Seguramente se trata de la ciudadela de Zión que David conquistó e incorporó a su propia ciudadela ${ }^{22}$. Otros lugares de Shilo ha proporcionado cerámica de los siglos X-IX a.C., en número pequeño que excluye que se califique a Jerusalem como una gran ciudad. Sin embargo, no se puede afirmar que la ciudad no existía, o que no tenía estructuras monumentales.

22 2Sam. 5.7. 
5. La opinión del arqueólogo Yadin sobre los hallazgos de Gezer, de Hazor y de Megiddo, aludidos en $1 \operatorname{Re} 9.15^{23}$, ha sido aceptada por unos y negada por otros investigadores. Recientemente, basado en las excavaciones de Hazor, la fecha de la Edad del Hierro II es aceptada. El estrato IVB-VA de Megiddo, con monumentales palacios, en la actualidad se tiende a aceptar que pertenece a los tiempos de Salomón. No es improbable que la puerta con seis cámaras pertenezca a este estrato.

6. No puede ser invención del siglo VII a.C., o de fecha posterior, la referencia a la campaña de Shishak del año 925 a.C., mencionada en 1Re. 14.25-28: ${ }^{25}$ Al quinto año del rey Roboam subió Shishak rey de Egipto contra Jerusalén, ${ }^{26}$ y tomó los tesoros de la casa de Jehová, y los tesoros de la casa real, y lo saqueó todo; también se llevó todos los escudos de oro que Salomón había hecho. ${ }^{27} \mathrm{Y}$ en lugar de ellos hizo el rey Roboam escudos de bronce, y los dio a los capitanes de los de la guardia, quienes custodiaban la puerta de la casa real. ${ }^{28}$ Cuando el rey entraba en la casa de Jehová, los de la guardia los llevaban; y los ponían en la cámara de los de la guardia». Las varias campañas egipcias a Canaán durante finales de la Edad del Bronce, todas siguieron las rutas de la llanura de la costa y de los valles del norte. El ejército de Shishak atravesó la región montañosa situada al norte de Jerusalem. Debió existir en el centro un poder político importante para obligar a los egipcios a no seguir la ruta corriente. Sólo podía ser el estado de Salomón. La invasión de Shishak podía obedecer a la situación creada a la muerte de Salomón.

7. Los 70 lugares, que menciona la lista de Shishak en Negev deben asociarse a la ola de corta duración de asentamientos en la zona montañosa del Negev y en la región de Beersheba/Arad, incluyendo 50 construcciones bien planeadas y fortificadas, cuya cultura material indica una simbiosis entre los habitantes locales y de Judá. A. Mazar data estos lugares en el siglo x a.C., y los vincula con la expansión de la monarquía israelita en este periodo. La campaña de Shishak pretendía, seguramente, acabar con la penetración israelita en la región.

8. Los hallazgos de Horbat Rosh Zayit y su posible identificación y su identificación con la bíblica Cabul concuerdan con la historia bíblica de la tierra de Cabul contra el corazón de las relaciones fenicio-israelitas en época de Salomón y posterior.

9. La decadencia de la ciudad filistea de Ekron durante el siglo $x$ a.C., puede ser el resultado de la expansión israelita hacia el oeste en el valle de Sorek, durante la monarquía unida, como queda claro en Tel Batash y en BethShemesh. El incremento de la localidad de Ashdod durante este periodo

${ }^{23}$ Esta es la razón de la leva que el rey Salomón impuso para edificar la casa de Jehová, y su propia casa, y Milo, y el muro de Jerusalén, y Hazor, Meguido y Gezer. 
puede ser el resultado de un movimiento de población de Ekron a Ashdod, como resultado de la presión israelita en Shephelah al oeste.

10. La incorporación de ciudades y de aldeas cananeas a la esfera de influencia israelita durante el siglo $\times$ a.C., puede detectarse en Jokneam, Megiddo y Tel Rehov. Mantuvieron su carácter cananeo hasta finales del siglo $\mathrm{xI}$ o hasta las comienzos del siglo $\mathrm{x}$ a.C. Su cultura material es muy parecida a la de otros lugares israelitas de este periodo.

11. La descripción del templo de Salomón es un recuerdo de templos del levante del segundo milenio a.C., como, también, de templos de los siglos IX-VIII a.C., de Tell Tainat y de 'Aim Dara, en el norte de Siria, pero no de posteriores. Esta descripción no se pudo inventar en el siglo vII a.C., o después.

12. La referencia a la Casa de David en la estela aramea de Tel Dan, como el nombre del reino de Judá en el siglo Ix a.C., se data un siglo y medio después. David era reconocido en la región, tanto como fundador de la ninastía, como soberano de Judá. El papel de David en la ideología y en la historiografía puede ser negado.

A. Mazar deduce de su exposición que la existencia de la monarquía unida no puede ser negada. Su evolución no es lineal. David y Salomón desempeñaron un papel importante en la historia. Líderes carismáticos podían crear pequeños estados con expansión territorial importante y poder militar y político. Si se admite la cronología tradicional, la arqueología puede revelar mucho sobre la monarquía unida, que parece haber contribuido al comienzo de una nueva era, que alcanzó su punto culminante en los siglos IX-VIII a.C.

Se puede aceptar que gran parte de la narración bíblica sobre David y Salomón, es fricción, incluso que las descripciones de las campañas y de la expansión territorial, parecen estar exageradas por los escritores posteriores, como la conquista de Transjordania y de Siria. La no construcción de la monarquía unida que hoy está de moda en algunos círculos se basa, según A. Mazar, en una inaceptable interpretación de los datos arqueológicos. Este autor cree que el texto bíblico conservaría hechos sacados de antiguos documentos escritos y tradiciones locales basadas en la memoria, que han perdurado mucho tiempo. Muchas de estas tradiciones contienen un núcleo histórico y algunas pueden ser examinadas con la arqueología. Conjugando la literatura, los estratos ideológicos y teológicos de los textos y con el uso inteligente y crítico de los datos arqueológicos, los textos pueden ser evaluados como un material puro para la extracción de los datos históricos.

S. Parpola ${ }^{24}$, miembro del Instituto de Estudios Asiáticos y Africanos de la Universidad de Helsinki, ha tratado la repercusión de las invasiones asirias en Oc-

24 PARPOLA, S. 2003: «Assyria's Expansission in the $8^{\text {th }}-7^{\text {Th }}$ centuries and its Longe-Term Repercussions in the West», en DeVer W. G., Gitin S. (eds) 2003, op. cit., 103-111. 
cidente. Tan sólo nos referimos a su pensamiento sobre el efecto de estas invasiones en Judá.

Judá permaneció como un reino semidependiente no incorporado dentro de las provincias asirias. Sin embargo la influencia asiria se incrementó, principalmente en el reinado de Manasés (692-638 a.C.) como se desprende de las fuentes bíblicas y de la arqueología. El impacto religioso e ideológico asirio se detecta en los sellos de fundación local y en los objetos de culto. La arqueología prueba que la economía de Judá, al menos indirectamente, obtuvo provecho del nuevo orden internacional creado por los asirios.

Manasés y sus sucesores pagaron tributos, participaron en las campañas y en los proyectos constructivos. S. Parpola señala una diferencia importante entre Lidia y Judá en sus relaciones con Asiria. Mientras Giges, aparentemente buscó la protección de Asiria voluntariamente, el vasallaje de Judá a Asiria no fue una opción, sino un medio para evitar una total aniquilación. El destino del reino del norte y el sitio de Jerusalem por Senaquerib fueron una lección para Manasés. Algunos autores gan detectado paralelos entre el Deuteronomio y los tratados neoasirios, principalmente el tratado de Esarhaddón (680-669 a.C.). El paralelo sólo se detecta en dos puntos: en las relaciones entre las partes del tratado y en el destino despiadado de los que violan los términos del tratado.

No sólo el rey de Judá, sino toda la clase dirigente era conocedora de los términos del tratado con Asiria. El hecho de que el lenguaje estuviera cercano a fórmulas de leyes en el Deuteronomio 13, tiene implicaciones trascendentales. Parece que el concepto deuteronómico de Dios es fundamental para el judaísmo posterior y se debe a la religión asiria y a la ideología regia. Esta conclusión está apoyada por los desarrollos paralelos en otros lugares dentro del área del imperio neoasirio. Anu, el dios del cielo en Uruk en tiempos post-asirios se transformó en un dios universal a través de su equiparación con Assur, cuyo culto pasó a Uruk en tiempos de Sargón. El dios Sin de Harran, dios lunar, fue promovido a dios universal por el rey babilonio Nabónido (555-539 a.C.), e identificado con Assur ya en el Imperio Asirio. Posiblemente se creó un dios imperial más aceptable para las masas que hablaban arameo. El supremo dios del Imperio Aqueménida, Ahura Mazda, fue identificado con Assur, como lo prueba la adopción por la dinastía aqueménida del disco alado de Assur como emblema de Ahura Mazda.

Es difícil separar estos desarrollos de las transformaciones contemporáneas del concepto de Dios del Deuteronomio, particularmente en Ezra 1.2. El supremo dios del Imperio se identifica con Yahweh, el dios del cielo.

S. Parpola se pregunta qué hubiera sucedido si Asiria no se hubiera extendido hasta las playas del Egeo y del Mar de Galilea. Este proceso no hubiera sucedido sin los cruciales estímulos de Asiria. Las condiciones económicas, intelectuales y psicológicas permitieron la cristalización de la imagen bíblica de dios, que no sucedió antes de la llegada de los asirios. 
M. S. Smith ${ }^{25}$, profesor en el Departamento de Estudios Hebreos y Judíos de la Universidad de Nueva York, analiza a Yahweh, El y a la Familia Astral Divina en la Judá de la Edad del Hierro II. Comienza su trabajo indicando que desde hace tres décadas hay un debate sobre los fundamentos de la religión astral en la Judá de la Edad del Hierro II. Revisa las teorías de Cogan expuestas en un importante libro sobre el imperialismo y religión ${ }^{26}$, donde el autor examina exhaustivamente los textos acadios que sugieren una libertad en materia de cultos locales, contraria a la reputación negativa atribuida por los investigadores a la política del Imperio Neoasirio.

A parte del carro del sol mencionado en 2Re. 23.11, Cogan encuentra poco claro la influencia neoasiria en los cultos astrales de Judá. Tiende a considerar los cultos astrales como un aumento de tradiciones locales, arraigado popularmente. Sorprende que discutiendo la reina del cielo ${ }^{27}$, Cogan utiliza porco las tortas dedicadas a su culto.

En la Biblia se encuentran pocos rasgos que parezcan ser neoasirios: el culto a Tamuz ${ }^{28}$ y las referencias al mazzelôt/mazzarôt ${ }^{29}$.

Se ha mencionado que el comercio y la influencia económica podían haber jugado un papel imortante en el imperio neoasirio con la administración política. La contribución de Cogan parece zanjar el problema de la imposición del culto neoasirio en Judá durante el Hierro II.

Spieckermann sugiere una imposición neoasiria de la política religiosa y de la práctica en el Hierro II en Judá, incluyendo el culto de Ishtar, bajo la capa de la Reina del Cielo. Un culto neoasirio astral hubo bajo la forma del sol, de la luna y del ejército del cielo, añadiendo los caballos y el carro del sol. De influencia neoasiria serían varias prácticas religiosas en Judá, oráculos, observación del cielo y de los presagios, observación del tiempo y del calendario, oración, ritual y profecía femenina. Spieckermann considera instrumentos de la imposición religiosa neoasiria los templos locales, incluyendo el templo de Jerusalem. Esta hipótesis de trabajo encuentra un débil apoyo en las fuentes escritas. Cuando las fuentes bíblicas identifican la influencia mesopotámica, mencionan Sakkuy y Kaiwan ${ }^{30}$ en Amos, y Tammuz en Ezequiel ${ }^{31}$, o los dioses mesopotámicos.

Stäli se detiene en los mosaicos judíos de las sinagogas, como la de Beth Alpha, con elementos astrales. Recoge una amplia variedad de textos y sugiere una

25 SMITH, M. S. 2003: «When the Heaven Darkened. Yahweh, El and the Divine Astral Family in Iron Age II. Judah", en Dever W. G., Gitin S. (eds) 2003, op. Cit., 265-276.

${ }_{26}$ Cogan, M. 1974: Imperialism and religion 'Assyria' Judah and Israel in the Eight and Seventh Centuries BCE, Misoula.

27 Jer. 7 y 44.

28 Ez. 8.

29 2Re. 23.5 y Job. 38.22 .

30 Am. 5.

31 Ez. 8. 
variada capa de elementos solares en la religión tradicional israelita ${ }^{32}$ y en los nombres de lugares y de personas. Este autor no se plantea la influencia neoasiria, pero apoya las posturas de McKay y de Cogan.

Keel y Vehlinger estudian la iconografía de los dioses en el antiguo Israel y demuestran la posible coherencia entre la iconografía y los documentos escritos. El aumento importante de los cultos astrales en Judá, con sus astrales imágenes de símbolos celestes, resulta de la influencia asirio-aramea, como consecuencia de la presencia imperial neoasiria. Aunque existían viejos elementos astrales en la religión israelita. M.S. Smith se pregunta si la astralización fue conforme al viejo culto astral de los semitas occidentales, incluyendo las viejas deidades astrales indígenas. Dioses astrales que eran parte de las tradiciones religiosas semitas occidentales siempre estuvieron presentes. Finalmente Thener analiza la devoción lunar en la religión sirio-palestina, notando la evidencia en Ugarit del dios lunar, así como el aumento del culto lunar en la Judá del Hierro II, bajo influencia asirio-aramea, en particular debido al culto lunar de Harrán.

La última religión de Israel pudo tener un culto de El, que incluía un número mínimo de deidades astrales. La familia astral de El puede subyacer a la divina cuestión propuesta $\mathrm{a} \mathrm{Job}^{33}$. Este texto se ha relacionado con los cuerpos astrales. La asociación astral de Dios aparentemente, yace detrás de la polémica en Isaías ${ }^{34}$ contra el rey de Babilonia que intentó al cielo y elevar su trono por encima de las estrellas de El.

Yahweh es identificado a El y asociado con deidades astrales en la forma del ejército del cielo. Yahweh podía aparecer como el gran monarca sobre todos los cuerpos celestes. Taylor indica algunos pasajes ${ }^{35}$, como prueba de la evidencia de la asociación del dueño del cielo con el culto a Yahweh. El Libro de los Reyes ${ }^{36}$ menciona la construcción de altares para todos los ejércitos del cielo en los dos atrios de la Casa de Yahweh. Otro texto, probablemente relacionado con el sol y la luna, como parte del ejército de Yahweh ${ }^{37}$. En sueño de Josés ${ }^{38}$, con el sol, la luna y las estrellas caen en este contexto. Estos textos son suficientes para propagar las creencias astrales en Israel. Es particularmente importante la mención del Libro de los Reyes ${ }^{39}$ que presupone el concepto astral de ejército del cielo, por ser anterior al influjo del imperialismo neobabilonio.

M.S. Smith recuerda que se ha aducido un número de sellos fechado en el siglo vII a.C., que pintan, probablemente, a Yahweh como el celestial/lunar El.

\footnotetext{
32 A este respecto: Mal. 3.20 y Salm. 84.

33 Job. 38.6-7.

34 Is. 14.13

35 1Re. 22.19; Zac. 1.5.

36 2Re. 21.5.

37 Jos. 10.12 .

38 Ge. 37.9.

39 1Re. 22.19
} 


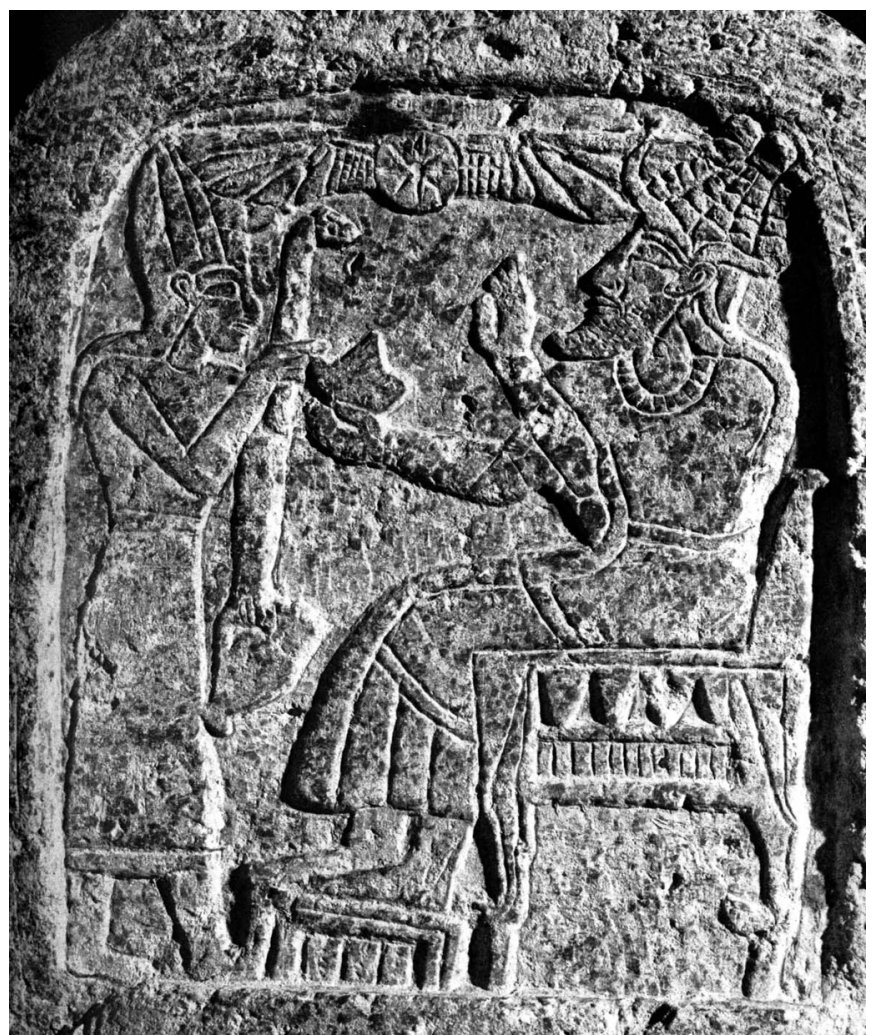

Figura 2: Detalle de una estela de Ugarit representando al rey haciendo una ofrenda al dios supremo El. Museo Arqueologico Nacional de Alepo.

Quiza, en la última fase en la carrera de los dioses astrales en la religión de Israel, los textos bíblicos critican las deidades astrales dentro del culto de Yahweh, bajo el título de sol, luna y estrellas. M.S. Smith cree posible este criticismo representado por las prohibiciones de la amenaza del culto astral neoasirio durante el Hierro II, pero esto no disminuye el carácter indígena de la devoción al sol, a la luna y a las estrellas.

Este investigador ha analizado, también, a El y a Yahweh, y el desplazamiento de la religión astral en Israel. La identificación de Yahweh y de El en el interior de Israel, quizá tiene ramificaciones para la continuación de otras deidades.

Se ha supuesto que Asherat es la compañera de Yahweh como resultado de su identificación con él. Esta identificación ha podido aceptar a la historia de los dioses astrales en el antiguo Israel. Quizá, los dioses astrales asociados en origen con El, llegaron a ser parte de la divina asamblea subordinada a Yahweh, y la imaginería asociada a Yahweh llegó a dominar el discurso religioso israelita y quizá el desplazamiento del lenguaje astral. M.S. Smith se pregunta si El fue el originario 
dios de Israel; como Yahweh vino a ser el dios principal de Israel e identificado con El. Este autor encuentra posibles tres desarrollos hipotéticos:

1. El fue el dios original del primitivo Israel. El nombre de Israel podría apuntar a esta etapa, como indicarían algunas referencias a El como figura separada de Dios que emergería como dios nacional de Israel ${ }^{40}$.

2. El fue la cabeza de un primitivo panteón israelita con Yahweh como dios guerrero. Los textos, que mencionan a ambos, El y Yahweh, pero no como la misma figura ${ }^{41}$, sugieren una primitiva acomodación de los dos en una primitiva forma de politeísmo israelita. Si el salmo 82 refleja un antiguo modelo de una asamblea politeísta israelita, El podía haber sido su cabeza, con Yahweh guerrero como miembro de segundo grado. Este salmo emplea un lenguaje familiar, los otros dioses han dicho ser los hijos del más alto. Yahweh debe haber sido el primero comprendido como padre de estos hijos.

3. El y Yahweh son identificados como un sólo dios. Si El fue el dios original de Israel, su fusión con Yahweh tuvo lugar de diferentes formas, en diferentes partes del antiguo Israel. Muchos investigadores colocan en Jueces 5 en el periodo premonárquico y, quizá, el culto de Yahweh, se extendió más lejos en las montañas de Israel en este periodo, infiltrándose en los lugares de culto de El y acomodándose a la teología de El. Las referencias a El de el Libro de los Números ${ }^{42}$ y, probablemente en Job ${ }^{43}$ parecen ser indicaciones más lejanas de una supervivencia separada del culto de El en Transjordania. Quizá como parte de esta identificación, Yahweh, dios de la tormenta, asimiló la mitología astral de El. Esta mitología astral ocupó un lugar detrás de la imaginería más dominante de la tormenta asociada con el dios nacional israelita.

Si el trazado general de este desarrollo tiene cierta posibilidad de validez, que puede sospechar que la religión astral de Judá del Hierro II no implicaba una imposición imperial. Implicaba una práctica de larga duración con cierta influencia neoasiria más lejana.

El prestigio político y económico del Imperio Neoasirio, podía sugerir algunas pistas de influencia. M.S. Smith se inclina por la teoría de Cogan, contra la opinión de Taylor, que ve influencia neoasiria detrás de los caballos del sol en el Libro de los Reyes ${ }^{44}$. Planteada la discusión en estos términos, se podría sugerir que algunos monarcas y el pueblo de Judá en el Hierro II casaron la tradicional política con analogías neoasirias recientes.

40 Ge. 49; Salm. 82.

41 Ge. 49; Num. 23-24; Salm. 82.

42 Num. 23-24.

43 Job. $5.17 ; 6.4$.

44 2Re. 23.11. 
El influjo asirio difícilmente pudo entrar en conflicto con la vieja devoción religiosa. Esta situación no fue única en Judá durante el Hierro II. Una situación parecida, el culto de divinidades indígenas, sobrevivió en el Ekron filisteo, a pesar del estatus de vasallo. En Judá, su vieja práctica cananea podía necesitar una revitalización. La evidencia existente permite la conclusión de que tales prácticas eran totalmente funcionales y no en oposición a la influencia neoasiria.

M.S. Smith concluye su importante estudio con la afirmación que los investigadores han comparado El o Baal con Yahweh. Athtar y Yahweh son dioses de zonas relativamente áridas. Athtar y Yahweh, podían haber compartido características más próximas que Baal y Yahweh, como se supone frecuentemente. Yahweh fue en origen un dios del sur de Edóm, posiblemente del noroeste de Arabia Saudita, conocido por los nombres bíblicos de Edóm, Midiam. Teman y Sinai. Este área general del viejo culto yahwishta está atestiguada no sólo por la Biblia ${ }^{45}$ sino también por las inscripciones. Las inscripciones de Kinkillet 'Ajrûd mencionan a Yahweh de Temar. El movimiento del culto de Yahweh de la zona sur de Edóm/Sinai/Temar atestiguado en fuentes políticas podía concordar con una segunda asimilación de Yahweh con Baal, de aquí un impresionante dios de la tormenta, de la costa, exactamente como Yahweh fue secundario en los lugares de culto de El en las tierras altas, tales como Sichem, Shiloh y Bethel. El Salmo 29 se podía leer como un himno dirigido a Baal, reescrito a Yahweh.

M.S. Smith propone considerar las siguientes posibilidades teóricas:

1. En Ugarit, la familia astral de El fue desplazada por el culto a Baal.

2. En Israel sucedió algo parecido Yahweh fue en origen no un dios de la tormenta, sino una deidad cuyo carácter de desierto y astral (?) pudo haber sido desplazado por una religión de la costa y de las montañas del dios de la tormenta, presentado en origen en la tradición bíblica como dios nacional de Israel. Si el conflicto entre Baal y Athar de los textos de Ugarit fue paralelamente más tarde al conflicto entre Baal y Yahweh, la solución de este conflicto religioso en la forma de atribuir la monarquía de la costa a Yahweh, debió haber oscurecido el perfil que Yahweh pudo compartir con una figura, como Athar, incluyendo una asociación astral.

M.S. Smith concluye que Judá durante el Hierro II, tuvo un desarrollo general y un desplazamiento de las viejas características religiosas tradicionales.

Esta dislocación, en la forma de la crítica bíblica a los dioses astrales, pudo oscurecer, no sólo la tradición astral en general, sino toda posible característica astral de Yahweh. El perfil original del dios bíblico, al menos en parte, puede perderse totalmente. Parece evidente que muchas fuentes bíblicas reflejan secundariamente desarrollados el perfil específico de Yahweh.

45 Dt. 32.2; Ju.5.4-5; Salm. 68.9.18; Ha. 3.3. 
S. Gitin ${ }^{46}$ del W.F. Albright Institute of Archaeological Research de Jerusalem ha estudiado el culto israelita y filisteo y el documento arqueológico en la Edad del Hierro II.

Las prácticas religiosas del antiguo Israel y de sus vecinos se han analizado mucho desde comienzos del siglo pasado.

En algunos casos los datos arqueológicos fueron empleados para probar la autenticidad de las prácticas religiosas bíblicas. Un ejemplo son los altares de cuatro cuernos fechados en el Hierro II y hallados en contextos arqueológicos israelitas, que se acomodan a la descripción de los altares de incienso con cuatro cuernos en la Biblia; esto ha sido aducido por ciertos investigadores para demostrar la validez de las prácticas de quemar incienso, citadas en la Biblia. En la actualidad se matiza mucho. En la discusión del primitivo desarrollo del monoteísmo existe la controversia si una diosa recibió culto al mismo tiempo que Yahweh, quizá como su consorte. Lo que motivó esta discusión fue la inscripción descubierta en la excavación, efectuada en el año 1976, hallada en una tumba de Judá, fechada en el siglo VIII-VII a.C., en Kirbet el Gôm. Varios investigadores traducen la inscripción: "Yahweh y su Aserah». La discusión aumentó cuando en las excavaciones de Meshel en Kintillet 'Ajrûd, en una posada de caravanas del Sinaí, de mediados del siglo vill a.C., aparecieron pinturas e inscripciones sobre dos jarras. En una inscripción se lee: « $A$ Yahweh de Samaría y a su Ahserah». Esta inscripción ha motivado un arduo debate sobre el monoteísmo y el politeísmo en la antigua religión israelita, llegando a interpretaciones diferentes de la palabra Aserah, como diosa, un objeto de culto, que simboliza la deidad o la consorte de Yahweh. Esta discusión afecta, no sólo la comprensión del primitivo monoteísmo en la religión de Israel, sino al estudios de la religión de los filisteos. Las dos inscripciones sobre jarras de Tel Miqne-Ekrom, en las que se lee «dedicada a aserah», halladas en una construcción aneja del templo 654, indican que esta diosa recibió también culto por los filisteos. Se deduce del contexto de las jarras, donde estas inscripciones fueron encontradas, que se refieren a su diosa y no a su símbolo.

Otro problema es si existió o no la monolatría en la religión anterior al destierro de Israel; si se reconoció a otros dioses, pero no necesariamente fueron adorados, como en el politeísmo.

Tigay en 1986 examinó más de 1200 nombres personales israelitas y de Judá y sus teóforos compuestos unos de Yahweh y otros documentados en inscripciones de la edad del Hierro II. Tigay acepta que este tipo de documentos refleja el sistema religioso israelita. Del problema es si los israelitas veneraban a otros dioses además de a Yahweh.

Posteriormente se estudió el aniconismo en la religión de Israel, es decir, la ausencia de una imagen de la divinidad, humana o animal, opuesta a la idolatría, en

46 GITIN, S. 2003: «Israelite and Palestine cult and the Archaeological Record in Iron Age II», en DEVER W. G., GITIN S. (eds) 2003, op. cit., 279-297. 
la que la deidad se veía como un objeto con imagen divina o símbolo. Hay evidencia arqueológica de objetos de culto anicónicos, representados como piedras hincadas, pilares, frecuentemente mencionadas como casas de los dioses. En el Negeo y en el Sinaí hay decenas de estas piedras hincadas en lugares prehistóricos. El aniconismo tiene una historia de miles de años, una larga tradición que llega hasta finales del siglo VIII a.C., antes del rey Ezequías de Judá (727-698 a.C.). La prohibición de las piedras hincadas debió ser, por lo tanto, un fenómeno tardío. Existen evidencias de piedras hincadas en Arad, en Dan y en otros lugares.

S. Gitin presta especial atención al artefacto humeante, que es un criterio esencial para evaluar y dar autenticidad a las prácticas religiosas bíblicas. El estudio del culto filisteo data de los últimos diez o quince años del siglo Xx. La excavación de Tel Miqne-Ekrom ha producido una masa de información básica para un estudio bien documentado de la política del culto filisteo para el periodo del Hierro I-II. S. Gitin examina la ciudad del siglo VII a.C., del último periodo filisteo. Ekrom fue fundada en el siglo XII a.C., por los filisteos de los Pueblos del Mar, como una de las cinco capitales. En el siglo vIII a.C., alcanzó su cenit de crecimiento económico. En este periodo fue un centro de comercio internacional. Desarrolló una gran industria de aceite. Las excavaciones han proporcionado una enorme cantidad de piezas de culto epigráficas y anepígrafas. Los datos son de tres tipos: artefactos humeantes, objetos en contextos y en textos, y material de culto. La mayoría proceden del santuario en el ala oeste del templo 650 y del edificio anejo al templo 654 en la zona noble.

El templo 650 es uno de los más grandes edificios excavados en Israel. La planta es única en todo el Levante, y sigue modelos de la arquitectura neoasiria, con tres componentes: al oeste un gran atrio abierto, de planta cuadrangular con habitaciones alrededor; una gran habitación del trono, también de forma rectangular algo estrecha, o hall de recepción en el centro; en el extremo hay un trono con escalones; al oeste se encuentra un templo. Como en los edificios monumentales neoasirios, la habitación del trono servía como límite entre las alas este y oeste. La parte más noble es el templo 650, de planta rectangular con un monumental umbral con escalones de piedra. El hall del templo fue revestido con dos hileras paralelas de cuatro basas de columnas. Al fondo hay una cella realzada. El plano del templo, de pilares, recuerda un diseño fenicio, como el del templo de Astarté de Kition, en Chipre.

En el templo-santuario del templo 650 se encontró un artefacto humeante y la inscripción de la dedicatoria real de Ekrom. Es el artefacto más importante hallado en las excavaciones y uno de los más importantes hallados en Israel. La inscripción dice: «El templo, que ha construido Ikausu, hijo de Padi, hijo de Ysd, hijo de Ada, hijo de Ya'ir, gobernador de Ekrom, para Ptgyh su dama, puede ella bendecirla, protegerse y prolongar sus días y bendecir su tierra». La inscripción es un testimonio del culto filisteo.

El rey, Ikausu, de nombre no semita, atestigua el carácter filisteo de la inscripción. El rey construyó el templo donde se halló la inscripción. El nombre del rey 
está en relación con el término aqueo, dado que los filisteos venían del Egeo. La ciudad, donde Ikausu gobernaba, está mencionada en la Biblia como Ekrom, conocida como la capital de la pentápolis filistea ${ }^{47}$ y en los anales neoasirios. El nombre de la diosa, no semita, es Ptgyh, a la que lkausu dedica el templo. Ptgyh se asocia en Delfos a la diosa madre micénica. La inscripción es un primer ejemplo de convergencia de un artefacto y de un templo, que indica la fecha de la construcción del templo y de la inscripción en el primer cuarto del siglo VII a.C. Dos de los nombres mencionados en la inscripción aparecen en los anales asirios como reyes de Ekrom, ciudad vasalla de los asirios. Padi pagó un talento a Senaquerib. Ikausu transportó material para levantar el palacio de Esarhaddon. Participó en la primera campaña de Assurbanipal contra Egipto en 667 a.C. La última fase del santuario y la inscripción se datan en el 604 a.C., cuando fue destruido por el rey neobabilonio Nabucodonosor en su campaña a Filistea. Ekrom, a finales del siglo VII a.C., ha dado artefactos de culto, varias inscripciones, una figurilla y altares de incienso de cuatro cuernos, que dicen bien el carácter del culto filisteo antes de la destrucción. Es importante una figura femenina de estilo fenicio, que es la única hallada en un templo y que define el contexto del culto en el Levante. Posiblemente es una imagen de la diosa que presidía el santuario. Imágenes parecidas se han hallado en Motya, en Cartago o en Tharros. En un fragmento de jarra se grabó una inscripción de dos palabras de carácter cúltico. Se halló en una de las habitaciones del templo, junto con tres piezas de marfil de un probable instrumento musical procedente de Egipto. La inscripción dice: «Para Baal y para Padi», esto indicaría que Baal fue uno de los dioses de los filisteos. Otras inscripciones sobre jarros se encuentran en el edificio auxiliar del templo; en una de ellas se lee: «Dedicado a Asherat». Demuestra que la diosa de los semitas occidentales y de los cananeos era venerada en Ekron. La otra inscripción dice: «Para el santuario», lo que prueba que había un santuario o templo en Ekrom, al que se ofrecían ofrendas y tenía un sacerdocio. Se hallaron en el edificio auxiliar del templo, en la zona noble, seis altares de incienso de cuatro cuernos. Otros dos se encontraron en las dependencias domésticas y nueve en la zona industrial, asociada al aceite, que demuestran que su uso era variado. Estos altares y objetos de culto prueban que había una especie de conservación y dualidad en las prácticas de culto del siglo VII a.C., en Ekrom. Incluyen cultos privados y públicos en áreas profanas. Había un sistema de culto centralizado y descentralizado al mismo tiempo, así como tradiciones locales y forasteras en la práctica religiosa. Los cultos en Ekrom en el siglo VII a.C., continuaron siendo filisteos. Cocluye S. Gitin su exposición señalando la influencia de los contactos con los cultos exteriores fue considerable. Se observa una alta aculturación, un culto multifacético. El rey que construyó el templo se consideraba griego. La diosa, a la que el templo estaba dedicado, era, igualmente, griega, reflejando el lugar de procedencia de los filisteos, el Egeo. El influjo fenicio se detecta en la lengua, en la escritura y en las fórmulas de dedicación del templo; al igual

47 1Sam 6.17. 
que en la arquitectura del templo, mientras que las casas y el templo acusan características de la arquitectura neoasiria.

T. Dothan ${ }^{48}$, del instituto de Arqueología de la Universidad Hebrea de Jerusalem examina la interacción cultual del Egeo y Oriente.

Comienza el autor señalando que la cultura material y la arquitectura hallada en los asentamientos filisteos de Palestina, demuestran que los filisteos intentaron recrear su medio familiar, originario del Egeo, en su nuevo ambiente palestino, llevando consigo no sólo los objetos, sino el conocimiento, las tradiciones y hasta los artesanos. Esto último es más claro no sólo en la cerámica hecha sobre el lugar, Micenica IIIC, sino en la elegante vajilla de mesa y en la tosca, en las terracotas zoomorfas, generalmente de toros, y en las figuras antropomorfas. La arquitectura doméstica de los filisteos es menos conocida. Los edificios de culto y los públicos, en los lugares filisteos reflejan vigorosamente la arquitectura de Chipre y del Egeo, como la planta del megaron y otras características como los hogares rectangulares y otros elementos: bañeras, pilastras y estelas. Las preferencias gastronómicas de los nuevos colonos, que llevaron con ellos, queda bien clara con el aumento del número de huesos de cerdo y de ganado hallados en los lugares ocupados por los filisteos, que sugieren la introducción del cerdo y de la vaca en lugar de la cabra y del cordero.

Las excavaciones en la pentápolis filistea han proporcionado un gran número de datos, que permiten trazar una pintura más detallada y amplia de la cultura filistea.

Las excavaciones han localizado tres de las cinco ciudades filisteas: Ashdod, Ashkelón y Ekrom. Miqne se identifica con Ekrom gracias a la inscripción real de comienzos del siglo VII a.C. Gaza como Ashdod y Ashkelón retuvieron su antiguo nombre. La quinta ciudad de la pentápolis filistea era Gath.

T. Dothan examina detenidamente los orígenes occidentales de la cultura material de los asentamientos en la filistea tal como se documentan en Chipre y en el Egeo. Las ciudades excavadas en la pentápolis filistea y el asentamiento filisteo y los templos de Sikil Gante proporcionan una gran cantidad de elementos útiles para la comparación e integración de la cultura. La combinación de los hallazgos en la Filistea, reflejan la procedencia egea y chipriota, muestran los intercambios culturales que introdujeron elementos extraños en Canaán y su deseo de mantener el ambiente del Egeo, incorporando elementos de la cultura material local. Para el conocimiento de la interacción del culto entre el Egeo y el Oriente, en los objetos y en la arquitectura, varios lugares son claves, como Micenas, Pilos y Tirinto en Grecia; Phylakopi en Melos; Elysos en Rodas; Kastelli-Khania y Vronda-Kavousi en Creta y, principalmente, Enkomi, Kition, Maa-Palaekastro y Alassa en Chipre, que con cabezas de puente para Oriente.

48 Dothan, G. 2003: «The Aegean and the Orient Cultic Interactions», en DeVER W. G., Gitin S. (eds) 2003, op. Cit., 189-212. 
La importancia de los edificios de culto en Ekrom deriva de la fecha inicial de los asentamientos filisteos en el siglo XII a.C. La naturaleza del lugar de culto de estos edificios y de las habitaciones, está indicada por la combinación de características arquitectónicas asociadas a los objetos y a otros hallazgos. En el corazón de la ciudad se han excavado una serie de capillas y de edificios monumentales que muestran una continuidad de la función del culto desde la fase inicial del asentamiento, a comienzos del siglo XII a.C., construido directamente sobre la capa de destrucción del asentamiento abandonado en la Edad del Bronce Medio, a través de cada fase sucesiva de la Edad del Hierro I.

La primera fase de ocupación está representada en el estrato VIIB, por una habitación, 357. Con posterioridad al estrato VIIA, otra habitación, 352, se construyó al sur. El área llegó a estar densamente poblada, con las habitaciones del estrato VII añadidas a un antiguo edificio del estrato VI, siglos XII-XI a.C., En la primera mitad del siglo XI a.C., sucedió un cambio dramático, cuando el templo filisteo 350 fue construido sobre el estrato VI. Este monumental edificio incorporó elementos arquitectónicos e instalaciones, como una entrada tipo megarón y un bamah. Estos elementos y los objetos de culto prueban la consolidación y continuidad de las tradiciones egeas con la incorporación de elementos cananeos. La planta del área continua a través del estrato IV, fechado en la segunda mitad del siglo XI a.C., con algunas modificaciones hasta la destrucción y abandono a finales del siglo XI a.C., o comienzos del siguiente. Estos santuarios superpuestos demuestran la existencia de un área sacra. No hay evidencias de destrucción hasta la que aparece en el estrato IVA. Hay evidencia de transferencia y reutilización, como un par de marfiles, uno hallado en el estrato $V$ y otro en el IV y una estatuilla de mandril fabricada en piedra, encontrada en un escondite del estrato IV/IVA. Después de un vacío de 250 años, siglo vII a.C., es interesante el templo seol, en el que se halló una dedicatoria escrita, lo que sugiere la continuidad en un lugar sagrado.

El especial carácter de las edificaciones del centro del estrato VII queda indicado por las técnicas de construcción, por las características arquitectónicas, por las instalaciones y por los artefactos. La cerámica del estrato VII es local, monócroma y micénica IIIC:1b. Son muy significativos los vasos zoomorfos fabricados en la localidad, asociados a estas u otras capillas. Se trata de un toro al galope, que es una reminiscencia de los vasos en forma de toro del Egeo, del estrato VIIB, y un askos en forma de pájaro en miniatura, procedente del estrato VI. Más significativo, en el estrato VII, es un hogar de una habitación común, con claros paralelos en Chipre. Los hogares rectangulares están fabricados de ladrillos de barro y de arcilla, pavimentados con guijarros, y en algunas estancias con tiestos.

La técnica de los hogares pavimentados y otras superficies con tiestos, llevan a Chipre y al Egeo, Athiescou, Enkomi, Tirinto, no es cananea. Esta técnica se documenta en los hogares rectangulares de Ashdod, de Ashkedón y de Tell Qasile. Es significativo, igualmente, la combinación, en habitaciones de culto, de pilares flanqueando el hogar, de bancos y de otros objetos añadidos, ajenos a la tradición 
cananea. Estas habitaciones tienen paralelos en Enkomi, entre otros lugares, y en Micenas. Una variante del hogar se halló en Tell Qasile XII y en Enkomi.

Los pavimentos de guijarros fueron usados en hogares rectangulares. Una importante característica que en el área filistea es única, en Ekrom, es el hogar de guijarros. Este tipo de hogar aparece en varios contextos y lugares en las primeras fases de asentamiento en el estrato $\mathrm{VII} / \mathrm{VI}$, como los trece hogares excavados en el estrato VI. La construcción doméstica alargada, 404, tenía quince pequeños y redondos hogares. En uno de estos hogares aparecieron un cáliz y un vaso zoomorfo de forma de toro, de características típicamente filisteas. Este tipo de hogar en un claro contexto de culto, aparece sólo en el estrato V. El eco de estos hogares se documenta en el megarón de los palacios de Micenas, de Tirinto y de Pylos, donde se halló un tipo similar de hogares de guijarros reducidos a capillas populares de diferentes plantas arquitectónicas, que reflejan aspectos de las tradiciones micénicas. Queda claro, después de la destrucción del palacio de la ciudadela superior de Tirinto, que la habitación con megarón se reconstruyó en pequeño, y la cerámica que tenía, es diferente a la micénica IIIC:1b. Estos hallazgos indican que el asentamiento del periodo post-palacial, no sólo estuvo en la ciudad baja, sino en la acrópolis.

Importantes ejemplos de elementos arquitectónicos, de combinaciones de estos elementos y de otros hallazgos que reflejan tradiciones egeas, llegaron a la Ashdod filistea. En el área $\mathrm{H}$, un complejo arquitectónico del siglo XII a.C., con características especiales, se excavó en el estrato XIII-XII, que es la fase primitiva del asentamiento filisteo. Esta estructura incluye muros reconstruidos y reutilizados de la Edad del Bronce Final en algunos lugares, y fue construido directamente con los restos de la ciudad cananea de la Edad del Bronce Final.

La unidad más meridional de este conjunto es una estructura absidial con su edificio 5233, posiblemente en un atrio que carece de paralelos en la Filistea. Los absides que se documentan en el Egeo, en los siglos XII-XI a.C., pudieron tener una función cultual. Estos edificios, al contrario de Ashdod, son libres, como en Legkandi, donde los huecos para los pilares de madera, se han hallado alrededor de las estreucturas. En Ashdod, el espacio dentro de la estructura absidial, ha dado cerámica micénica IIIC:1b, como fragmentos de un kalatos. El edificio 5337, tenía un hall con un hogar rectangular y dos pilares. Ha proporcionado cerámica bicrome filistea y micénica IIIC:1b, y ciertos hallazgos especiales, como fragmentos de cuatro figurillas de tipo Ashdod, cuencos de pájaros y cuentas. La habitación nordeste tenía un banco hecho de ladrillos de barro, cerámica filistea y una gran cantidad de hallazgos, como dos discos decorados según el estilo egeo, un amuleto de fayenza y cuencos en miniatura; cuentas, marfiles decorados y un kylix en miniatura, micénico IIIC:1b. Un banco parecido se descubrió al mismo nivel en la habitación nordeste, que dio cuencos micénicos IIIC:1b y ceámica bicrome flistea, hallazgos especiales que incluían un cascabel en forma de ave, un jarro de cerveza, una placa cuadrada de marfil, y un botón de marfil de forma de roseta, así 
como otros marfiles y objetos de bronce. La planta arquitectónica de este edificio, incluyendo un gran hall flanqueado por varias habitaciones es tipico de la filistea Ashdod y aparece en el mismo estrato en el área G. Plantas de semejante arquitectura halladas en Grecia en el siglo XII a.C., indican un origen del Egeo, como la casa $G$ de Chipre, que consta de un hall con dos pilares, de un banco y de hallazgos de un culto de la naturaleza, que ha sido interpretada como un santuario. Las casas de Panogia situadas fuera de la muralla de Micenas son un paralelo próximo. Una casa con una gran habitación, con hogar rectangular y dos pilares, es semejante al edificio 5337 de Ashdod, y a estrato VII construido en el campo IV de Ekrom, se data antes que el complejo de Ashdod. Continúa usándose en el siglo XII a.C. Una figurilla de Ashdod, sentada hallada en el estrato XI se ha encontrado en las proximidades del área $\mathrm{H}$ de Ashdod. Unos músicos que tocaban en el culto y otros recipientes sugieren una función cultual, se han recogido en este área del estrato X, seguida de la destrucción del estrato XI, fechada, probablemente, a finales del siglo XI a.C. Es otro buen ejemplo de continuidad de uno de los lugares sagrados para el ejercicio del culto. El conjunto no funcionaría como una capilla. Es diferente del santuario de Ekrom y de los templos filisteos de Tell Qasile. Un avance en las relaciones de culto, entre Filistea, Chipre y el Egeo, llegó con los recientes hallazgos de varias bañeras procedentes de diferentes lugares de la pentápolis filistea. Un larnax de terracota se excavó en un conjunto arquitectónico distinguido en el tell superior de Ashdod, area G del estrato XII. La cerámica IIIC:1b hallada en este edificio procede de la primitiva fase del asentamiento filisteo. La gran habitación común, el megarón, tenía una bañera de terracota, próxima a un hogar rectangular.

La bañera de Ashdod tiene paralelos cercanos en muchas bañeras de terracota procedentes de Chipre. En Micenas, una bañera de terracota se halló en un contexto de culto, en la pendiente oeste. Esta área de culto comprendía el templo de los ídolos, con bañera oval en el centro. No hay duda que era un lugar de culto. Interesante es un trozo de bañera de terracota, hallada en Tell Qasile, en el asentamiento primero del estrato XII-XI.

Otro tema fundamental del área de la falda de Micenas, que atañe a este problema que se trata, es una serie de capillas de una gran y bien planeada construcción monumental. Este fenómeno se repite en la parte baja de la ciudadela de Tirinto.

Las características de tales capillas se relacionan con las datadas en las primeras fases del asentamiento filisteo en Ekrom.

Los ejemplos más completos de los templos filisteos son los de Tell Qasile, en los límites de la Filistea, datados en una fecha ligeramente posterior a las primitivas habitaciones de culto de las capillas en Ekrom y en Ashdod. El proyecto de Tell Qasile es diferente y la ausencia de la fase inicial del micénico IIIC:1b es típica de las ciudades de la pentápolis. La cerámica filistea bicrome representa la primera fase de ocupación. 
Otro elemento importante son tres bañeras de piedra de diferentes características halladas en Ekrom y Ashkelon. En una habitación había un baño, un hogar cuadrangular en el centro, una bañera de piedra pegada a la pared y abundante cerámica micénica IIIC: 1 b.

Esta habitación era parte de un gran complejo bien construido, vinculado a la fase inicial del asentamiento filisteo del siglo XII a.C. Una bañera parecida de piedra se halló en una gran habitación en el estrato VIA, edificio 353, datada igualmente en la primera fase del asentamiento filisteo, próxima a un hogar rectangular, con un monolito en el centro de una habitación alargada. Las Dimensiones de la bañera son aproximadamente $1 \times 60 \mathrm{~cm}$, y tiene una abertura para sacar el agua fuera. En Ashkelon ha aparecido una bañera de piedra, bien trabajada, colocada en una gran habitación, que también contenía un hogar. Se fecha en la primera etapa del asentamiento. El ejemplo de Ashkelon ilustra la existencia de purificaciones de la comunidad o de áreas rituales, caracterizadas por la presencia de bañeras y de hogares en habitaciones.

Bañeras de piedra se conocen tres ejemplares en Enkomi. Una es semejante a la de Ashkelon. El carácter ritual de la bañera puede quedar probado por la presencia de una de ellas en piedra, que no sirve de ataúd, en una tumba de Palaepaphos. En el siglo XII en Chipre, son numerosas las bañeras de terracota y de piedra, en contextos claramente de culto, crematorios, habitaciones de baño asociadas a hogares, o pilares de piedra y bancos. En la Filistea las bañeras en habitaciones, que tenían hogares, y otros hallazgos vinculados al culto parecen indicar que se usaban en rituales de purificación.

En Ekrom se conocen otros ejemplos de habitaciones y edificios, que ilustran las connotaciones del culto y las conexiones con Chipre y con el Egeo. Un buen ejemplo procede del campo $X$, que ha dado habitaciones adyacentes a las fortificaciones en la periferia oeste del yacimiento y ha proporcionado hallazgos de la fase inicial del poblado. En una habitación se ha recogido un banah y un depósito de fundación con una crátera micénica IIIC:1b y una lámpara. Otra habitación ha proporcionado un conjunto de vasos decorados, micénico IIIC:1b de la fase inicial del asentamiento, un vaso de libación de forma de erizo, de factura local y con un estilo decorativo característico del micénico IIIC:1b. El vaso en forma de erizo tiene muchos paralelos en los vasos de culto micénicos IIIB. Principalmente se trata de importaciones de Levante. Es interesante señalar que el erizo de Ekrom es el único vaso micénico IIIC de este tipo hallado hasta el presente. Son bien conocidos como vasos de libaciones, en el Egeo, en Chipre y en Ugarit. Otro hallazgo bien conocido en la cerámica micénica es un askos de forma de pájaro, recogido en una habitación de culto. Estos vasos tienen un origen en el Egeo, donde se encuentran en enterramientos y en contextos de culto, pero son de fabricación local. Poseen también un gran interés unas figurillas micénicas IIIC en miniatura, que son réplicas de originales micénicos.

Estos objetos desempeñaban un papel importante en los enterramientos y en las prácticas de culto. Un ritón en forma de león, hallado en Ekrom, llegó de Tell el- 
Safigath. Estos objetos de culto son bien conocidos en la Filistea. Un conjunto se halló en la favissa de Tell Qasile y en el Egeo. Incluso las escápulas halladas empotradas en el suelo enlucido de blanco en una capilla de Ekrom, tiene paralelos en la Filistea, en Ashkalón, en Sikil Dor y en otros lugares de los Pueblos del Mar, y son parecidas a las de Chipre halladas en Kition y en Enkomi.

Se pueden mencionar otros hallazgos de estas relaciones de culto. El templo filisteo, edificio 350, ha proporcionado una navaja de hierro con mango de marfil con ribete de bronce, y un segundo mango de marfil con huellas de hojas de hierro asociadas ambas a un banot, un doble pivote con doble cabeza, tres ruedas en miniatura, fragmentos de una esquina de bastidor y un pendiente de forma de capuIlo, todo fabricado en bronce. El pivote estilísticamente se vincula en Chipre asociado a elementos egeos en trabajos chipriotas de bronce. Los mangos de navaja de marfil con restos de hojas de hierro, se han hallado en Enkomi. Navajas parecidas han aparecido en Israel, en Tell Qasile y dos en Sikil Dor.

Es importante su vinculación con objetos depositados en las capillas. Los objetos de hierro son escasos y apuntan a Chipre y al Egeo. Llegaron desde el oeste al este.

T. Dothan termina su importante artículo mencionando la aparición de un sustrato en los centros urbanos de Filistea que hechó raíces en la tradición egea, que fue adoptado en el nuevo ambiente en Canaan y aceptó aspectos de la cultura cananea. Las connotaciones de culto ilustran el fenómeno de la arquitectura pública con hallazgos como el megarón incorporado y la configuración de las características, tales como hogares, bañeras, pilares, bancos, vinculados a cerámica y a otros hallazgos de especial valor, como figurillas de terracota, vasos zoomorfos, objetos de bronce y de hierro, marfiles y objetos de lujo.

Concluye T. Dothan, cuyo artículo hemos seguido detalladamente, que todos estos componentes caracterizan una civilización urbana altamente sofisticada en las ciudades del Hierro I en la pentápolis filistea.

Es fundamental recordar que los israelitas mantuvieron relaciones intensas con esta cultura, fueron frecuentes las guerras en las que la superioridad filistea se basaba en las armas de hierro ${ }^{49}$. Según la tradición bíblica, posiblemente falsa, Saúl (1020-1004 a.C. $)^{50}$, murió en lucha con los filisteos ${ }^{51}$. Los israelitas adoraron, según la Biblia, los dioses de los filisteos. Se conocen los nombres de dos, Baal-Zabub, que tenía templo en Ekrom ${ }^{52}$ y Dagón, que lo tenía en Gaza ${ }^{53}$. David (1004-965 a.C.) guerreó varias veces con los filisteos ${ }^{54}$, se apoderó de sus ciudades ${ }^{55}$. Los fi-

\footnotetext{
49 1Sam. 13.2.

50 1Sam. 14.47.52.

51 1Sam. 31.10.

52 2Re. 1.2.

$53 \mathrm{Ju} .16 .23$.

54 2Sam. 5.17-25; 23.9-12.

55 2Sam. 8.1.12; Cro. 18.1.
} 
listeos pagaron tributo al rey de Judá, Josafat (867-846 a.C.), y hasta se llevaron los bienes del rey, sus hijos y mujeres. Los filisteos aparecen aliados de los árabes $^{56}$. Ozzías (767-733), rey de Judá, desmanteló varias ciudades de la pentápolis filistea y construyó ciudades en territorio filisteo ${ }^{57}$. El reino de Judá en tiempos de Ajaz (758-727 a.C.), sufrió incursiones de los filisteos ${ }^{58}$. Ezequías los batió hasta Gaza, ciudad de la que se apoderó. Los filisteos, según los archivos asirios, fueron dominados por Tiglat-Pileser III (745-727 a.C.), por Senaquerib y por Sargón II. Desaparecido el Imperio Asirio cayeron en poder de los egipcios y de los persas.

S. Stern ${ }^{59}$, del Instituto de Arqueología de la Universidad hebrea de Jerusalem, examina el origen fenicio de los cultos palestinos al final de la Edad del Hierro. Comienza su autor su trabajo recordando que en el período de la monarquía había siete naciones en Palestina. La octava, los arameos de la tierra de Geshia, habitantes del noreste de Israel, fueron deportados por los asirios en 732 a.C., y no volvieron jamás. Las siete naciones son las siguientes:

- Los fenicios habitaban la costa norte. Los filisteos estaban asentados en las ciudades estado de Ashdod, Ashkelón, Ekrom y Gar.

- Al este del Jordán se encontraban los Ammonitas, los moabitas y los edomitas.

- Judá.

Estas siete naciones, durante la Edad del Hierro tenían cada una su culto independiente que consistía en la adoración de un par de dioses mayores. Cada dios masculino tenía un nombre que le distinguía. La mayoría están mencionados en la Biblia.

El dios de los arameos era Haddad, el de los fenicios Baal, los de los filisteos Dagón y Baal, el de los amonitas Milcom, el de los moabitas Chemosh, el de los edomitas Gos y el de los israelitas y el de Judá, Yahweh. La diosa para todos, incluso para los israelitas y para Judá era Astart o Asherah.

Las imágenes de los dioses eran diferentes. Al final de la monarquía las representaciones de las diversas deidades estaban consolidadas. Los arqueólogos 0 los especialistas atribuyen las imágenes a los cultos fenicios, filisteos y de Judá. Los varios objetos religiosos, a pesar de las diferencias de culto y de dioses, son muy uniformes. Todas las naciones usaban los mismos objetos de culto, altares de incienso, de piedra o de arcilla, incensarios de bronce o de arcilla, soportes de culto, y quemadores de incienso, calices, copas, varillas de bronce o de marfil, adornadas con granadas, etc.

${ }^{56}$ 2Cro. 21.16-17.

57 2Cro. 26.6-7. $2 \mathrm{Re}$

58 2Cro. 28.18.

59 STERn, S. 2003: «The Phoenician Source of Palestinian Cults at the End of the Iron Age», en DEVER W. G., Gitin S. (eds) 2003, op. Cit., 309-322. 


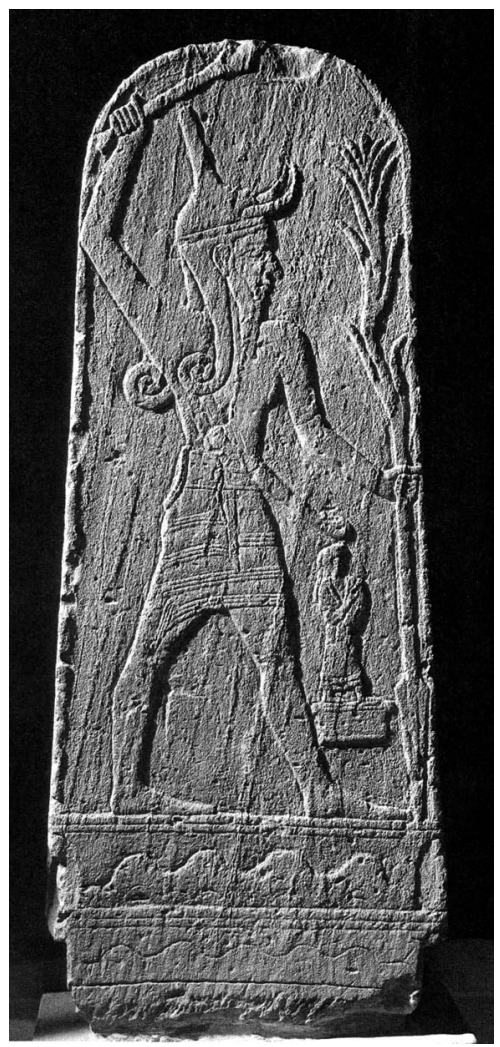

Figura 3: Estela de piedra caliza procedente de Ugarit, en la que aparece representado el dios Baal.

Los recipientes de culto de un dios podían servir para otro, como lo prueba la estela de Mesha, en la que el rey de Moab envía los vasos sagrados de Yahweh tomados en la ciudad de Nebo (Judea), al templo de Chemosh.

La tesis que propone E. Stern, que los cultos practicados en Palestina durante la Edad del Hierro en las seis naciones: israelitas, judíos, filisteos, amonitas, moabitas y edomitas fueron casi idénticos, y todos ellos procedían del culto fenicio, continuando la tradición más vieja cananita.

\section{EL CULTO FENICIO}

Se han excavado pocos santuarios fenicios y menos aún datados en la Edad del Hierro. Los santuarios fenicios de la costa Palestina son en su mayoría de la época persa. Los santuarios fechados en la Edad del Hierro son los de Kition en Chipre, pero E. Stern no los estudia en su trabajo. El único santuario de la Edad del Hierro es el templo I de Sarepta, descubierto en el barrio de los ceramistas. Sobre 
él se contruyó un santuario en el periodo persa. El templo 1 es de planta rectangular, con piso de cemento y orientado en dirección este-oeste. A lo largo de las paredes corría un banco. En la pared oeste se colocó una mesa, probablemente para poner sobre ella ofrendas. Enfrente había una gran piedra de sillería. Un hueco en el suelo parece indicar la presencia, en este punto, de una estela o de un altar para quemar incienso. Cercanas a la mesa se encontraron unas figurillas de arcilla, máscaras, también de arcilla, marfiles, medallones y lámparas. La planta de los dos santuarios conserva la vieja tradición cananea. Es casi idéntico a los templos cananeos de la Edad del Bronce Final, como los templos de Laquish, Beth-Sehean y otros. Estos templos recuerdan a algunos del Bronce Medio como a uno de Wahariyah.

Últimamente se han descubierto unas pocas capillas de oración, que son una habitación. Continuan un viejo concepto cananeo, como en el templo del área $\mathrm{C}$ de Azor. Corrientemente, esta habitación contenía la imagen del dios o de la diosa y, a veces, una estela de piedra. Capillas parecidas han aparecido en otros lugares, como al pie de Tel Michal, datada en el siglo x a.C., y en la puerta de la ciudad de Tel Dan. Otras muchas capillas se han descubierto en los asentamiento fenicios del oeste, al igual que en ultramar y, recientemente, en fortalezas de Judá, como en Rowat-Radum, Vered Jericó, Mezad Michmash y en la ciudad aramea de BethSaida, etc.

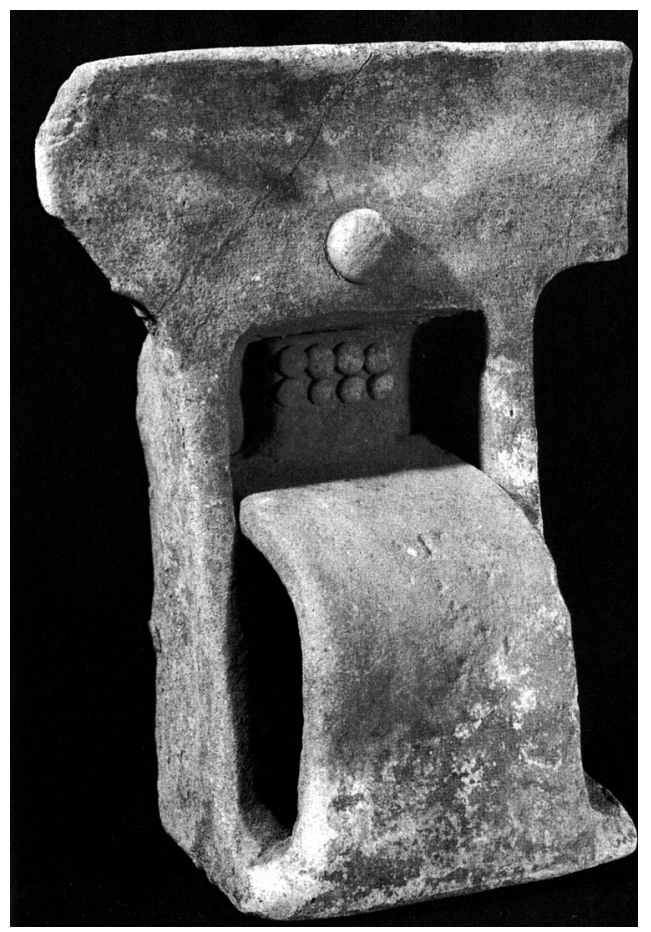

Figura 4: Modelo de terracota de un altar fenicio. Siglo I. Museo de Israel. Jerusalem. 
E. Stern cree rastrear la existencia de fuentes bíblicas y griegas en la práctica de culto de los santuarios fenicios. Entre las fuentes fenicias escritas halladas en las excavaciones, hay varias inscripciones, la mayoría del periodo persa. La más larga es un ostraca de Acco procedente, probablemente, del lugar del santuario. Se trata de una orden emanada por la autoridad de la ciudad, dirigida al gremio de los trabajadores de metal, para entregar a la persona nombrada, como el jefe del santuario, un cuenco de metal precioso, y además un número de objetos de metal, fabricados de oro o de plata. Los nombres de unos pocos de estos objetos son griegos, pero están recogidos en escritura fenicia.

Una inscripción parecida, pero más antigua, está incisa en un cuenco barnizado de rojo, hallado en uno de los templos de Kition, Templo I, fechado en los años 850-800 a.C. Esta inscripción menciona a un ciudadano de Tomsassos, en Chipre, que va al templo en Kition a ofrecer su pelo, colocado en un cuenco dedicado a Astart. Otro testimonio de esta tradición es otra inscripción, recientemente hallada en Kition, que menciona al personal del templo de Astart en la ciudad. Entre los empleados del santuario se encuentran los barberos sagrados. En la misma inscripción se alude a otros funcionarios del templo, como escribas, metalúrgicos, policías, chiquillos y otros. Se conocen listas de objetos de culto, especialmente en inscripciones de Kition, que incluyen docenas de objetos de metal, la mayoría hechos de cobre. La lista de la tarifa de Marsella que, probablemente, procede de una de las colonias próximas, se ha vinculado con el templo de Baal Safón; incluye los precios de varios animales, ofrendas al templo. Son parecidas las listas bíblicas. Detalles adicionales se pueden hallar en muchas inscripciones en estelas de piedra, que aluden a objetos parecidos. Queda claro que los cultos del Mediterráneo occidental son los cultos practicados por los fenicios a lo largo de su país y de la costa Palestina, en Chipre y en las colonias occidentales.

\section{LA NATURALEZA DEL CULTO FENICIO. SUS SÍMBOLOS Y SU PERVIVENCIA}

Por lo general, los hallazgos arqueológicos se componen de dos tipos de figurillas que aparecen en todos los conjuntos. Un varón representado como un rey en un trono o de pie, o como guerrero a caballo, y una diosa sentada en un trono, o como diosa de la fertilidad enseñando los pechos, o mujer embarazada, o mujer amamantando a un niño.

Recoge E. Stern el pensamiento de Moscati sobre el culto fenicio, que estaba compuesto de una tríada de divinidades: un dios protector de la ciudad; una diosa o compañera, que simboliza la fertilidad de la tierra; un dios joven, vinculado con la diosa, generalmente hijo, cuya resurrección expresa el ciclo anual de la vegetación.

Los nombres y las funciones de los dioses varían. Es característica de la religión fenicia la fluidez de este panteón. El nombre común prevalece sobre el nom- 
bre propio, y la función sobre la personalidad. Otra característica de la triada fenicia es su fexibilidad de ciudad a ciudad.

La fuente arqueológica más importante para el conocimiento de la religión fenicia son los cientos de inscripciones halladas en el oeste mediterráneo, en las que se mencionan un par de dioses, uno masculino y una diosa. El nombre del dios frecuentemente es doble, Baal-Melqart, Baal-Eschnun, Ashtoreth-Tanit, etc. Raramente las inscripciones mencionan el nombre de otra deidad.

Baal es el dios masculino, es un teónimo que aparece en cientos de nombres personales, incluso en el nombre de reyes y de altos funcionarios fenicios como Adomibaal, Elibaal, Baalnatan y otros. Los israelitas, judíos, filisteos, moabitas, edomitas y ammonitas también añadían el nombre de su dios. Se incorporaban tambien epítetos que indicaban sus atributos o su función, como Baal Shamain, es decir. «Baal del cielo», escrito en un papiro del 604 a.C. Algunos epítetos son de regiones geográficas, como montañas sagradas: Baal Carmel, Baal Lebanon y Baal Zafón; otras veces son el nombre de una ciudad o de una colonia: Baal Sidón., Baal Tiro, Baal Gwalat.

El nombre Baal se aplica a dioses de otras naciones de Palestica, cada una con su dios particular, incluyendo una adoración en el culto de Israel y de Judá. Baal recibe muchos títulos de glorificación, como Molekh, «rey», o Adon, «Señor». Estos títulos se usan en todas las otras naciones de Palestina.

La consorte de Baal es Ashtoret, que se encuentra en muchos nombres de hombres, como Ebed-Astart, «sirviente de Astart», o Em-Astart, «madre de Astart». Otros nombres, al igual que en el caso de Baal, aluden al territorio: Astart Sidon, Astart Libanon. En ocasiones también aparece el nombre de su consorte como «Astar, el nombre de Baal», o «Astart, la esposa de Baal».

Se conocen epítetos como dama aplicados a Astart. En la Edad del Hierro Final, cuando se consolidaron las relaciones con Egipto, se documenta frecuentemente el influjo egipcio en el culto fenicio en particular, y en los cultos palestinos en general. Es el caso de la Ishtar-Chemos de Moab. Imágenes de los dioses egipcios se introdujeron en los cultos locales. La presencia de Isis se documenta en BaalatGwal, en la estela del rey de Biblos Yehaumilk. Osiris se incorporó también al culto fenicio. Este fenómeno se refleja en las listas egipcias de nombres fenicios que, frecuentemente, incluyen dioses egipcios como Ebed-lbsat, "sirviente de Bastet» que es una diosa egipcia.

A veces las inscripciones fenicias mencionan a Isis. Es frecuente el uso de figurillas egipcias o locales que son imitaciones halladas en las naciones palestinas, donde penetran a través de los fenicios. Los objetos de culto más frecuentes son las figurillas de arcilla, aceptadas por todas las naciones de Palestina, incluyendo Judá. Son figurillas, principalmente femeninas, desnudas, sosteniendo los pechos con las manos, que cubren su cabeza con una larga peluca fenicia. El cabello cuelga hasta los hombros. La peluca es diferente de la peluca corta que usaban a 


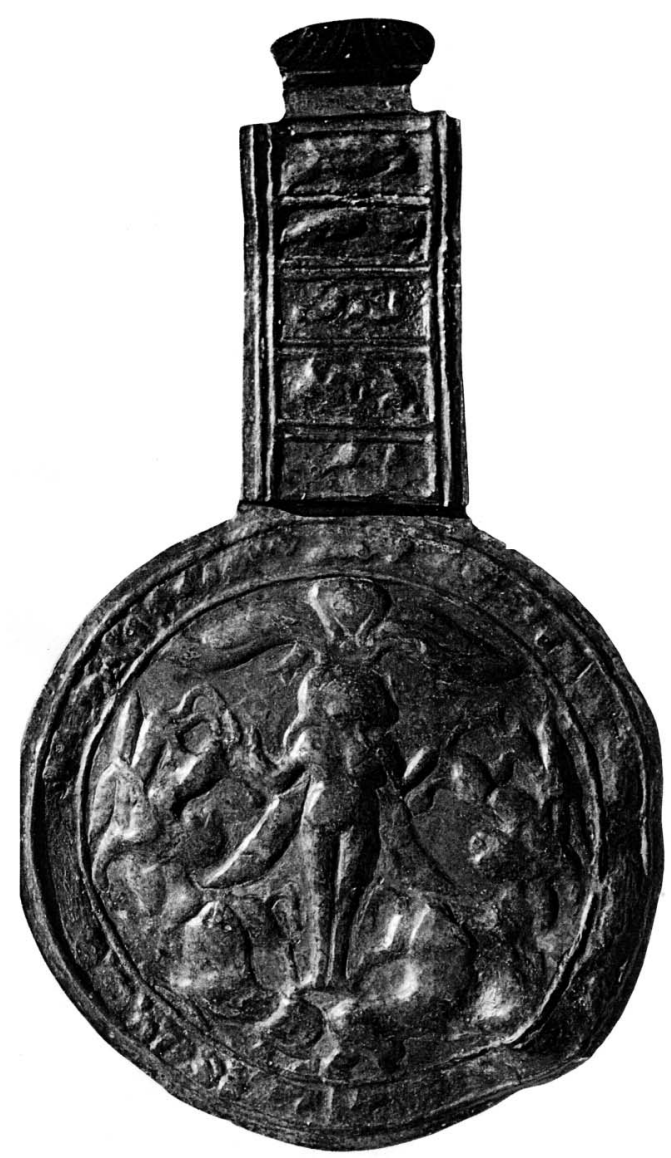

Figura 5: Ornamento de caballo. En la parte central aparece representada Astarté. Finales del s. VIII a.C. Museo de Chipre. Nicosia.

final de la Edad del Hierro. En su fabricación, tanto en el caso de las masculinas como las femeninas, se emplea una técnica llegada de Grecia.

Las características de las figurillas fueron cambiantes; a las damas sosteniendo sus pechos, se unen otras en avanzado estado de gestación, con una mano colocada sobre el vientre; en un número no muy numeroso van unidas a un muchacho, bien alimentándole, jugando con él, o llevándole de los hombros. Frecuentemente no van acompañadas de inscripciones. Unas figurillas halladas en una excavación submarina de las proximidades de Shanei Zion representan a la diosa Tanit, a Pane-Baal o a un delfín. Según las inscripciones de Sarepta, Tanit y Astarté son la misma diosa.

Unas figurillas de arcilla representan músicos tocando sus instrumentos. La mayoría están fabricadas con la técnica fenicia y van cubiertas con peluca egipcia, 
y, en lugar de adoptar las posiciones que mencionábamos con anterioridad, sostienen en sus manos cuatro tipos de instrumentos musicales diferentes: lira, doble flauta, pandereta o tambor. Las figurillas recogidas en Fenicia llevan, generalmente, estos cuatro instrumentos musicales, como en Achzib, Sarepta, Acco, Tell Keisan, Tel Megadin, Dor, Siqmona, también en Chipre y en las colonias púnicas. El tema se repite en los marfiles fenicios, en los cuencos de metal, también fenicios, así como en las estelas fenicias y de Israel. Este motivo obedece a prototipos fenicios. Fue introducido en los santuarios de Israel y de Judá, como otros cultos locales $^{60}$. En Israel se han hallado figurillas de músicos con los mismos instrumentos, en Hazor, Dan, Taanach, Beth-Shean y Tirzah; en Judá; en la Filistea y en todos los reinos de Transjordania. Otras veces son hombres de las montañas, como tocador de la pandereta en Tel'Ira, en Judá, un tocador de arpa en Ashdod, un tocador de flauta en la edomita Tel Malhata.

Un tercer grupo de figurillas femeninas hallado en Achzib y en varias localidades de Chipre y del mundo púnico, representa a mujeres dedicadas a actividades de la vida diaria: lavándose en un baño y amasando pan en una mesa.

Según E. Stern, no está claro si estas figurillas representan actividades de culto, como los músicos, o trabajos de la vida diaria. Unas pocas figurillas son de marfil, como las encontradas en Achzib, Dor y Sarepta. También se conocen figurillas en metal. Los sellos y las impresiones de sellos son numerosos en la Edad del Hierro.

Un interesante aspecto es la identificación entre las fencias Astar e Isis. En la glíptica fenicia Astart aparece como una deidad fenicia, en la inscripción no se diferenciarían las dos diosas. Ya se mencionó la estela de Yehaumilk, donde Astart está representada como Isis. Se conocen muchos amuletos y figurillas de la diosa egipcia, encontrados en templos fenicios y en favissas de ciudades palestinas, como en Dor, Atlit, Ashkelon, Tel Michal, etc. Son escasas las figurillas de varón. Salvo los músicos, sólo se documenta el jinete, que representa al dios guerrero. Jinetes de tipo fenicio se han descubierto en tumbas y casas de Achzil, Kabu, Tel Keisan, Acco, Megiddo, Dothan, Tel Megadim, Dor y Shiqmona. Los jinetes llevan un yelmo puntiagudo, reminiscencia del dios egipcio Osiris, y pueden considerarse como representaciones del dios. Figurillas parecidas se han encontrado en ciudades de la costa sirio-fenicia y en Chipre. E. Stern piensa que pueden interpretarse como Baal guerrero. La única otra figura masculina fenicia viene del templo de Sarepta, donde se recogió una cabeza con turbante, de un tipo frecuente en otras naciones palestinas, en Judá y entre los ammonitas. Las figuras fenicias estaban pintadas con colores vivos, principalmente rojo y negro, acentuando los detalles de la cara en los varones y de los caballos.

60 1Sam. 10.5. 


\section{COMPARACIÓN DEL CULTO FENICIO Y DEL CULTO DE JUDÁ.}

Esta parte del estudio de E. Stern es de una importancia excepcional. En Judá se construyeron numerosos santuarios, que recibían el nombre de Casa de Yahweh. El más importante y central fue levantado en Jerusalem en una colina que luego sería conocida como Monte del Templo. El Antiguo Testamento menciona otros santuarios en Dan, Bethel, Shiloh y Beersheba61.

En la fortaleza de Arad se excavó un santuario de Judá. Es un ejemplo de todos los santuarios de este periodo y de todos los templos de Judá. El santuario de Arad consta de tres espacios, un ulam, un heïchal y un debir. Su orientación es de este-oeste. En la parte central, el ulam, tres escalones conducen al santa santorum, que es una plataforma algo elevada. Un massebot se halló en el nivel de destrucción, y otros dos estaban embutidos en la pared del santa santorum, uno en uso en la fase final del santuario. En la tercera zona, dos altares piedra, para quemar incienso, llevan las huellas de haber quemado materiales en la parte superior, probablemente el incienso. En el atrio había un gran altar construido con ladrillos de arcilla. El excavador del santuario, Aharoni, llegó a la conclusión de que la planta y su contenido eran las de un templo dedicado a Yahweh de Juda.

En otras fortalezas de Judá se han hallado otras instalaciones de culto, plataformas de culto con escalones, que llevan a las puertas de la fortaleza, como en 'Uza y Radum, cerca de Arad. En las proximidades de la puerta de la fortaleza de Judá en Beersheba, se ha encontrado otro banah, en el que se recogió un altar de piedra, de cuatro cuernos. Una instalación parecida, identificada como un banah de culto, se halló en la fortaleza de Judá en Vered Jericó. Varios escalones de piedra, encontrados próximos a la puerta de la fortaleza de Mezad Michmash, en el límite norte del reino, se han interpretado como que conducían a la plataforma sagrada o Banah. E. Stern recoge la teoría de Aharoni, de que casi todas las fortalezas de los límites del reino de Judá tenían centros de culto. Muchas figurillas, altares y objetos de culto se recogieron en casi todas ellas. Se supone que un santuario dedicado a Yahweh había también en Laquish, que era la segunda ciudad en importancia de Judá, pues entre el botín que los soldados de Senaquerib obtuvieron en el saqueo de la ciudad, había un par de grandes lugares de culto, que son del mismo tipo que los modelos más pequeños hallados en muchos lugares de Judá.

Los santuarios dedicados a Yahweh en los asentamientos fuera de Jerusalem fueron numerosos. Baste recordar el famoso lugar de culto de Kuntillet Ajrud, de finales del siglo Ix a.C. consagrado a Yahweh de Samaría y a su Asherah, o a Yahweh de Tenman y a su Asherah. En la estela de Mesha se menciona otro santuario más viejo, en la que el rey moabita incita a tomar los vasos sagrados de Yahweh de la ciudad de Nebo. Y a depositarlos ante Chemosh, lo que indica que existía un santuario consagrado a Yahweh en Nebo, antes de ser la ciudad sa-

61 1Sam. 1.2.4;. 23.15-20; Am. 8.14. 
queada por los moabitas. Muchas inscripciones de este periodo mencionan la Casa de Yahweh. En un ostraca recientemente publicado está escrito: «de acuerdo a la orden dada a ti por Astiyahu, rey, para dar a través de la mano de Lecharyahu, la plata de Tarshish. A la casa de Yahweh tres shekels». Una inscripción sobre una pequeña granada dice: «consagrado al sacerdote de la Casa de Yahweh». En dos ostraca del santuario de Arad se recogen los nombres de dos familias sacerdotales bien conocidas, Mermot y Pashur, que posiblemente actuaban en la Casa de Yahweh.

Los cargos sacerdotales en los santuarios de Yahweh permanecían dentro de las familias de generación en generación, de padre a hijo.

En unos pocos sellos el título de sacerdote se añade al nombre como Helqiah, el sacerdote, que pudo ser sumo sacerdote en Jerusalem. Un sello, fechado al final del reino de Israel, menciona a un sacerdote israelita que trabajaba en el templo de Yahweh en Dor ${ }^{62}$. Amos cita al sacerdote de Bethel. En un sello se menciona a Miqnayahu, sirviente de Yahweh, que sin duda trabajaba en el templo de Yahweh. Sacerdotes podían servir en alguno de los templos del país. En varias excavaciones realizadas en Judá es frecuente ver añadido el nombre de Yahweh como complemento de los nombres.

E. Stern indica, siguiendo a Millard, que aproximadamente de 1200 nombres personales escritos en ostracas y en sellos, 557 están compuestos de la palabra Yahweh y sólo 25 llevan los nombres de otros dioses. El nombre de Yahweh aparece en ostraca de Laquish y de Arad, en otros lugares de Judá y en bendiciones: «pueda Yahweh bendecirte en paz». Otra inscripción de Judá, de la misma época menciona la divina pareja venerada por la población local, Yahweh y Aserah. Estos nombres aparecen en las inscripciones del santuario israelita primitivo de Kimtillet Ajrud y el culto de estos dioses por los israelitas de este tiempo.

Una inscripción de la tumba de Khirbet el-Qom en la región de la colina central de Hebrón cita a Yahweh y a su Asherah. Una tumba de Judá, próxima al lugar de Beth Loya, menciona a Yahweh como señor de Jerusalem y de las montañas de Judá.

Un tipo de objetos de culto, típicos de Judá se documentan con frecuencia. Son figurillas masculinas y femeninas de los dioses Yahweh y Asherah. Estas figurillas se datan desde finales del siglo VIII a.C., a comienzos del siglo vi a.C., y se encuentran por todo Judá. Desde el territorio de Benjamín, al norte, Bethel, Tell enNasbeh, Gibeon, Ramot, Mosa, hasta Jerusalem, Ramat Rahel, Neth-Zur, BethShemesh, Batash y otros sitios del oeste. Al sur de Judá se han recogido en Arad, Tel'Ira, Beersheba, Tel Masos. Se han hallado y en pequeñas fortalezas como Kirbet Alon Tuwein. En Judá y en otros reinos de la Edad del Hierro, la mayoría de las figurillas son femeninas, se identifican generalmente con Astart. A ve-

62 Am. 7.10 
ces tocan el tambor o tienen una paloma que era el símbolo de Astart. Las figurillas de Judá y de Fenicia se pintaban de color rojo, negro o blanco. El color se usaba para resaltar los ojos y el cabello. Las piezas mejores proceden de Jerusalem. Figurillas de Astart halladas en Judá, están fabricadas en diferentes materiales, como marfil o hueso.

Este culto se extendió a todo el reino. E. Stern recuerda que de las 822 figurillas halladas en Judá, 405 proceden de Jerusalem.

Las figurillas masculinas recogidas por decenas en todos los lugares de Judá, no están bien representadas en la literatura. Los dos tipos son el jinete, dios guerrero, que se documenta en otras naciones del país. Las halladas en Judá son únicas por su estilo. En el segundo tipo el varón cubre la cabeza con un turbante. Sólo se han encontrado de este tipo unas pocas docenas. El turbante aparece en el relieve de Laquish y lo llevan los israelitas del periodo asirio en Megiddo y las esculturas ammonitas.

E. Stern sólo se atreve a conjeturar que estas figuras representan deidades. Pueden representar igualmente al fenicio Baal, cuyo culto se introdujo en Jerusalem. También es posible que fueran representaciones paganas del dios nacional de Judá, Yahweh o de su consorte Astart o Asherah, pues estas figuras son únicas en Judá.

Piensa E. Stern que pudo existir un culto, que puede calificarse de paganismo yahwista. El material citado pertenece a este culto mixto, incluye lugares altos sagrados, altares y varias figurillas. Es muy difícil establecer diferencias en lo referente a los objetos, entre sus funciones en el culto de Judá, y el culto fenicio, excepto en el nombre del dios nacional.

Concluye el arqueólogo israelita que el culto es muy común en Jerusalem y en el resto de Judá en este periodo hasta la destrucción de la monarquía.

No se puede dudar que en la interpretación del culto hebreo y de los restantes pueblos de Palestina las aportaciones de la arqueología son fundamentales; es imposible prescindir de ellas.

Los textos bíblicos confirman las afirmaciones de E. Stern. El culto a Baal lo adoptaron los israelitas, según numerosas citas de la Biblia ${ }^{63}$, al igual que a su consorte Astarté 64 . De Acab, rey de Israel, afirma el texto sagrado que sirvió y se posternó ante Baal. Edificó un altar en la Casa de Baal en Samaría. Hizo también una Aserah $^{65}$. En la corta había 450 profetas de Baal, que debieron llegar con su esposa Jezabel, hija de Etbal, rey de Sidón. Contra estos profetas lucho Elías: les retó a un sacrificio, les venció y les degolló. El sacrificio efectuado por los profetas

63 Ju. 2.11; 3.7; 6.25.30; 9.4; 10.6; 1Sam. 7.3; 1Re. 16.31;18.19; 19.18; 22.54; 2Re. 10.18-20; 17.16; 23.4; 2Cro. 34.4; Jer. 2.23; 7.9; 11.13; 19-5; 23.13; Os. 2.13; 11.2; 13.1; Sof. 1.4.

64 Ju. $2.13 ; 10.6 ; 1$ Sam. $7.4 ; 12.10$

65 1Re. 16.31-33. 
y por Elías era muy parecido. El ritual de los profetas fenicios consistía en invocar todo el día el nombre de Baal, en saltar en torno al altar y en cortarse con cuchillos y lancetas hasta chorrear sangre. Los 450 profetas comían de la mesa de Jezabe ${ }^{66}$. Salomón, ya viejo, veneró a Astarté, diosa de los sidonios; también veneró a Milcana, dios de los ammonitas; edificó en la montaña delante de Jerusalem, un lugar excelso consagrado a Carmos, dios de Moab. Sus mujeres extranjeras, en estos lugares de culto quemaban perfumes y sacrificaban a sus dioses. Los ejemplos se podrían multiplicar.

V. Karageorghis ${ }^{67}$, de La fundación G. Anastasios G. Leventis de Nicosia, estudia el culto a Astarté en Chipre, desde la prehistoria al final de la Antigüedad. El simbolismo de la idea de fertilidad comenzó en el Calcolítico en el IV milenio a.C. Aparecen ya figuras femeninas, frecuentemente embarazadas o dando a luz, sosteniéndose los pechos o tocándose el pubis. Los materiales empleados en estas imágenes suele ser terracota o piedra. No se está totalmente seguro si durante el calcolítico surgió la idea de la existencia de una deidad. Esto parece probable en la primitiva edad del Bronce Medio y seguro en el Bronce Final, cuando aparece frecuentemente una dama desnuda con niño. No se han descubierto santuarios fechados en este primer periodo. Se conocen pocos datos sobre el culto, pues los pocos santuarios conocidos apenas nos proporcionan información.

A partir de finales de la Edad del Bronce la situación cambió. Existen santuarios rurales en este periodo. Uno se excavó en Ayios Lacovos, datado en la primera etapa del Bronce Final, pero pudo ser un simple cercado sin rituales. Verdaderos templos aparecieron a partir del 1200 a.C. En Enkomi existían templos dedicados a un dios masculino de la fertilidad, simbolizado por el toro. En Palaepaphos y en Kition, hubo templos consagrados a una diosa de la fertilidad. Pocos símbolos se conocen que indiquen que se trata de una deidad que recibía culto. V. Karageorghis sospecha que se trata de una diosa. En Kition y en Palaepaphos, en los templos aparecen cuernos de consagración, un símbolo religioso de origen cretense, pero no puede ser prueba definitiva de la existencia de una deidad masculina. Cuernos de consagración se documentan también en un lugar de culto como Myrtou-Pigadhes, próximo a la costa noroeste.

Los santuarios de los primeros periodos pueden ser lugares de culto para venerar dioses masculinos y femeninos, o mejor para dioses de la fecundidad caracterizados por símbolos funerarios y masculinos. Al final de la Edad del Bronce parece que se trataba de dioses diferentes, pero se ignoran sus nombres. En los dos principales templos de Enkomi se colocaron estatuas de los dioses. Un varón lleva un casco con cuernos, y otro bronce de un hombre está colocado de pie, sobre la base de un lingote.

66 1Re. 18.19; 22-40.

67 KarageORghis, V. 2003: «The cults of Astarte in Ciprus», en DeVer W. G., Gitin S. (eds) 2003, op. Cit., 215-221 


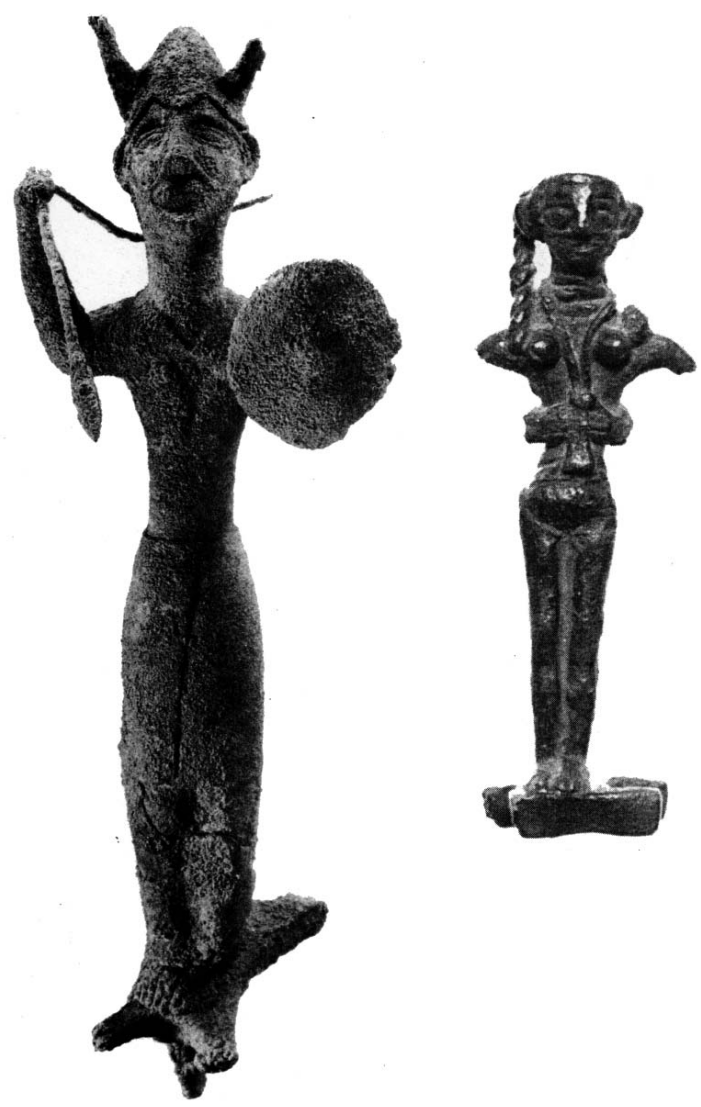

Figura 6: Estatuas de bronce representando a un dios sobre lingote. A. Dios del Lingote de Enkomi. $B$. Astarté desnuda sobre lingote del Ashmolean Museum de Oxford.

La economía y la sociedad de la isla, basada en la explotación del cobre y de la agricultura, puede condicionar la iconografía y el carácter de los símbolos. En Enkomi, los dos principales lugares de culto están vinculados con calaveras de bueyes, posiblemente utilizadas como máscaras en los rituales religiosos. Al mismo tiempo hay estatuas de culto de dioses antropomorfos, como un dios con cuernos, dios de pastores y de campesinos, y un dios con lingote, las bases de la economía chipriota: agricultura, ganadería y minas. Una diosa aparece asociada a la producción del cobre; se la representa como una dama desnuda, tocándose los pechos, de pie, sobre un soporte en forma de un lingote, haciendo pareja con el dios del lingote. Ambos dioses se veneran en el mismo santuario y en habitaciones de culto separadas para el dios y para la diosa. Puede tratarse de un fenómeno posterior.

Piensa Karageorghis que las élites masculinas, que se dedicaban a la producción y explotación del cobre, pudieron preferir poner su riqueza y poder bajo la 
protección de un dios. Se ha sugerido que el dios con el lingote podía representar al protector de las minas de cobre de Chipre, y la diosa podía simbolizar la fertilidad de las minas de cobre. La deidad masculina era el dios de los pastores y de los agricultores, conocido como Apolo Keraeates o Apolo Alasiotas, que podía estar influenciado por los colonos llegados del Egeo a Chipre, principalmente de Arcadia, mientras la concepción y la iconografía tenía sus raíces en la isla.

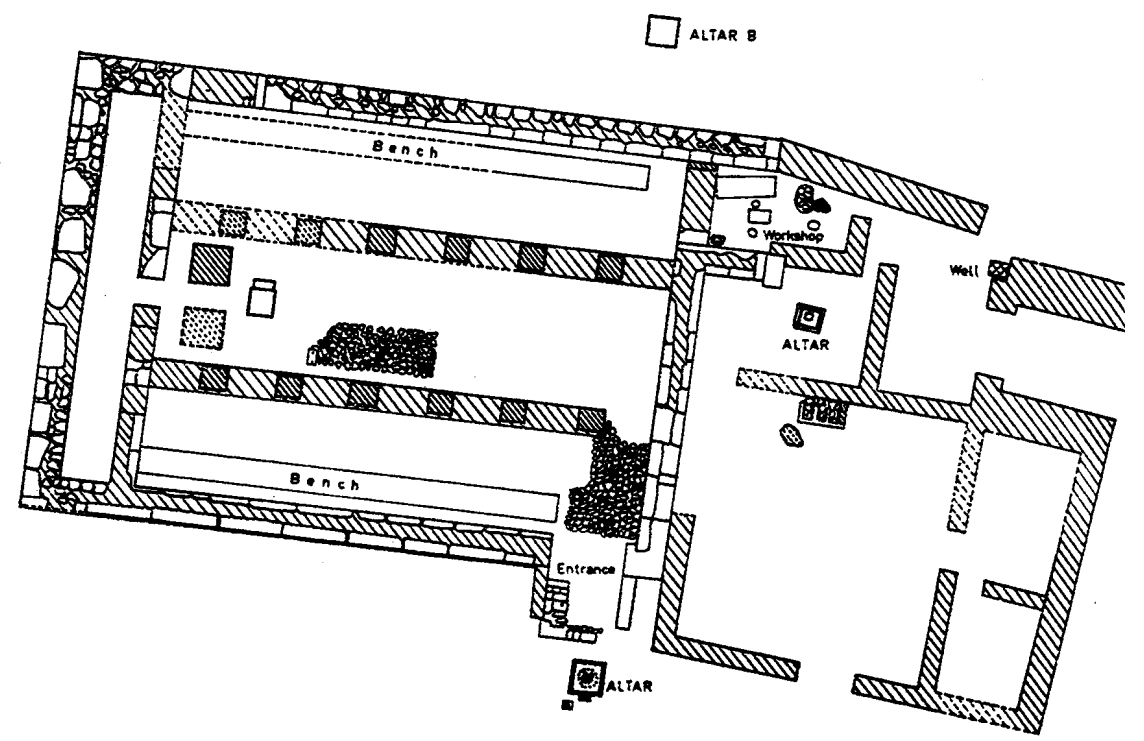

Figura 7: Plano de un templo de Astarté.

El culto al dios con lingote podía también albergar una deidad femenina en la primera mitad del siglo XI a.C., a juzgar por las terracotas masculinas y femeninas encontradas en la isla. Las terracotas femeninas acusan una fuerte influencia de Creta. Las características, además de los brazos levantados, son, la tiara de la cabeza, las manchas en las mejillas, los ojos saltones y un largo collar con pendiente al cuello. Su parecido con las imágenes de la diosa cretense en muy fuerte.

Durante la Edad del Bronce se conocen pocos detalles del culto a los dioses y diosas en Chipre. Karageorghis cree que la diosa con los brazos levantados fue aceptada universalmente. Su cuerpo cilíndrico, como en las piezas de Amathus, datadas en el siglo XI a.C., y otras fechadas en los siglos VIII-VII a.C., mantienen la tradición chipriota, que favorece a la desnudez de la diosa. Los chipriotas adoptan la diosa cretense y aceptan la diosa desnuda de la fertilidad.

Las primeras diosas desnudas con los brazos levantados se encuentran en las placas de la tumba 417 de Lapithos, de finales del siglo XII a.C. En opinión de Karageorghis, este tipo puede ser una adaptación de la diosa cretense, pero igualmente podía ser una variante iconográfica del tipo sirio del Bronce Final. Las placas 
decoradas con figuras femeninas continuaron apareciendo en las tumbas de los periodos chipro-geométrico y chipro-arcaico I, en lugares que luego fueron célebres por el culto a Astarté, como Amathus, Palaepaphos y Tamassos.

En dos repisas de la pared decorada en estilo de la cerámica bicrome III, datadas en torno al 800 a.C., la diosa en relieve, desnuda, pero con la actitud y los rasgos de la cara de la diosa cretense, va asociada a un prótomo de toro, símbolo de la fertilidad. Otras veces la diosa con los brazos levantados, sosteniendo culebras, símbolo de religioso de Chipre, se relaciona con la idea de fertilidad y de muerte. En un disco de bronce de la tumba 79 de Salamina, datado aproximadamente en torno al 700 a.C., la diosa desnuda se representa como Potnia Theron, detrás de dos leones y sosteniendo leones en sus manos. El león fue el animal favorito de la diosa de la fecundidad, como lo prueban los leones de Cibeles y de Ishtar. Frecuentemente el león se asocia a la diosa Hator. Ishtar es la protectora de los caballos. Figuras femeninas desnudas con los brazos levantados se encuentran en dos pequeñas cajas de caliza del periodo Chipro-geométrico III.

Karageorghis es de la opinión que, aunque no se conoce el nombre de esta diosa de la fecundidad, es probable que el cambio radical que experimentó, acuse influjos fenicios.

Los fenicios, a finales del siglo Ix a.C., llegaron a Kition y levantaron un gran templo sobre las ruinas del abandonado templo de finales de la Edad del Bronce. Dedicaron el templo a Astarté, que en tiempos del rey Ethbaal llegó a ser la diosa oficial, cuyo culto llevaron a todos los lugares que colonizaron.

Es claro el influjo fenicio en el templo I de Kition, como indica la epigrafía. El texto fenicio escrito sobre un cuenco de cerámica roja, hallado en el más antiguo piso del templo, quemado poco después del 800 a.C., menciona a un fenicio que fue a Kition desde Tamassos. En el templo de Astarté de Kitión ofreció un sacrificio por él y por su familia; se cortó el cabello, lo colocó en un cuenco y lo dedicó a Astarté.

El mismo ritual se pudo repetir en el monumental templo de Astarté de Palaepaphos. El tipo de la diosa cretense se mantuvo hasta el siglo VIII a.C., como se desprende de las figurillas de terracota con los brazos levantados. Otras influencias de fecha posterior acusan influjos levantinos. Una lleva un anillo en la nariz. En la región de Palaepaphos persistió el tipo de diosa cretense con tiara en la cabeza y con los brazos levantados.

La influencia levantina y fenicia en el culto de Palaepaphos, incluso fuera de los límites del gran templo, es bien conocida por las escultores, que trabajaban hacia el 499 a.C. Se conserva un naiskos de tipo fenicio. Una inscripción del siglo III a.C., hallada en el gran templo, la llama Astarté Paphia. El epíteto se lee en la Odisea, que cuenta las aventuras de Afrodita en el Monte Olimpo, cuando fue sorprendida en un asunto amoroso con el dios de la Guerra, Ares y marchó avergonzada a Pafos donde tenía un templo dedicado y un altar. Homero se refiere al templo de fi- 
nales de la Edad del Bronce, construido hacia 1200 a.C., o quizá el poeta conoció el templo posterior, famoso en todo el Mediterráneo oriental. Homero debió asociar el templo a objetos orientales, como tronos de marfil, camas. Vasos de plata de artesanos sidonios, etc. Los griegos la llamaron Paphia o Kypris; para los chipriotas era sólo Wanassa (Señora).

Para Hesiodo la diosa poseía numerosas características del Próximo Oriente. Es hija de un dios del cielo, como lo fue la diosa del Próximo Oriente Ishtar.

Se conoce poco del culto de la gran diosa de Amathus. Ya en el periodo de 850-750 a.C., en compañía de la diosa de los brazos levantados, como se la representa en placas de oro repujado, se encuentra la cabeza de la diosa egipcia Hator, con seguridad traída por los fenicios de Egipto.

El culto a Hator se mantuvo en Amathus durante los siglos vII-v a.C. Se ha sugerido que en nombre de esta diosa en origen fue Amat, según indica la arqueología.

Los habitantes de Amathus, además de a esta diosa, veneraban a un dios con cuernos, no distinto del dios egipcio Bes, cuya iconografía es numerosa en el periodo tardío de Amathus.

El vaso gigantesco de piedra, hallado en la cumbre de la acrópolis de Amathus, fechado en el siglo VII a.C., con seguridad fue vinculado con los rituales de la diosa de la fecundidad. Servía para las purificaciones lustrales, como el famoso Mar de Bronce del templo de Salomón.

En Amathus se ha hallado un trono sostenido por esfinges a cada lado, que obedece a un prototipo fenicio asociado a Astarté. En el santuario de Ayia Irini se ha encontrado una terracota que representa a una dama entronizada entre esfinges. Un trono también se descubrió en la tumba 79 de Salamina de Chipre, así mismo decorado con esfinges. Diosas desnudas sosteniendo los pechos son bien conocidas en la coroplástica de Chipre del siglo vi a.C., en túmulos de Amathus. Parece que son la supervivencia de la diosa con los brazos levantados.

En el sarcófago, posiblemente regio, de Amathus, fechado a comienzos del siglo $v$ a.C., la diosa está representada en compañía de Bes. El carácter fúnebre de la diosa chipriota desnuda, procede también del Próximo Oriente. Se relaciona con Inanna o Ishtar, que desciende a los infiernos para renacer de la muerte. En el mundo infernal de este modo ejerce su poder, como diosa de la fertilidad y de la regeneración, del mismo modo que en vida fue la sagrada prostituta la diosa de la fertilidad. En tumbas de la necrópolis de Amathus, numerosas terracotas representan la diosa tocándose los pechos o vestida. Los devotos están frecuentemente representados en terracotas, tocando la pandereta o la lira. Otro símbolo de la diosa, principalmente en Amathus, con un naiskos de arcilla en miniatura, con la imagen de la diosa dentro de él; es la media luna, bien conocida en el Próximo Oriente, como símbolo de Astarté. 


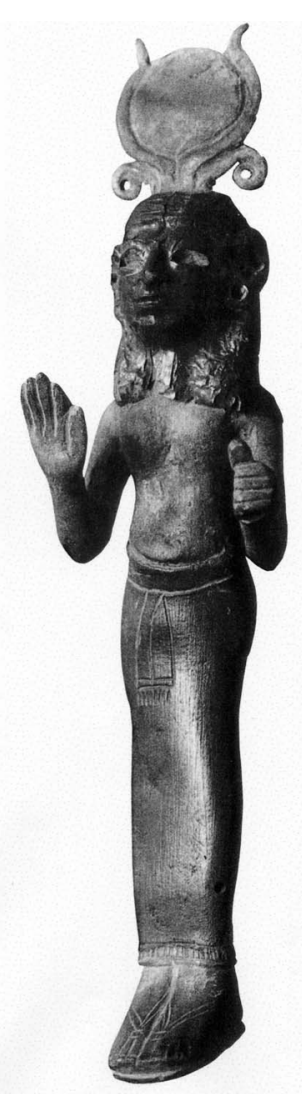

Figura 8: Astarté siria con signos astrales. Palestina

Los fenicios introdujeron el culto de Astarté, como lo prueba no sólo la iconografía, sino las fuentes escritas. Heródoto ${ }^{68}$ escribe que el culto de Afrodita-Astarté, se introdujo en Chipre desde Ashkelon. Pausanias ${ }^{69}$ escribe que el culto a Afrodita comenzó con los asirios, y después fue adoptado por los pafios y los fenicios de Ashkelon. Heródoto ${ }^{70}$, afirma que la prostitución sagrada en Chipre procedía de Babilonia. Algunos otros datos importantes es posible recordar, sacados de otros trabajos de Karageorghis y que completan los anteriores ${ }^{71}$, como el ritual de cortarse el cabello y ofrecerlo a la diosa, que se repetía un milenio después en Hierápolis; antes de casarse los muchachos y las muchachas iban al templo, se recortaban los cabellos, los depositaban en un vaso de oro o plata, que colgaban en

68 I.105.2-3.

69 I.14.7.

70 I.199.1-5.

71 KaRAgeorghis, V. 1981: Ancient Cyprus. 7000 Years of Art and Archaeology. Londres. Louisiana State University, 45, fig. 31; 150-151, figs. 115-116. KARAGEORGHIS, V. 1976: Mycenaean and Phoenician Discoveries in Cyprus. Londres, Thames \& Hudson, 107-117. 
el templo e inscribían sus nombres encima. Luciano informa que él, de joven, cumplió este ritual, y colocó el cabello en un cuenco con su nombre inscrito y lo depositó en el templo; añade ${ }^{72}$ que cuando un hombre va por ver primera como devoto a Hierápolis, se corta su sabello, sacrifica un cordero, se arrodilla y coloca la cabeza y los pies del animal sobre su cabeza y pide a los dioses acepten su sacrificio. Una inscripción realizada sobre una pequeña placa de mármol, hallada en la acrópolis de Kition, datada en el siglo Iv a.C., enumera las varias categorías de personas adscritas al templo y sus emolumentos, entre las que se mencionan los barberos sagrados, además de sirvientes, escribas y prostitutas sagradas.

El rey de los sidonios y de los tirios Ethbaal (887-856 a.C.), antes de ser rey fue sumo sacerdote de Astarté ${ }^{73}$. Siendo rey instituyó su culto oficialmente. El templo de Kition podía haber sido levantado por Ethbaal, como templo consagrado a Astarté, al pertenecer Kition a su reino. El templo dedicado a Afrodita era, quizá, tan importante como el famosísimo templo de Afrodita de Pafos, que se construyó al mismo tiempo que el de Kition y estuvo abierto al culto 1000 años. La fecha del templo está representada en las monedas romanas de Pafos. Tiene tres entradas que conducen al santa santorum, con tres columnas exentas a cada lado de la entrada central, como en Kition. Delante del santa santorum hay un antro. Las tres columnas exentas recuerdan a las dos columnas de bronce del templo de Salomón ${ }^{74}$, que se encontraban en el mismo sitio del templo. Estas columnas se documentan también en el templo de Arad, en los templos de Melqart de Tiro y de Cádiz y en el modelo de arcilla del santuario de Idalion, en Chipre. En el santa santorum del templo I de Kition, que tenía tres entradas, probablemente había una imagen de la divinidad y de dos acompañantes.

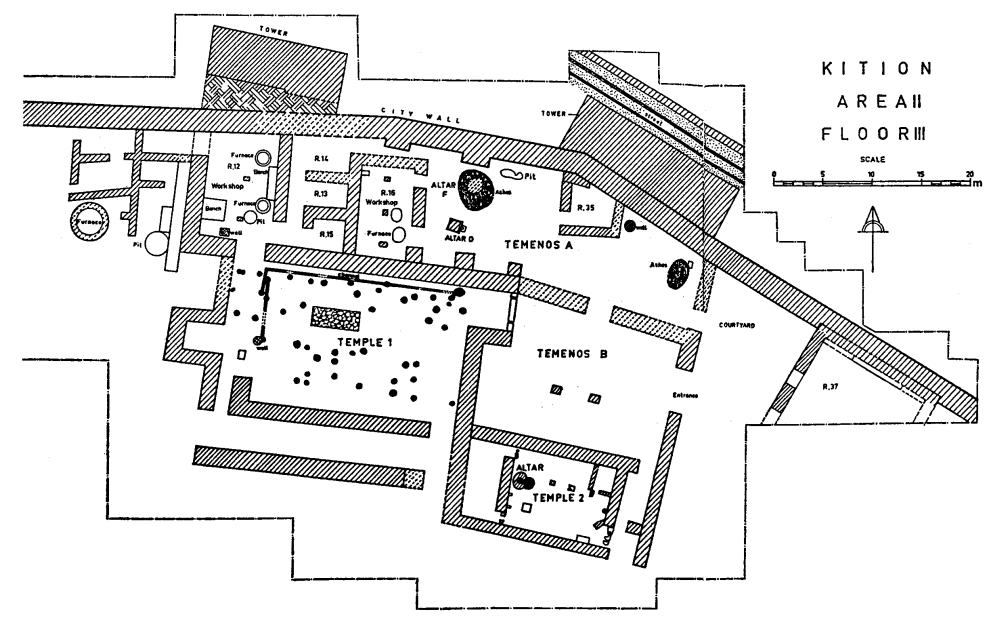

Figura 9: Templo de Chipre de finales del siglo XIII a.C.

72 Dea Syria, 60.

73 Bormet, C. 1976: Astarté. Consiglio Nazionale delle Richerche. Roma.

74 1Re. 7.15-22; Je. 52.21.23. 
La prostitución sagrada era un ritual típico de los cultos fenicios y se extendió por todo el Mediterráneo. Prostitución sagrada hubo en el templo babilonio de Militta ${ }^{75}$. En los santuarios fenicios se daba la prostitución tanto masculina como femenina. Prostitución sagrada se documenta en Chipre ${ }^{76}$, en los templos de Astarté en Pafos, de Amathonte y de Kition. Luciano de Samosata ${ }^{77}$ menciona el templo de Afrodita de Biblos; Eusebio de Cesaréa ${ }^{78}$ alude a la prostitución masculina y femenina en los santuarios de Astarté de Agqa y de Baalbek hasta el siglo Iv. También está atestiguada en el templo de Afrodita de Eryx ${ }^{79}$, en el puerto de Tarquinia en Etruria y en el santuario de Cancho Roano en Badajoz; al igual que en Cartago y en Sicia Veneria ${ }^{80}$. Las danzas de las bailarinas gaditanas, en origen, debían ser bailes sagrados en honor de Astarté que se desacralizan y se convierten en juego ${ }^{81}$. Las danzas eran uno de los rituales más fundamentales del culto a Astarté, representados en las páteras fenicias, como en la hallada en la Cueva de Zeus (750-700 a.C.) del Monte Ida; de Idalion (850-750 a.C.); de Curion (710-675 a.C.); de Olimpia (750-700 a.C.); de Esparta (750-700 a.C.); de procedencia desconocida, hoy en el Iran Bastan Museum de Teherán (850-750 a.C.) y del Cleveland Museum, también de procedencia desconocida (710-675 a.C. $)^{82}$.

En la ánfora Hubbard del Cyprus Museum de Nicosia, en marfiles y en una pixide del Palacio de Nimrud, generalmente participan músicos tocando diferentes instrumentos musicales, a veces acompañados de danzarinas cogidas de la mano. En alguna pieza sólo se representan bailarinas. La procesión se dirige a una dama entronizada que debe ser Astarté delante de una mesa. La mujer desnuda entre leones que decora un escudo hallado en la Gruta del Ida, datado en el siglo vill a.C., es obra fenicia y, probablemente representa a Astarté. Sigue la misma iconografía que una astarté de atalaje de caballo hallado en la tumba 79 de Salamina de Chipre, fechado a finales del siglo VIII a.C.

En el ánfora Hubbard, fechada a finales del siglo VIII a.C. o a comienzos del siguiente, detrás del trono se pintó una esfinge. Las bailarinas se cogen por la mano. Interviene en la procesión alguna vez un músico. En la mesa delante de la diosa hay jarras y una mujer ofrece ofrendas. Detrás de esta última hay un prótomo de toro. Entre los judíos igualmente existían danzas de jóvenes y de mujeres para celebrar los prósperos acontecimientos del pueblo ${ }^{83}$ y en solemnidades religiosas ${ }^{84}$. David saltó y bailó delante del Arca de Yahweh ${ }^{85}$. El salmista insta al pueblo a alabar a Dios con danzas ${ }^{86}$.

75 Heródoto 1.199.

${ }^{76}$ Clemente de Alejandría, Protr. 2.1.4; lust. XVIII.5.4.

7 Dea Syria, 6.

78 V. Const. 111.55 .58$.

9 Diodoro, IV.83.4; Estrabón, VI,2,6.

Valerio Máximo II.6.15.

${ }^{31}$ Marcial I,41.12; III, 63; V, 78; VI,71,2, XIV, 203; Juvenal, XI,162.

32 Markoe, G. 1951: Phoenician Bronce and Silver Bowls. University de California. California, passim.

33 Ex. 15.20; JU. 11.34; 1Sam. 18.6.

${ }^{34}$ 2Sam. 6.5; 14.16;

35 2Sanm. 6.16.

86 Sal. 149.3; 150.4 . 
En el santuario de Meniko, dedicado a Baal-Hammón han aparecido dos quema incienso fechados en el siglo vi a.C. Consisten en un soporte circular coronado por un cuenco. El nombre de Baal-Hammon significa «dios del altar perfumado». En los sellos está el dios entronizado delante de un quema incienso. En el culto hebreo se quemaba incienso ${ }^{87}$ igualmente en grandes cantidades.

En el templo I de Kition se han encontrado dos modelos de santuarios en arcilla ${ }^{88}$ fechados en el último periodo del templo, poco antes del año 1000 a.C. En Megiddo ha aparecido un modelo de terracota de santuario datado entre los años 1000-800 a.C., de planta cuadrangular, con ventanas circulares y con esfinges en los cuatro lados. Un segundo modelo de santuario se halló en Beth-Shan, datado en el siglo XI a.C.. Tiene dos cuerpos rectangulares superpuestos, con ventanas también rectangulares. En la parte superior se encontró una figura humana de pie, desnuda, con dos pájaros. En la parte inferior hay dos ventanas con una serpiente entre ellas. Son un tipo de modelos de templo diferente de los griegos, como los ejemplares de arte submicénico (1100-1000 a.C.) de Arcanes, del Herarion de Argos (700 a.C.) y de Perachora, Corinto (700 a.C.).

En Megiddo se encontró un objeto cilíndrico con cuenco para quemar incienso en la parte superior y dos aberturas cuadradas en el cuerpo, fechado entre los años 1150-1100 a.C., y en Beth-Shan un objeto de culto cilíndrico, datado en el siglo XI a.C., con serpientes y pájaros.

En una tumba de Amathus, fechada en el periodo Chipro-Arcaico II, un varon cubre su cabeza con una máscara de toro. Esta costumbre se remonta, en Chipre, a los finales de la Edad del Bronce, como lo prueba el modelo de santuario en arcilla depositado en una tumba del cementerio de Vounous, donde tres devotos cubren su cabeza con máscaras de toro y llevan serpiente en las manos. Las cabezas de toro las usaban los sacerdotes o los devotos, que poniéndoselas adquirían las cualidades del toro, símbolo de la fertilidad y de la virilidad.

Bucraneos han aparecido en los santuarios de la Edad del Bronce de Enkomi y de Kition. El influjo de la religión fenicia fue muy fuerte en la religión judía.

William Dever, profesor de Arqueología y antropología del Próximo Oriente de la Universidad de Arizona, conoce la Biblia a la perfección por haber dirigido muchas escavaciones en los lugares biblicos. Se enzarzó en un apasionante debate sobre la historicidad de los libros sagrados con I. Filkenstein ${ }^{89}$. Últimamente ha publicado otro volumen cuyas teorías recogemos,

El rey del Éxodo no puede ser Thutmosis III, que realizó campañas anuales en Canaán y subió al trono hacia 1446 a.C., fecha que se considera como aproximativa del Éxodo, sino Ramsés II (1290-1223 a.C.), que reinó dos siglos más tarde.

87 Ex. 90.7.6; Lev. 2.1-2.16.

88 SPITERIS, T. 1970: Art de Cypre des origines a l'epoque romaine. París. Editions du Cercle d'Art, 159.

89 DeVer, W. G. 2002: op. cit. 
Para construir las villas de Pitom y Ramsés ${ }^{90}$ el soberano redujo a la esclavitud a los hebreos. La villa ha sido identificada de modo concluyente con Avaris, antigua capital de los Hicsos. Fue destruida por los egipcios en 1530 a.C., y abandonada durante casi la totalidad del Imperio Nuevo. La ciudad no conserva huellas de edificios ni de campamentos de esclavos. La ciencia no ofrece explicación aceptable a las plagas de Egipto. La travesía del Sinaí va unida a un cuadro ideal: el censo de la población israelita; la revelación de Yahweh en el Monte Sinaí; el decálogo; la alianza entre Yahewh e Israel, suplantando a la antigua deidad cananea El; la peregrinación por el desierto bajo la protección de Yahweh; la construcción del tabernáculo; la organización del sacerdocio y del culto; la fidelidad vacilante de Israel; el castigo de una generación, contraria a acampar 38 años en el oasis de CadesBarné; la renovación de los promesas; la delimitación de las fronteras y las construcciones para la conquista de Canaán ${ }^{91}$.

El censo es fantástico pues da una población de 600.550 personas $^{92}$. La legislación sacerdotal es muy compleja y refleja el culto institucional, ligado posteriormente a la monarquía. El oasis de Cadés no conoció ninguna ocupación anterior a la monarquía. No se ha detectado ninguna ruta del Éxodo en el Sinaí. El siglo XIII a.C., se estima que corresponde mejor al Éxodo ${ }^{93}$.

La ocupación de Edóm para penetrar en Transjordania, no pudo ser tal como la relata la Biblia, pues el nomadismo prevaleció en la región hasta el siglo VII a.C. Ningún rey de Edóm pudo oponerse, pues, a los israelitas. Edóm es estado a partir del siglo VIII a.C. La destrucción de Arad, antes de las ciudades vecinas ${ }^{94}$, no tiene fundamento histórico. Jesbón ${ }^{95}$ no posee vestigios importantes del siglo XIII a.C. La campaña moabita no debió tener lugar. La descripción de la Biblia responde al contexto del siglo vII a.C.

Madián no fue ocupada de manera extensiva más que a partir de los siglos VIIIVII a.C. Fue conquistada por los asirios a mediados del siglo VIII a.C. La sumisión de los cinco reyes madianitas no tiene apoyatura arqueológica. Tel el-Umeiri, en las afueras de Amán, sería la única ciudad transjordana que podría dar pruebas arqueológicas de una ocupación israelita, pero no las ha dado ${ }^{96}$.

Estudia Dever, a continuación, la conquista al oeste del Jordán ${ }^{97}$. La saga nacionalista que tiene por protagonista a Josué se fecha, probablemente, en el reino de Josías (640-609 a.C.). Las matanzas que hizo Josué carecen de fundamento histórico. Numerosos sabios han rechazado la historicidad en bloque del Libro de Josué. Se ha defendido un modelo de conquista propuesto por W. F. Albright, el

\footnotetext{
90 Ex. 1.11.

91 Ex. 15-20; Le. 1-24; Nu. 1-36.

92 Nu. 1.20-41.

93 Dever, W. G. 2002: op. cit. 15-30.

$94 \mathrm{Nu}$ 21.2-3.

$95 \mathrm{Nu}$. 21.21-32.

96 Dever, W. G. 2002: op. cit. 31-44.

97 DeVer, W. G. 2002: op. cit. 45-84.
} 
padre de la arqueología bíblica desde 1920 hasta 1971, fecha de su muerte y seguido por otros. Los trabajos llevados a cabo en Bethel, Debir y Hazor parecían corroborar una vasta invasión armada de pueblos extranjeros que penetraron en Canaán a final del siglo XIII a.C., o los comienzos del XII, pero no hay pruebas de destrucción de Jesbón en Transjordania. La destrucción de Jericó, con base arqueológica, se fecha alrededor del 1500 a.C., y está en función de las campañas de los egipcios durante la dinastía XVIII para arrojar a los Hicsos. Jericó, a mediados del siglo XIII a.C., fecha del Éxodo, se encontraba en el más absoluto abandono. No hay huellas de ocupación durante el Bronce Reciente II. La conquista de Jericó Carece de base histórica. Así, entre el 1500 y comienzos del siglo XII a.C., estaba abandonada. A finales del siglo XIII a.C., en época de la conquista israelita, era una ruina. Albright suponía que el recinto bíblico de Ai, en realidad se refería a Bethel, a 2 kilómetros de distancia, pero las ruinas de Ai es un serio revés a la teoría de la conquista. De Gabaón no hay huellas de conquista a final del siglo XIII a.C. Nada hay anterior al siglo VIII a.C. Debir, que se sitúa en Khirbet Rabud, no tiene huellas de destrucción entre los siglos XIII-XII a.C.

Hazor era la capital de las ciudades estado del Bronce Reciente. Una segunda teoría, contraria al modelo anterior, sería la infiltración pacífica. Las tradiciones bíblicas describen los antepasados de Israel como pastores nómadas viviendo en tiendas. Las gentes, que pueblan las altas tierras de Canaán, la Palestina Occidental de los siglos XIII-XII a.C., descenderían de las tribus nómadas de las regiones semiáridas de Transjordania. Sería una infiltración pacífica que concordaría bien con los recuerdos bíblicos de Israel, de origen tribal y nómada, con una estancia en Transjordania antes de penetrar en Canaán, con una transformación gradual a una sociedad agro-pastoril con ideales igualitarios. La hipótesis de una sedentarización gradual y pacífica de nómadas, es contraria a la tradición bíblica, Los amoritas se sedentarizaron, pero los textos de Mari y de otros lugares indican un proceso que duró medio siglo.

Se ha pensado, también, en una revolución interna, motivada por razones religiosas. Los primitivos israelitas serían indígenas o locales. Campesinos cananeos locales de finales de la Edad del Bronce o comienzos del Hierro, revueltos contra la aristocracia corrompida, fundaron una nueva entidad étnica social. Los primeros israelitas serían cananeos excluidos por la geografía y la ideología. La arqueología pulveriza la tesis del establecimiento de los israelitas al oeste del Jodán, en Canaán. W.G. Dever, menciona una lista larga de ciudades. Las huellas de ocupación sedentaria en Transjordania meridional en el Bonce Reciente Cananeo al comienzo del Hierro, son raras. En el siglo vII a.C., los ammonitas, los moabitas o los edomitas comenzaron a unirse en estados-ciudades y es muy probable que fueran víctimas de las destrucciones de los siglos XIII-XII a.C., excepto Tell el-Uneiri.

Según el arqueólogo norteamericano, la arqueología no apoya la teoría de una masiva invasión militar israelita en Canaán. Una parte de las narraciones de las 
conquistas bíblicas son ficciones literarias tardías, lo que no indica que toda la historia de Israel sea una ficción, como pretenden muchos revisionistas. El modelo de infiltración pacífico se apoya en una teoría etnográfica equivocada. La teoría de la revuelta campesina da, por ver primera, importancia a las poblaciones autóctonas de los primeros israelitas.

Dever ${ }^{98}$ pasa a estudiar la región de las colinas centrales, el corazón del antiguo Israel: Raddama, Tel Masos, Giloh, Izbet Sartah, Silo, Khirbet el-Dawara, Beersheba, etc., excavada a partir del año 1970, fechadas entre los siglos XIII-XII a.C.

Es importante fijarse en un lugar de culto del siglo XII a.C., con características únicas sobre el Monte Ebal, sobre la altura que domina Sichem. Allí se ha descubierto un altar; la primera fase data de finales del siglo XIII a.C. En la fase siguiente hay una pequeña construcción rectangular, sin entrada aparente, orientada a los cuatro puntos cardinales. En el interior se recogieron multitud de huesos de animales, y en los dos patios adyacentes se hallaron muchas jarras conteniendo fragmentos de cerámica, cenizas, huesos calcinados de carneros, de ciervos, de bóvidos y de corzos. Se ha interpretado la construcción central como un gran altar, al que se llega por una rampa escalonada. Los huesos calcinados recuerdan el holocausto de la Biblia. Se ha reconstruido a partir de la descripción del altar de Ezequiel. Esta interpretación, en general, no ha sido aceptada. Se ha pensado que podía tratarse más bien de una torre de vigilancia.

A continuación Dever pasa a examinar las recientes excavaciones ${ }^{99}$, que la Biblia hebrea identifica como israelitas. Hay un gran número de testimonios, principalmente en la orilla occidental del Jordán, en el corazón del antiguo Israel. En los siglos XII-XI a.C., la región de las colinas de Canaán sufrió una verdadera explosión demográfica. La mayoría de estas villas pertenecen al periodo premonárquico. No están situadas ni en las llanuras de Sharón y de Judá, ni en las tierras bajas de Shefelah, ni en los valles de los principales ríos. Casi todas se fundaron ex novo y no sobre las ruinas de ciudades destruidas durante el Bronce Reciente. Se llevó a cabo, por tanto, una colonización, de una región montañosa casi despoblada. Los nuevos colonos de las tierras altas, intentaban evitar un choque militar. Son pequeñas villas con una extensión que nunca supera las 2,5 Ha. No poseían carácter urbano. Ocupan la parte alta de un monte en valles fértiles, adecuados para la producción de cereales, con terrazas para el cultivo del olivo, la vid, las legumbres y los árboles frutales. Las estepas próximas ofrecen buenos pastos. Sobre la cultura material, Dever ${ }^{100}$ da precisiones muy importantes.

La forma de la casa no tiene antecedentes en Canaán, aparece en los siglos XII-XI a.C. Responde a una sociedad agropastoril. Se agrupan dos o tres casas de estas, con muros medianos y patios comunes, que podían ser un recinto familiar.

98 DeVer, W. G. 2002: op. cit. 85-100.

99 DeVer, W. G. 2002: op. cit. 101-112.

100 DeVer, W. G. 2002: op. cit. 145-166. 
Producían cereales como trigo y cebada, legumbres, hierbas y plantas. Adaptaron nuevas técnicas del cultivo. Los huesos de animales indican que entre el 45 y el $80 \%$ de los animales criados eran ovejas y cabras. También se han recogido huesos de ganado vacuno y de asnos. Un patio con pilares servía de establo. Falta el cerdo, que se documenta en los lugares del Bronce y en los sitios costeros del Hierro, que se atribuyen a los filisteos.

Ciertas instalaciones ocupaban el fondo de las casas. El resto tenía grandes jarras. Cultivaban aceite de oliva, vino, cereales y uvas frescas y secas. Hay silos y cisternas colectivas. Se ha encontrado todo tipo de útiles. La producción era de carácter familiar. Había talleres para fabricar instrumentos de piedra o de sílex, cerámica, prensas de aceite o de vino.

Las características económicas pueden calificarse de rurales, familiares, agropecuarias, comunitarias y, quizá, igualitarias. La sociedad debía ser tribal.

Los utensilios de hierro fueron introducidos gradualmente a lo largo de los siglos XII-XI a.C., y sólo se generalizaron en el siglo x a.C. Las técnicas de fabricación de cerámica difieren de las del Hierro I. Los alfareros del Hierro I utilizaban menos el torno. Los repertorios cerámicos son del Bronce Reciente. Hay una ausencia casi total de cerámicas importadas. En cambio, en las ciudades cananeas abundan las cerámicas importadas de Chipre y de Grecia continental.

Para Dever, el mejor indicio del origen de los colonos del Hierro I en las zonas ocupadas, es su tipo de cerámica. La continuidad cerámica prueba que los colonos han salido de la sociedad cananea del Bronce Reciente.

Se documenta la ausencia de un arte israelita indígena. Durante la monarquía, siglos $x$-VII a.C., se detecta una tradición artística muy rica, con aportaciones de Fenicia y de otros lugares. Desaparecen las ricas tradiciones artísticas del Bronce Reciente. No se han descubierto cementerios. Una gran gruta funeraria, no publicada aún, fechada entre los siglos XIII-XII a.C., se ha descubierto en Dothan. No se conoce nada vinculado con la religión o el culto. Con el Bronce Reciente desaparecen los templos de la sociedad cananea. Un templo o santuario del Hierro I es el sitio donde apareció el toro de Mazan. El toro de bronce puede representar el toro de El.

Algunos poemas, como las Bendiciones de Jacob ${ }^{101}$, el Canto de la mario2 o el Cántico de Debora ${ }^{103}$, que se ha supuesto que se remontan a los siglos XII-XI a.C., no se pusieron por escrito hasta los siglos VIII-VI a.C. La religión del primitivo Israel no se puede calificar de monoteísta ni de única.

El dios Yahweh aparece en un texto egipcio del siglo XIII a.C., asociado a los nómadas shosou, trashumantes en Transjordania meridional, donde algunos textos bíblicos sitúan el origen de su culto.

\footnotetext{
101 Ge. 49.

102 Ex. 15.

103 Ju. 5.
} 
Dever pasa a continuación a examinar las tentativas precedentes de síntesis, deducidas de los textos y de la arqueología, sobre el primitivo Israel. Para Kaufmann la religión de Israel era una creación original diferente radicalmente de todo lo conocido por el paganismo. Esta interpretación hoy está abandonada. Nortr interpreta las doce tribus como las anfictionías helenísticas; esta teoría, hoy, también está pasada de moda. Weippert creyó que los ancestros de los israelitas eran los nómadas del Bronce Medio y Reciente, comparables a los beduinos actuales. Combate la ecuación apirou=hebreos. Holper se opone al modelo de conquista. Acepta la tradición de la invasión israelita. Defiende que la narración del Éxodo tipológicamente es verídica. Chaney rechaza el modelo de la conquista y de la invasión pacífica. Propone el modelo de revuelta campesina, que corresponde a los datos del archivo de Amarna, a la arqueología sirio-palestina y a la tradición bíblica. Coote y Whitelam creen que el estudio de la historia de Israel es tan complejo que exige la cooperación de especialistas en numerosas disciplinas, lo cual es totalmente verdad. Coote defiende el modelo de simbiosis defendido por numerosos arqueólogos. Para Ahlström el término Israel no designa un grupo étnico particular, sino una región geográfica, la región de las colinas de Canaán. Valora la mención de Israel en la Estela de meneptah, hacia 1210 a.C. La población de las tierras altas se califican más tarde de israelitas. Serían originarias de las tierras bajas de Canaán, desplazadas por los trastornos del final de la Edad del Bronce. Podían haber participado algunos apirou. Descarta calificar de Israel a algunas poblaciones antes de la monarquía, siglo $x$ a.C. J.A. Soggin propone que la historia de Israel no es anterior al siglo x a.C., con la monarquía unida. Miller es partidario de que Israel, a los comienzos, debía ser una vaga confederación de tribus y de clanes, que emergen gradualmente de la población primitiva del país. Los ancestros de los israelitas tendrían orígenes diferentes. Parecen haber emergido de las tierras cananeas a comienzos de la Edad del Hierro. La cultura material era esencialmente cananea. Todos estos autores son los primeros de la ciencia bíblica sobre Israel.

Los revisionistas opinan que es imposible escribir la historia del Antiguo Israel, por lo menos a partir de los textos bíblicos.

David propone tres Israel: el Israel histórico de los pueblos de Palestina de la Edad del Hierro.; el Israel bíblico o literario y el antiguo Israel inventado por los modernos a partir de los dos primeros. Los dos últimos Israel son una construcción social, una ficción. La única fuente posible sería la arqueología, pero sus limitaciones no lo permiten. Para Whitelman, los sabios modernos, principalmente los cristianos fundamentalistas y los sionistas israelitas, han inventado su propio Israel. Los palestinos serían los verdaderos nativos de la región. El problema es la identidad de los palestinos. Lemche es partidario de una tesis radical: la Biblia hebrea se habría compuesto, casi enteramente, en el siglo II a.C. Es una obra de propaganda piadosa, resultado de la crisis de identidad de los judíos que vivían en Palestina. Para Thompson Israel se reduce a un pequeño feudo de las tierras altas, desde el norte de Jerusalem al sur del valle de Jezreel. Yahweh no tiene que ver gran cosa con la concepción bíblica de Dios. 
Es interesante la opinión de los arqueólogos israelitas y americanos. Para Lapp, la arqueología de las ciudades del litoral y del valle de Jezreel testimonian la probabilidad de una destrucción sistemática de casi todas las ciudades importantes durante la segunda mitad del siglo XIII a.C. Ningún arqueólogo importante aventuraría esta declaración. B. Mazar considera la conquista de Israel como un proceso complejo y dinámico. El Israel primitivo sería la amalgama de muchos grupos étnicos diferentes. Yadin se apoya en sus excavaciones ya mencionadas. Aharoni defiende el proceso de infiltración. A lo largo de la sedentarización, los israelitas habían destruido algunos lugares de las colinas sobre el Jordán. Las teorías de Aharoni están hoy olvidadas. Fritz es partidario del modelo de simbiosis. Callaway da importancia a la arqueología para reconstruir la historia de Israel. Los pioneros de la región de las colinas rechazaban las guerras y las violencias. Buscaban un abrigo a los conflictos de las llanuras más fértiles. Estas aldeas del Hierro I de las tierras más altas, prueban que los habitantes participaban de los movimientos generales de población que afectaban a todas las tierras de Canaán. Kochavi insiste en las diferencias regionales y sobre el proceso de poblamiento. El movimiento va de este a oeste y serían los pastores nómadas los que se sedentarizaron.

Mazar defiende que la cultura material israelita difiere sensiblemente de la cultura Cananea. La distribución de los habitats, el plan y su localización, la composición de la cerámica, la estructura económica y social, no son cananeas.

L.E. Stager pone el acento en la divinidad regional de las aldeas del Hierro I. Piensa que es muy simple atribuir todo solo a israelitas de la tradición bíblica. Se opone a la teoría del nomadismo. Ni los campesinos, ni los nómadas del Bronce Reciente cananeo podían proporcionar suficientes individuos para justificar la explosión de la población en las colonias del Hierro I.

Bunimovitz acepta que los pastores nómadas colonizasen la región de las colinas. Strebing rechaza la teoría de una sedentarización de los nómadas. Cree que debió producirse un éxodo de dimensiones reducidas. Llega a una conclusión sorprendente: la mayor parte de las poblaciones que forman Israel vinieron de alguna región oscura del Mediterráneo huyendo de la sequía que agotó estas regiones entre los siglos XIII-X a.C. Esta última teoría de la sequía es inventada. Redford rechaza todas las teorías sobre los orígenes de Israel. Los primitivos israelitas eran un contingente de nómadas shosou, que vivían en el Canaán meridional, conocidos por los archivos egipcios de las dinastías XVIII y XIX, que los sitúan en las fronteras de Moab, de Edom y de Negev. En los archivos egipcios los shosou son pastores nómadas que se desplazan en función de los pastos y se dedicaron al bandolerismo. Muchos textos mencionan a un dios de nombre Yhw en el país de Shosou. Estos textos son la mención más antigua del Yahweh israelita que la Biblia sitúa en el país de Madian. Algunos biblistas y arqueólogos, siguiendo a Redford, asocian los shosou a los presentes israelitas. 
Willian Dever ${ }^{104}$ propone una nueva síntesis sobre los orígenes y sobre la naturaleza del Israel primitivo. El arqueólogo norteamericano coincide con I. Finkelstein y con la mayoría de los arqueólogos en los siguientes puntos:

1. Los viejos modelos están obsoletos. Las conclusiones de la arqueología prevalecen sobre las de la Biblia.

2. Las prospecciones arqueológicas y las excavaciones ofrecen enseñanzas cruciales.

3. En el Hierro I hay un crecimiento de población, principalmente en las colinas.

4. Los colonos de las tierras altas no eran invasores extranjeros. La mayoría procedía de la sociedad cananea.

5. La colonización se desarrolla progresivamente.

6. La cultura material del Bronce Reciente continuó durante el Hierro I y II.

7. La cultura del siglo XII a.C., no es homogénea. Es mezcla étnica.

8. La tecnología y el medio ambiente desempeñan un papel clave.

Difieren Dever y Finkelstein en otra serie de puntos que son reseñables:

1. Sobre los orígenes de Canaán Finkelstein es partidario de la sedentarización, Dever de una población diversificada compuesta por pastores nómadas y por sedentarios procedentes de las tierras bajas.

2. Según el arqueólogo israelita la colonización se data a finales del siglo XII a.C., según Dever comienza en el siglo XIII a.C.

3. A Dever le parece más evidente que a Finkelstein la continuidad de la cerámica del Bronce Reciente. La introducción de nuevas técnicas, como las terrazas y las cisternas son más importantes para Dever que para Finkelstein.

4. La introducción de estas nuevas técnicas son mucho más importantes de lo que opina Finkelstein.

5. Dever da más importancia a los factores sociológicos e ideológicos. Finkelstein es más materialista y determinista.

6. Finkelstein es más incapaz de identificar a los colonos de las tierras altas. Dever los califica de protoisraelitas.

W.G. Dever ${ }^{105}$ propone nuevas síntesis sobre el primitivo Israel, como un movimiento fronterizo de reforma agraria. Dever, para defender que los colonos del 
Hierro I eran sedentarios, se basa en las tierras bajas de Canaán, ya en los centros urbanos, ya en los campos, empleando los siguientes argumentos:

1. Los colonos de las zonas fronterizas de las colinas debían tener una experiencia como agricultores en Canaán. Los nómadas habrían sido incapaces de fundar una sociedad desarrollada y una agricultura.

2. La razón de la colonización se encuentra en las condiciones miserables del interior de Canaán.

Dever insiste en la naturaleza heterogénea de la población cananea del Bronce Reciente. Estos colonos estaban marginados en la sociedad, huían de la explotación económica y de una burocracia ineficaz y corrompida. También participaban apirou y otras bandas rebeldes que vivían la resistencia y se entregaban al pillaje; desertores y mercenarios sin sueldo y aventureros; refugiados; gentes huidas de la justicia egipcia; campesinos arruinados; aldeanos desplazados y pastores.

La tradición bíblica menciona a los amoritas, a los cananeos, a los jebuseos, a los perizzitas, a los neohititas y a otros. Los gabaonitas y los sichemitas fueron admitidos en la confederación israelita después de firmar un tratado.

El nomadismo bíblico es más una nostalgia tardía que una realidad:

1. Dever piensa que la población de Canaán en el paso del Bronce Reciente al comienzo del Hierro I era más movil.

2. La cultura material prueba una gran unidad social, familiar y de clan. Los peligros de frontera pudieron reforzar esta tendencia.

3. La región de las colonias corresponde a la región donde los marginados y desplazados, que podían encontrar refugio contra la represión de las autoridades urbanas.

4. La sociedad, altamente politizada de la Canaán del Bronce Reciente, evidente en los textos y en la arqueología, ofrece un ejemplo perfecto de esta separación.

Muchos investigadores han rechazado el modelo de revuelta campesina. La Biblia no tiene huellas de este conflicto, que tampoco ha dejado rastros arqueológicos. El arqueólogo norteamericano refuta estas objeciones:

1. Las sociedades antiguas estaban continuamente desgarradas por revueltas campesinas.

2. La tradición bíblica tiene conocimiento de una guerra campesina de liberación. Se apoya en una revuelta contra la aristocracia que oprimía al campesinado, documentada en los primeros asesinatos de los reyes cananeos; 
en la reticencia de Samuel a nombrar un rey, que pondría al pueblo a su servicio, que le privaría de libertad y de sus posesiones ${ }^{106}$; en las condenas de Isaías ${ }^{107}$ contra los depredadores; en la arremetida de Miqueas ${ }^{108}$ contra los que se apoderan de los campos. La justicia social de la Bíblia casi siempre va vinculada con la posesión de las tierras. Esta tradición es antigua y única.

2. Sólo una revuelta social puede explicar un inmigración importante.

Dever piensa que una reforma agraria debió ser el motor y el objetivo del movimiento israelita. Este fenómeno no fue único. Recuerda el arqueólogo americano que algunos investigadores, principalmente arqueólogos, son menos escépticos que Finkelstein, insistiendo en la heterogeneidad de las poblaciones del Hierro I, que no podían ser calificados de israelitas y no es necesario confundir los colonos de las colonias con el Israel bíblico. No puede hablarse del verdadero Israel antes de la monarquía, siglo x a.C. ${ }^{109}$ Su existencia se documentaría, por vez primera, en los textos neoasirios y en la inscripción de Tel Dan del siglo IC a.C., y, después, por los textos bíblicos redactados en el siglo vIII a.C.

Los habitantes de las colinas no formaban un estado llamado Israel. No se les puede llamar israelitas. Eran los ancestros directos y auténticos de los posteriores israelitas de la Biblia. Se les podría llamar. Según Dever, protoisraelitas por tres razones. Un desarrollo cultural no se impone de la noche a la mañana, es necesario mucho tiempo de maduración. La continuidad de la cultura material entre el Hierro I y el Hierro II, periodo de la monarquía absoluta y la mención de Israel en la Estela de Meneptah. El Israel bíblico desciende de los protoisraelitas. En el siglo x a.C., parece que un gran número de asentamientos comienzan a ser abandonados y se establecieron nuevas aldeas:

1. Hay un cambio gradual de la ruralidad al urbanismo. En el siglo $x$ a.C., Dan, Hazor, Beth-Shean, Megiddo y Tanak son poderosas ciudades fortificadas de carácter israelita. En el centro Tirça, Sichem, Beth-Shémesh, Tell Bert Mirsim y Beersheba continúan. Importantes centros urbanos son tambiénLaquish y Samaria.

2. La población de las tierras altas se triplica, de 55.000 se pasó a 150.000 en el siglo vII a.C. Es el crecimiento de una población estable.

3. Continúa la técnica de terrazas y cisternas que se multiplican. Se documentan labores hidraúlicas que se hacen más complejas en Hazor, Megiddo, Gabaón, Jerusalem y Gézer

\footnotetext{
106 1Sam. 8.

107 Is. 5.8 .

108 Mi. 22.

109 DeVER, W. G. 2002: op. cit. 212-244.
} 
4. Se generaliza la casa de pilares en el atrio hasta finales de la monarquía en las zonas rurales y en las urbanas.

5. Las pequeñas granjas familiares se convierten en complejos agroindustriales.

6. Emerge el estado israelita como proceso natural con sucesión dinástica frecuentemente criticada, burocratización, una sociedad altamente estratificada, una economía centralizada y unas ambiciones internacionales. Los profetas hacen una crítica despiadada de la situación ${ }^{110}$.

7. Aparecen unos estilos artísticos más refinados. Amós menciona los lechos de marfil que serán destruidos.

A partir de la monarquía se conocen numerosas tumbas y santuarios privados, templos locales, el templo de Jerusalem y objetos de culto, altares, mesas de ofrenda, templos en miniatura, vasos sagrados, imágenes de Asherah y una clase sacerdotal. Bajo la monarquía se seguía venerando a Baal, a El, a Asherah. Un aspecto fundamental de la religión cananea e israelita bajo la monarquía fue la fertilidad. El sistema de sacrificio israelita remonta al culto cananeo. El calendario litúrgico es de origen cananeo y agrícola. Israel adoptó las antiguas fiestas cananeas de la recolección del otoño y del año nuevo.

El hebreo de la Biblia y de las inscripciones desciende de un dialecto cananeo. Los poemas del Pentateuco y algunos salmos están próximos a la poesía y a las narraciones cananeas datadas en los siglos XIV y XIII a.C. halladas en Ugarit.

Dever estudia la mención de Israel en la Estela de Meneptah. Concretamente afirma que Israel es devastado, no existe más su simiente. Se menciona Tehessu, Libia, Halti, Ios Hititas; Yanoám se identifica con una importante ciudad de Canaán, posiblemente el-Abeidiyeh. Son conocidas las ciudades Ashqelon y de Geza. Hurru son los Hurritas, en Siria, durante el Bronce Reciente. La estela menciona a los pueblos vencidos por Egipto que han sido pacificados. Ashqelón, Gezer, Yanoam son ciudades estado de Canaán. Israel es el equivalente a un pueblo, a un grupo étnico. La lectura final es que el pueblo israelita es devastado. Esta fase ha recibido distintas interpretaciones. Whitelam indica que la estela no aporta gran cosa sobre la localización del antiguo Israel. La estela expresa una percepción del pasado. Para Lemche la inscripción testimonia la existencia de una identidad étnica, que lleva el nombre de Israel a finales del siglo XIII a.C. Estaría este Israel al norte de Canaán, o en las altas tierras centrales. El Israel de la estela no correspondería exactamente al Israel bíblico. Para Kitchen, al contrario de Ahlström, el Israel de Meneptah representaría más una región geográfica que un pueblo. Según Thompson en Israel de Meneptah, ni es el Israel de las altas tierras, ni tampoco el Israel bíblico. Los términos de Canaán e Israel son parientes metafóricos de las tres villas

110 Am. 6.4-7. 
destruidas por los egipcios: Ashqelón, Gezer y Yanoam. También ha sugerido que el escriba había inventado por azar la palabra Israel.

Para Finkelstein la referencia a Israel en la estela es muy vaga. Dever sostiene que Meneptah conoce la existencia de Israel y que está en Canaán. No se refería al valle de Jezreel, ni a Galilea, ni al Neguev, ni a Transjordania meridional. El Israel de Meneptah se sitúa en las colinas centrales. El arqueólogo norteamericano concluye:

1. En 1210 existió en Canaán una entidad cultural y política llamada Israel, conocida en Egipto.

2. Israel era una posible amenaza a la hegemonía egipcia.

3. Israel no estaba organizado administrativamente como otros estados de Canaán. Era una asociación libre de pueblos, unidos en un grupo étnico.

4. El territorio de Israel no se encontraba en las tierras bajas.

Piensa Dever que la mención de Israel en la Estela de Meneptah confirmaría la existencia de protoisraelitas en las altas tierras de Canaán en el Hierro I. Estos protoisraelitas no eran israelitas por entero sino ciudadanos del Estado de Israel. Una representación pictórica de Karnak se ha interpretado como figuras de israelitas. En otros relieves también se ha realizado la misma interpretación.

Dever se plantea el problema de si todos los colonos de la región de las colinas eran protoisraelitas. Hay pocos testimonios de la penetración israelita en Galilea que se encontraba bajo la influencia fenicia durante mucho tiempo.

Herzog concluye que la colonización israelita responde a un proceso complejo de cambio socio-económico, que afectó a la mayor parte de las regiones de Canaán, que comenzó a finales del siglo XIII a.C. La mayor parte de las regiones cultivadas fueron ocupadas por pequeños grupos de origen étnico y sociológico heterogéneos. La consolidación de la identidad nacional y étnica llamada Israel, alcanzó su apogeo con la monarquía unida. La identidad étnica ha durado un siglo, desde finales del siglo XI a.C., a finales del siglo x a.C. Termina con la división de la monarquía unida.

Según la tradición bíblica, Jerusalem fue de los jebuseos, hasta que cayó en manos de David a comienzos del siglo $x$ a.C. ${ }^{111}$ Se ignora quienes eran los jebuseos. Se propone que era un clan cananeo local. La jerusalem del interior de las murallas no ha sido excavada. Pocas huellas de la ciudad del Hierro I y menos del siglo $x$ a.C., se han encontrado. Se ha negado que fuera una ciudad de cierta importancia, y menos aún la capital de un estado con anterioridad al siglo VIII a.C. Al norte y oeste de Jerusalem, las prospecciones israelitas han descubierto unos 30

111 2Sam. 5.6-10. 
pequeños establecimientos del Hierro I. La población que vivía alrededor de Jerusalem, en tiempos del Hierro I, se ha estimado en 2.200 personas.

El panorama general de Palestina comprendía:

- Los centros que se dividían la antigua cañada e incluían arameos de Siria y del norte de Canaán.

- Fenicios asentados en el norte del litoral.

- Filisteos y pueblos del mar afincados a lo largo del litotral central y meridional.

- Protoisraelitas.

- Estados de Transjordania: Amón, Moab y Edóm.

La fuente bíblica, redactada, probablemente, hacia el siglo VIII a.C., se refiere a todo Israel, que dominaba todo Canaán, desde antiguo. Dicho así, esta afirmación es inexacta. Existía una diversidad cultural y étnica en Canaán en el periodo del Hierro.

Los cananeos eran las poblaciones indígenas de Canaán en la Edad del Bronce y a comienzos del Hierro. Eran pueblos semitas occidentales y ocupaban el Líbano meridional y litoral, Israel, Cisjordania y Jordania. Canaán aparece en los textos a partir del 1500 a.C.

- Los amoritas son semitas occidentales. Eran pastores nómadas. Su nombre aparece por vez primera a finales del III milenio. Se pueden asimilar a los cananeos.

- Los hititas eran indoeuropeos y fundaron un imperio en Anatolia y en el sur de Siria, durante el segundo milenio hasta finales de la Edad del Bronce, hacia 1200 a.C. Nunca penetraron en Canaán. Los hititas bíblicos son los neohititas.

- Los perizzitas habitaban las villas no fortificadas. Se les asocia a lugares como Sichem y Bethel.

- Los hirvitas son de origen desconocido.

- Los luvitas pueden ser los habitantes trogloditas de la primitiva Canaán. No eran semitas. Se asentaron en el norte de Siria y de Mesopotamia. Emigraron al sur de Canaán a partir del 1500 a.C. Los patronímicos luvitas aparecen en los nombres de los reyes cananeos, citados en la correspondencia de Amarna.

- De los jebuseos se ignora casi todo.

- Los amelecitas son descendientes del hermano desheredado de Esaú. Se asocian a Edóm en Transjordania meridional. 
- Los filisteos son parte de los pueblos del mar a los que combatió Ramses III hacia 1180 a.C. Aparecen en el Génesis, Josué y Jueces como rivales de los primeros israelitas. Filisteas fueron las ciudades de Gat, Eqron, Ashdod y Ashqelón. Estaban confinados entre la costa y las faldas de las colinas. Se relacionaron poco con los primitivos israelitas.

Canaán fue poblado por diferentes pueblos durante el Hierro I. Estos pueblos han justificado las descripciones israelitas de la conquista.

Termina Dever ${ }^{112}$ examinando si la tradición bíblica es mito o realidad, tema que es de gran importancia. Piensa este autor que la arqueología es la fuente primordial. Se plantea tres problemas: Si la Biblia no es historia, ¿en qué es creíble?; si las naciones bíblicas no son históricas ¿por qué aparecen en la redacción del texto?; ¿Por qué las conservan y transmiten como fundamento de una tradición tenida por válida hasta hoy? Antes de responder a estos temas propone tres aproximaciones que permiten evaluar, a los compiladores, a los autores y a los editores de la Biblia en tanto que historiadores.

1. Sus fuentes orales o escritas antiguas o contemporáneas eran adecuadas. Cuentan la historia tal y como se desarrolló. Si esto fue así, su competencia sería la de cualquier Historia Antigua. Este método es el tradicional seguido por los autores bíblicos.

2. Los autores y editores bíblicos disponían de algunas fuentes fiables, que manipulan, mezclan sus propias ficciones, para ajustar la narración a su programa ideológico. Si ello fue así, los autores creen que han comunicado la verdad de la época. Se podría hablar de mito historiográfico. Así es como la ciencia moderna, liberal y crítica, considera la Biblia.

3. Según la tercera posibilidad, las fuentes auténticas de los autores de la Biblia son inexistentes. Son todas inventadas.

La posición de Dever es la segunda. Piensa que las tradiciones del antiguo Israel contenidas en el Exodo, Números, y Josué hasta Reyes no corresponden a criterios que les permitían ser históricos, pero contienen algunas informaciones históricas que son fiables.

Los libros del Éxodo y Números que narran la estancia en el desierto y conquista de Transjordania, chocan con los testimonios arqueológicos. No contienen casi nada de historia. La conquista y ocupación de Canaán, descrita en Josué y Jueces son pura ficción. No ha existido la conquista total de Canaán. Piensa Dever que el Libro de los Jueces responde a tradiciones orales o escritas más antiguas y más auténticas que el Libro de Josué. La fe y el destino de Israel se fundaron en la promesa a los patriarcas en la liberación de la esclavitud, en la salida de Egipto, en

112 Dever, W. G. 2002: op. cit. 245. 
la travesía por el desierto, en la conquista de Canaán, en el don de la tierra prometida y en la herencia eterna de Israel.

El arqueólogo norteamericano interpreta el Éxodo como un mito, o mejor como una metáfora para una liberación. El Éxodo no son sólo unas líneas dedicadas a la justicia, es la historia del triunfo último del espíritu humano. Desde antiguo el Éxodo fue interpretado como una metáfora. Es un símbolo universal e intemporal.

Dever presta especial interés a la figura de Moisés, que es clave en la Biblia. La reconstrucción de este autor de los orígenes de Israel es poco convincente para muchos modernos. Contradice los temas teológicos fundamentales de tradiciones literarias de la Biblia. Los motivos criticados son los siguientes:

1. La milagrosa liberación de las tribus israelitas del yugo agrupadas bajo Moisés.

2. La permanencia en el desierto y la revelación de la Ley, los diez mandamientos en el Sinaí.

3. La Alianza de Yahweh con el pueblo elegido y el don de la tierra prometida.

4. La conquista de Canaán y la repartición del país, ofrecido en herencia a las 12 tribus.

Estos acontecimientos representan los fundamentos de la época israelita en el Antiguo y en el Nuevo Testamento. Son parte integrante del patrimonio espiritual de las comunidades judía y cristiana y de la tradición cultural de Occidente.

Es fundamental, como dice el arqueólogo americano, conocer si las narraciones bíblicas son parte de historia, mitos, hechos o fantasías. Los arqueólogos tienen tendencia a despreciar las cuestiones religiosas. Para Freud, Moisés fue inventado por necesidad del subconsciente humano. Dever está tentado de reconciliar, si es posible, el Moisés mítico de los textos, con una posible personalidad histórica. El problema planteado es ¿cómo explicar las tradiciones de Moises, si ellas pertenecen a una literatura tardía y si no tienen algunos fundamentos históricos? ¿Cómo se transmitieron oralmente durante cinco o seis siglos? Los revisionistas piensan que Moisés y la Ley, son mitos sobre el origen, creados en siglo II a.C., y el sin fundamento histórico.

Se está enfrentando a muchas objeciones históricas. No existe ninguna prueba exterior de la Biblia, ni texto alguno ni dato arqueológico sobre la existencia de Moisés. Los milagros de Moisés desbordan la credibilidad del hombre moderno, incluso del más crédulo. No es convincente la aparición repentina de una nueva religión revolucionaria, sin un proceso de preparación.

La trilogía Sinaí-Moisés-Alianza es muy difícil de aceptar para un moderno. Hay otras cuestiones pendientes. 
La mención más antigua del Éxodo se lee en el canto de la mar113 y no menciona a Moisés. La plegaria más antigua ${ }^{114}$ no cita a Moisés en relación con la liberación de los egipcios. Fuera del Éxodo y de los Números, Moisés ocupa un puesto inferior. En la literatura anterior al destierro de Babilonia, sólo los profetas Jeremías ${ }^{115}$ y Miqueas ${ }^{116}$ le mencionan. Moisés no ocupa un lugar destacado más que en el Deuteronomio y en la epopeya que va de Josué a los Reyes, compuesta bajo el reino de Josías, hacia finales del siglo VII a.C. Aquí Moisés aparece como fundador y legislador de la religión israelita. Estos materiales sirven a la propaganda nacionalista. Los investigadores sospechan la existencia de un manuscrito de un sermón perdido de Moises, descubierto en los archivos del templo de Jerusalem ${ }^{117}$, como sucedió con el Deuteronomio que se había encontrado en los mismos archivos.

El Moisés bíblico sería una invención literaria tardía. Se ha señalado que las dos versiones de los diez mandamientos ${ }^{118}$, parecen no tener relación alguna con el Pentateuco. Debían circular desde hacía mucho tiempo versiones de los diez mandamientos. En la forma actual no se datan con anterioridad al siglo VIII a.C. Es una fantasía atribuirlos a un Moisés del siglo XIII a.C. Sin embargo, debió existir un fundador de la religión israelita.

Dever recoge algunos datos sobre un contexto importante, como la posibilidad de que asiáticos hubieran podido huir de la servidumbre egipcia. Se conocen textos egipcios bien fechados en el Bronce Tardío, que mencionan un dios Yahweh entre los nómadas de Transjordania. En la tierra de Madian el suegro, según la Biblia, introdujo a Moisés en el culto a esta deidad. Numerosos textos bíblicos describen a Yahweh como saliendo de Seir, del sur de Edóm ${ }^{119}$. Incluso algunos investigadores de los más radicales, consideran la posibilidad de que algunos shosou pudieran formar parte de las poblaciones tribales, que participaron en el Israel primitivo, después de haber sido guiados por el desierto por un jefe carismático llamado con un nombre egipcio, Moisés.

Estos mitos preisraelitas habrían sobrevivido hasta el final de la monarquía. Serían incorporados en la saga nacional, que emergió en el momento en el que el viejo Israel agrario cedió paso a la urbanización.

Termina Dever recogiendo las últimas encontradas teorías. Los arqueólogos palestinos afirman que los cananeos que ocupaban la región durante el Bronce Antiguo, en el III milenio, eran los ancestros directos de los palestinos. Se ha presentado también la tesis indígena de la aparición de Israel, por parte judía. Lo que había era un cierto número de pueblos antepasados de los israelitas y de los palestinos.

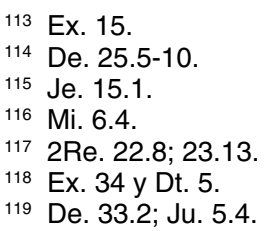

